\title{
Regional Migration, Insurance and Economic Shocks: Evidence from Nicaragua
}

\author{
Teresa Molina Millán*
}

November 9, 2014

\begin{abstract}
In developing countries, the large majority of migrants move inside their own countries or to neighboring regions, yet there is limited evidence on whether internal migrants represent a source of insurance for their household of origin or vice-versa. To test whether transfers sent and received by migrants serve an insurance role, this paper estimates the causal impact of income shocks at a migrant's origin and destination on the transfer of funds. Rainfall shocks in rural Nicaragua are found to lead to changes in income but not in food consumption, indicating that households are able to smooth consumption. I find that migrants between the ages of 15 and 21 years old provide unilateral insurance to their origin household. Distinguishing by destination and economic activity I show that the level of insurance increases when migrants and households are exposed to less correlated rainfall shocks. In addition, I find evidence of bilateral insurance among selected groups of migrants, that is migrants with non-agricultural income and rural migrants exposed to rainfall shocks with low levels of correlation with respect to shocks occurring at origin. These results provide evidence of co-insurance arrangements among household members geographically spread inside a country.
\end{abstract}

JEL Code: O12, O15, F24, D1

Keywords: Internal migration, remittances, risk, insurance, inter-households transfers, weather shocks

\section{Introduction}

Rural households in developing countries are exposed to many kinds of risk. In a contexts characterized by limited access to credit and insurance markets, households have developed a range of different strategies to cope with and manage adverse economic shocks (Rosenzweig and Wolpin, 1993; Morduch,

${ }^{*}$ Ph.D. Candidate, Paris School of Economics. E-mail: teresa.molina@psemail.eu. I am grateful to Karen Macours for her excellent guidance and her insightful suggestions on this project. I am very thankful to Tania Barham for hosting me at the Institute of Behavioral Studies at the University of Colorado and to Thomas W. Dickinson for all his support and assistance in GIS. I will also like to thank Tania Barham, John Maluccio, Hillel Rapoport, Luc Behaghel and participants at Northeast Universities Development Conference 2014, Oxford University Development Workshop, and at the Paris School of Economics workshops for their comments and suggestions. I gratefully acknowledge the financial support of the Inter American Development Bank, Initiative for International Impact Evaluation (3ie: OW2.216), and National Science Foundation (SES 11239945 and 1123993) for data collection and preparation. All errors are my own. Financial support from DIMeco Ile-de-France is also gratefully acknowledge. 
1995; De Weerdt and Dercon, 2006). But most of these strategies offer little protection in case of weather shocks as they affect almost everybody in a local area. Meanwhile, climate change is forecast to increase adverse weather events in developing countries and therefore households' exposure to covariate shocks (WorldBank, 2013). In order to handle local common shocks, households may rely on a network of relatives extended beyond the borders of their community or village. The spatial mobility of household members across regions exposed to different shocks creates favorable conditions for the development of informal risk-sharing arrangements.

In this paper, I investigate whether the transfer of funds between permanent migrants and their origin households has an insurance role in rural Nicaragua. While most of the recent literature has focused on the insurance role of remittances from international migrants, this paper looks at internal and regional migration. International migration is expensive and risky, and is more frequent among individuals who have wealthier backgrounds and more education. Regional and domestic migration is much more common among poor households in rural areas, with household members moving to close and distant locations for work or family reasons. Focusing on this type of migration, this paper investigates not only whether internal and regional migrants provide insurance to their origin household, but also whether they receive insurance from it. I refer to this reciprocal relationship as co-insurance.

Information on migrants' location allows me to simultaneously examine exogenous income shocks at origin and at destination and to look at the efficiency of the insurance mechanism at different levels of income correlation. I use a two-agent risk-sharing model to show that the transfer of funds between both agents is a function of income uncertainty at origin and at destination. While risk-pooling will be more efficient when a network's income is less correlated, large distances among network members may increase both information and enforcement cost. I estimate the causal impact of income shocks on transfers from the migrant to the household of origin (henceforth, "remittances") as well as transfers from the origin household to the migrant (henceforth, "transfers").

Under the assumption that migrants and their origin households are risk averse but incur different risks at different times, the New Economics of Labor Migration (NELM) predicts that remittances should be highest when recipients are exposed to income shocks. This hypothesis has been tested in several studies (Lucas and Stark, 1985; De la Briere et al., 2002; Cox et al., 1998; Gubert, 2002), which rely on household data and on regional proxy for the identification of income shocks rather than data on exogenous shocks. ${ }^{1}$ In the last decade, a strand of the new experimental literature on migration has focused on understanding the role of remittances as an instrument to cope with economic shocks. These studies focus on exogenous shocks which have a credible impact on household income to estimate adjustment on the flow of remittances. Clarke and Wallsten (2003) and Yang and Choi (2007) find that international remittances increase when households in the country of origin are exposed to adverse weather events. At the country level, Yang (2008a) compiles further evidence on this insurance mechanism. He finds that for the poorest developing countries hurricanes lead to increases in migrants' remittances, which account for 20 percent of experienced damages.

All these studies have in common that they are focused on how overseas remittances adjust to income shocks at migrants' original community. Few studies look at how remittances are affected

\footnotetext{
${ }^{1}$ See Rapoport and Docquier (2006) for a model on the remittance sending decision and Yang (2011) for a review of the literature on remittances dimensions.
} 
by exogenous shocks at destination. Yang and Martínez (2005) and Yang (2008b) analyze how outcomes in non-migrating household members in Philippines react to different variations of international exchange rates. They find that exogenous increases in migrant resources have positive effects on investment outcomes in the household of origin, suggesting a positive income effect on the amount of remittances sent.

This paper contributes to this literature by looking at a different pool of migrants and by analyzing the presence of co-insurance arrangements between migrants and their origin households. The empirical strategy allows me to break down the net effect of rainfall shocks on the flow of transfers, into an income and an insurance component, and to identify the mechanisms behind the insurance agreement. This paper also relates to De Weerdt and Hirvonen (2013) who examine how income shocks and household consumption co-vary across linked households in Tanzania. They find that internal migrants share about 2.7 percent of their consumption growth by insuring family members at their original location, but they do not find evidence of bilateral insurance. My analysis differs by focusing on the actual flows of transfers between households and migrants, which allows me to understand the mechanism behind the risk-sharing arrangement.

To test the insurance role of transfers I use two rounds of data from a household survey implemented in poor, rural communities in Nicaragua (2000-2010). Rain-fed agriculture is the main income source among non-migrating households, and rainfall deficits during the main growing season negatively affect household income. I exploit local variation in rainfall to analyze how exogenous income shocks affect transfers. Regional migration in this area is important, 50 percent of the households in the original communities have at least one permanent migrant in 2010 and only 2.5 percent of those are international migrants.

I restrict the analysis to young migrants between the ages of 15 and 21 in 2010. This cohort comprises the ages in which important life transitions -finishing school, beginning work, getting married, leaving home- occur in developing countries. The realization of this transition may bring with it some risks and uncertainties which affect the economic relationship with other household members. By focusing on this age cohort I analyze informal arrangements in a sample where all migrants were long-term household members prior to migration. In the dataset I use, migrants of this age group were intensively tracked during the follow-up survey in 2010 and interviewed at their new location. After 10 years, the attrition rate for this group is around 11 percent. To analyze whether the effect varies over the life cycle I use reported information by the origin household on migrant's location between the ages of 22 and 30 .

I analyze the insurance mechanism by estimating the impact of rainfall shocks on the probability to send and receive transfers and on the annual amount of funds transferred. I split the sample of migrants into local and non-local migrants. Local migrants are exposed to the same weather shock as their origin household, while non-local migrants are exposed to different ones (see Section 3). As expected, transfers between local migrants and their origin household do not adjust in face of rainfall shocks. Among non-local migrants, the results provide evidence that young migrants provide unilateral insurance to their households of origin. Remittances are adjusted by shocks at origin but transfer receipts are not adjusted by shocks occurring at destination. This result indicates the presence of unilateral insurance contracts in line with the findings in the literature focused on international remittances. 
I find that remittances received from non-local migrant compensate 24 percent of the reduction in household agricultural income and to 10 percent of the reduction in total household income due to a one standard deviation decrease of accumulated rainfall. This amount is far from full insurance, but it shows the prevalence of informal risk-sharing arrangements beyond the community level.

A key contribution of this paper is to look at how different levels of correlation between income shocks at origin and at destination affect the flow of transfers. Therefore, I look at insurance arrangements by migrants' destination and economic activities.

Considering migrants' destination, I find that while urban migrants unilaterally insure their household of origin, average rural migrants neither provide nor receive such insurance. I show that the lack of insurance among rural migrants is explained by high levels of correlation between shocks at origin and at destination. When the difference between the intensity of rainfall shocks increases, rural migrants provide insurance to their origin household. Moreover, the results show that they also receive insurance from their origin household, although as distance between locations increases the implementation of such an insurance mechanism weakens. This result points to the existence of a co-insurance arrangement, but it also indicates a trade-off between the level of correlation among rainfall shocks and the access to information on migrants' economic situation. I find further evidence of the presence of a co-insurance contract on migrants involved in non-agricultural and agricultural activities. Finally, this paper finds that exogenous reductions in income coming from rainfall shocks at origin reduce transfers receipts by non-local migrants. This income effect on migrants' transfer receipts occurs regardless of migrants' characteristics and destination, suggesting that is not correlated with the insurance mechanism.

This paper contributes to the literature on risk management by highlighting the role of regional and internal migrants on informal insurance arrangements. A strand of this literature has focused on the study of informal insurance by reciprocal transfers and gifts from friends and relatives (Townsend, 1994; Udry, 1994; Fafchamps and Lund, 2003; De Weerdt and Hirvonen, 2013; Jack and Suri, 2014). With the exception of De Weerdt and Hirvonen (2013) and Jack and Suri (2014), this literature has focused on the flow of transfers at the community or village level. It has argued that information and enforcement problems are likely to be small between the members of a community creating an adequate environment. This paper shows that regional migrants and their origin households participate in insurance arrangements in the context of weather shocks. Furthermore, my results suggest the presence of an asymmetric insurance arrangement and a trade-off between the level of correlation of shocks and the access to information on migrant's economic situation.

Understanding of the role of regional migration for insurance against shocks has important implications for policy. Indeed, while there has been significant interest in policies targeting international and seasonal migration, there has been less policy attention to domestic and regional migration. ${ }^{2}$ Recent policy experiments on international migrants have shown that they remit and save more when they have higher control over their bank accounts in their country of origin (Aycinena et al., 2010; Ashraf et al., 2014) or when they face lower monitoring cost over the use of remittances at origin (Batista and Narciso, 2013). Looking at seasonal migrants, Bryan et al. (2014) show that small incentives to seasonal migration lead to an increase in the number of seasonal migrants, to an improvement

\footnotetext{
${ }^{2}$ see McKenzie (2012) for a overview of policy experiments and research designed experiments on determinants of migration self-selection.
} 
in terms of consumption, and to an increased rate of seasonal migrants in the following years. Policies targeting permanent domestic and regional migration have received less attention, with the exception of studies focused on the impact of mobile money on risk-sharing strategies (Blumenstock and Fafchamps, 2013; Jack and Suri, 2014). Jack and Suri (2014) explore the impact of reducing transactions cost on receiving remittances and on consumption smoothing in Kenya. They provide evidence that, while mobile money improves self-insurance as a safe method of saving, the mechanism driving consumption smoothing lies in the increase of domestic remittances received.

The remainder of the paper is set out as follows. Section 2 presents the insurance model from which reduced forms are derived. Section 3 summarizes the data, describes the sample of migrants and the remittance behavior. Section 4 presents the weather shocks. In Section 5, I present the specification strategy, and in Section 6 I discuss the results and the mechanism driving the main results. Section 7 investigates other risk coping mechanisms and Section 8 concludes.

\section{Conceptual Framework}

Among the several motives for why remittances may occur, the literature usually distinguishes four groups: self interest (i.e., inheritance), pure altruism, exchange (i.e., repayment of a intra-family loan) and co-insurance. As Lucas and Stark (1985) point out, remittances may combine any of these, making it difficult to distinguish empirically between different motives. Even if it is difficult to correctly identify the motive behind the decision to remit, it is possible to test whether remittances and transfers among migrants and their household of origin play an insurance role. To do so, I follow the literature on risk sharing and I set up a simple model from which I derive the reduced form equations to test the insurance hypothesis. This section builds on Fafchamps and Lund (2003) and Yang and Choi (2007). ${ }^{3}$

Risk-sharing theory states that if there is a Pareto-efficient allocation of risk across network members, consumption should not be affected by individual income shocks. About 75 percent of original households in my sample have only one migrant in this age cohort, therefore I simplify the risk-sharing model to a two-individuals model. Consider two risk-averse members coming from a former household: the household head $(h)$ who has stayed in the community of origin $(o)$ and a young migrant $(m)$ who was formally a member of the household and is currently living in a different location $(d)$. I assume that all members have identical preferences and that they cannot borrow or save. I take the decision to migrate as a given, and analyze the decisions to send transfers and remittances, conditional on migration by the young adult. The migrant and the household head have a contract with the objective to insure against income risks faced by either of them.

Both individuals are working and able to actively participate in an insurance contract by sending transfers back and forth to each other. Individuals have an uncertain income $y_{s}^{i}$, where $s^{g} \in S$ stands for the state of nature in location $g(g \in G=\{o, d\})$, and $i=\{h, m\}$. They consume $c_{s^{g}}^{i}$ and derive instantaneous utility $U_{i}\left(c_{s^{g}}^{i}\right)$. Utility is separable and it's twice differentiable, with $U_{i}^{\prime}>0$ and $U_{i}^{\prime \prime}<0$. The model can be solved as a simple Social Planner Maximization problem in which a weighted sum of each individual utility is maximized,

\footnotetext{
${ }^{3}$ See also (Mace, 1991; Altonji et al., 1992; Townsend, 1994)
} 


$$
\max _{c_{s^{d}}^{m}, c_{s^{o}}^{h}}\left\{\omega_{m} U\left(c_{s^{d}}^{m}\right)+\omega_{h} U\left(c_{s^{o}}^{h}\right)\right\}
$$

Pareto efficiency requires the ratio of marginal utilities between members to be constant in any state of nature:

$$
\frac{U_{h}^{\prime}\left(c_{s^{o}}^{h}\right)}{U_{m}^{\prime}\left(c_{s^{d}}^{m}\right)}=\frac{U_{h}^{\prime}\left(c_{s^{o^{\prime}}}^{h}\right)}{U_{m}^{\prime}\left(c_{s^{d^{\prime}}}^{m}\right)}=\frac{\omega_{m}}{\omega_{h}}
$$

with the planner's weights $\omega_{i}$ satisfying $0<\omega_{i}<1$ and $\omega_{h}+\omega_{m}=1$. Let individual utility take the form of a constant absolute risk aversion function with all individuals having the same coefficient of absolute risk aversion $\theta$,

$$
U_{i}\left(c_{s^{g}}^{i}\right)=-\frac{1}{\theta} e^{-\theta c_{s}^{i} g}
$$

The first-order conditions for individual i include

$$
\omega_{i} e^{-\theta c_{s}^{i} g}=\lambda
$$

where $\lambda$ is the Lagrange multiplier associated with individual i's resource constraint. Because I am only interested in the flows between two individuals, and $\lambda$ is the same for all individuals, I can equalize the marginal utilities by each individual, then taking logs and rearranging, I get:

$$
\frac{1}{\theta}\left(\ln \omega_{m}-\ln \omega_{h}\right)=c_{s^{d}}^{m}-c_{s^{o}}^{h}
$$

The planner's weights do not depend on the state of nature, thus they are constant, and individual consumption depends on the realization of consumption of the other network's member. I follow Fafchamps and Lund (2003) and Yang and Choi (2007) and define the budget constraint for each individual $i$ as,

$$
c_{s^{g}}^{i}=y_{s^{g}}^{i}+N \operatorname{Tr}_{j}^{i}
$$

where $N \operatorname{Tr}_{j}^{i}$ accounts for the net value of transfers received by individual $i$ and sent by individual $j$. Notice that $N \operatorname{Tr}_{j}^{i}$ enters individual i's budget constraint positive but individuals j's budget constraint negatively,

$$
c_{s^{g^{\prime}}}^{j}=y_{s^{g^{\prime}}}^{j}-N T r_{j}^{i}
$$

Individual income $y_{s^{g}}^{i}$ is decomposed into a permanent component $\left(\tilde{y}^{i}\right)$ and a transitory component $\left(y_{s^{g}}^{\prime i}\right)$, such that $y_{s^{g}}^{i}=\tilde{y}^{i}+y_{s^{g}}^{\prime i}$. Rearranging equation 5 , I get the equation for the net value of transfers received by the migrant:

$$
N \operatorname{Tr}_{h}^{m}=\frac{1}{2}\left\{\left(\tilde{y}_{s^{o}}^{h}-\tilde{y}_{s^{d}}^{m}\right)+\left(y_{s^{o}}^{\prime h}-y_{s^{d}}^{\prime m}\right)+\frac{1}{\theta}\left(\ln \omega_{m}-\ln \omega_{h}\right)\right\}
$$

Given that rain-fed agriculture is the main economic activity in the communities of origin, transitory income in this study is going to depend on observed agricultural shocks, rainfall shocks, which can be represented by $z_{s^{g}}^{i}$, such that

$$
\frac{\partial y_{s}^{\prime i}}{\partial z_{g}^{i}}<0
$$


Income response to rainfall shocks is allowed to be heterogeneous across locations,

$$
\frac{\partial y_{s}^{i}}{\partial z_{g}^{i}} \neq \frac{\partial y_{g^{\prime}}^{i}}{\partial z_{g}^{i}} \quad \forall i, g, g^{\prime}
$$

where $g \neq g^{\prime}$. This assumption allows for differences in productivity and in income diversification across locations, which makes sense given the distribution of migrants across different economic areas in Nicaragua and Costa Rica.

The model also assumes that the state of nature is heterogeneous across locations, $s^{g} \neq s^{g^{\prime}}$, a reasonable assumption in the case of Nicaragua,which is a small mountainous country with multiple micro-climates (Macours et al., 2012). Under this set of assumptions, I can derive a reduced form equation from Equation 8:

$$
\operatorname{NTr}_{h}^{m}\left(s^{o}, s^{d}\right)=\alpha+\beta_{o} z_{o}^{h}+\beta_{d} z_{d}^{m}+\gamma X_{m h}+\epsilon_{m}
$$

Where $\epsilon$ is a mean-zero error term. The function of Pareto weights and the permanent income component $\tilde{y}_{i}$ for the migrant and for the origin household can be captured by a vector of individual and household characteristics $X_{i j}{ }^{4}$ I allow $\beta_{o}$ to differ from $\beta_{d}$ as the impact of rainfall shocks on agricultural income may differ among locations. In Section 6 I test whether a decrease of one standard deviation in accumulated rainfall at origin and at location of destination has the same impact in magnitude (it should have the opposite sign) on the net value of transfer receipts, that is, I test whether $\beta_{o}+\beta_{d}=0$. I do not impose any assumption on the income response to shocks among households living in the same location $(g)$. Equation 8 suggests that when income shocks experienced by both agents are exactly the same, there would be no adjustment on the net amount of funds transferred. I test this result using migrants who experienced the same rainfall shock that the origin household did. If the impact of the rainfall shock is larger on one side than the other, I should observe an adjustment in the net value of transfers.

Equation 11 allows me to test whether net amount of transfers received by the migrant varies with shocks at origin and in destination. Negative income shocks affecting the origin household are expected to reduce the net value of transfers received by the migrant through two mechanisms. First, the amount of transfers received by the migrant (in-flow) is reduced as a consequence of a drop in income at origin (income effect). Second, the amount of remittances sent by the migrant (out-flow) to the origin household increases to compensate the income lost at origin (insurance mechanism). Therefore, to test whether the adjustment on the net value of transfers received is driven by an insurance behavior or whether it is driven by other factors, I derive two different equations from equation 11 accounting for the direction of the flow from migrant's perspective.

1. Transfers: transfers from the household head at origin to the migrant

$$
\operatorname{Tr}_{h}^{m}\left(s^{o}, s^{d}\right)=\alpha^{T r}+\beta_{o}^{T r} z_{s^{o}}^{h}+\beta_{d}^{T r} z_{s^{d}}^{m}+\gamma^{T r} X_{m h}+\epsilon_{m}^{T r}
$$

\footnotetext{
${ }^{4}$ In risk sharing literature the term average consumption is replaced by village or network shocks, Yang and Choi (2007) replace it by time effects. I don't have that aggregate component, instead I have permanent income from the origin household, which can be proxy by initial assets, location and household members, and the transitory component of income at origin, captured by the agricultural shock in origin.
} 
2. Remittances: transfers from the migrant to the household head at origin

$$
R_{h}^{m}\left(s^{o}, s^{d}\right)=\alpha^{R}+\beta_{o}^{R} z_{s^{o}}^{h}+\beta_{d}^{R} z_{s^{d}}^{m}+\gamma^{R} X_{m h}+\epsilon_{m}^{R}
$$

Equations 12-13 enable to test whether rainfall shocks are insured via inter-households transfers. I test two hypotheses:

Hypothesis 1 The origin household insures the migrant: $\beta_{d}^{T r}>0$

Hypothesis 2 The migrant insures the origin household: $\beta_{o}^{R}>0$

If income shortfalls from weather shocks are co-insured, $\beta_{d}^{T r}$ and $\beta_{o}^{R}$ should be positive. My identification strategy allows me to directly test both hypotheses; in addition I can estimate the impact of income shocks at the sender's location on the outflow of transfers,captured by $\beta_{d}^{R}$ and $\beta_{o}^{T}$. I expect the negative income shock at sender's location to decrease the amount of transfers sent (direct income effect). The size of $\beta_{d}^{T r}$ relative to $\beta_{o}^{R}$ provides some insight on whether the insurance contract is symmetric and both parties are insured in the same magnitude or is asymmetric and one party is better insured than the other. Nevertheless, the difference between coefficients might be driven also by differences on the vulnerability to weather shocks at either location.

I assume that migrant's and household head's decision regarding what they send does not depend on whether or not they receive transfers from the other party simultaneously, but on the income shocks at either location. For this insurance contract to work, households of origin and migrants need to have information on income shocks occurring at recipients' location. It might be reasonable to expect migrants to have reasonable good information on weather conditions at home due to social networks and return visits during holiday periods. But possibly it is harder for origin households to have good information about weather conditions at destination. As such there might be a trade-off between having less correlated shocks and information.

\section{Data}

I use two years of panel data from a household survey in rural Nicaragua. These data were collected to evaluate a Conditional Cash Transfer (CCT) program, Red de Protección Social, which was implemented starting in 2000 using a randomized phase-in process. ${ }^{5}$ I use data from a baseline census collected in May 2000 and a long-term follow-up survey conduced between November 2009 and November 2011 (henceforth, 2010 survey). ${ }^{6}$

The 2000 census includes questions about the characteristics and composition of the household, education and economic activities of household members, ownership of durable goods, land property, and information on agriculture activity. The 2010 survey was modeled following the 1998 Nicaragua

\footnotetext{
${ }^{5}$ The RPS intervention comprised two phases over six years. The pilot phase, started in 2000 and lasted three years. In 2003, the control group was phased in for three more years and the treatment communities stopped receiving the transfers. See (Flores and Maluccio, 2004; Maluccio, 2010) for results on the short-term effects of the program and (Barham et al., 2013b,a) for results on the long-term effects.

${ }^{6}$ This survey is part of a research project conducted by Tania Barham, Karen Macours, John Maluccio and Ferdinando Regalia
} 
Living Standards Measurement Study (LSMS) instrument. This round of data was collected making a significant effort to track individuals to reduce as much as possible attrition due to migration and household split-off. Households and individuals in the target group ${ }^{7}$ were tracked across Nicaragua and to Costa Rica. Multiple visits to the original communities reduced attrition in the sample due to seasonal migration. At the household level the attrition rate is below 8 percent. The target sample included 2,711 original households; during the follow-up the survey team interviewed 2,505 original households and 1,375 new households.

At the individual level, the sample used in this paper is restricted to respondents between the ages of 15 and 21 in 2010 (see Figure 1). My target sample contains 1,948 girls and 2,050 boys, among whom 1,675 girls and 1,834 boys were surveyed in $2010^{8}$. The attrition rate for girls is below 14 percent and for boys below 10 percent (see Tables A1-A3 in Appendix A). Leaving out household migration and 10 migrants from whom the original household was never found, that is 953 migrants. The household survey and tracking records provide reliable data on current location and allow me to conduct a robustness check by adding to the analysis migrants who were not found in 2010 (see Section 6.3).

These low attrition rates in such a mobile cohort (McKenzie, 2007), combined with the geographical spread of the sample and the rich information available at origin and destination, including GPS coordinates, make this database an excellent tool to analyze migration outcomes. Figure 2 shows the geographical distribution of young migrants in Nicaragua and Costa Rica. The map shows three flows of migration: migrants staying in their municipalities of origin (dashed regions) or in neighboring municipalities, migrants moving to the agricultural frontier (north-east) and to remote rural areas, and finally migrants moving to the Pacific Coast and around Managua and San José (Costa Rica). This third flow is formed mainly by urban migrants, while the first two are rural migrants and migrants moving to small urban areas. The distribution of rural migrants across space allows me to exploit the space-variation of rainfall shocks at destination.

\subsection{Migration from the sampled communities}

This paper analyzes the insurance role of transfers between migrants and their origin household regardless of the motivations behind the decision to migrate. Migrants in my sample were members of their origin household when the baseline survey was conducted in 2000. Ten years later, when the follow-up survey was implemented in 2010, they were part of a new household. I take the decision to migrate as given, and analyze the decisions to send transfers and remittances conditional on being a migrant. ${ }^{9}$ I assume that among those who have migrated, those who remit and/or receive transfers self-select differently ${ }^{10}$. While my identification strategy allows me to estimate the causal impact of

\footnotetext{
${ }^{7}$ The target group includes all households that have split-off, including those with both local and long-distance migrants, and that contain the main caregiver, an original panel household member under 21 (in 2010), or a child (under 21 in 2010) of an original household member

${ }^{8}$ This number does not include the deceased, 11 girls and 21 boys

${ }^{9}$ Tables C1- C2 in Appendix C shows that the decision to migrate in my sample is neither correlated with rainfall shocks in 2009 or with the dispersion of accumulated rainfall over the previous ten years at origin and at destination.

${ }^{10}$ In a comparative study on remittances in urban areas, Funkhouser (1995) found that besides similarities on observable characteristics between migrants, those remitting differ on unobservable characteristics from other migrants who do not remit.
} 
income shocks on remittances and transfers adjustments, the self-selection process of migrants restricts me from drawing any inference on the impact of migration on individual and household outcomes.

To identify the impact of income shocks on transfers I use standardized deviations of accumulated rainfall from the historical mean. The exogenous shock allows me to identify the causal effect of income shocks due to rainfall fluctuations on senders' behavior. Given the dispersion of migrants, I can look at different levels of correlation between shocks. To do so, I distinguish between local and non-local migrants using as a reference the rainfall data cell in which each household is contained. The rainfall data used in this paper comes in the form of grids of approximately $8 \mathrm{~km}$; I define local migrants as those who live in the same rainfall grid as their origin household. Non-local migrants live in a different rainfall grid so I can measure any difference in rainfall between the non-local migrant and the origin household. This group of migrants contains 430 individuals and will be the center of the analysis. The average (median) distance between the household of origin and the migrant destination is 900 meters (400 meters) for local migrants and around 40 kilometers (16 kilometers) for non-local migrants.

Theoretical and applied literature on migration suggest that rural and urban migration are motivated by different factors. To exploit this fact, I distinguish between migrants to urban and rural locations. I link the household database to DMSP-OLS Nighttime Lights ${ }^{11}$ to get accurate measures of urban areas. The images obtained identify lights from cities, towns, and other sites with persistent lighting. Using this data I define urban areas as those locations where the level of light intensity at night is above a threshold of 7 (of the 6-bit 0-63.0 range of the DSMP-OLS city lights produce). This process gives me an objective measure of urbanization in Costa Rica and Nicaragua. The level of light intensity is highly correlated with urban development, ${ }^{12}$ in the case of Nicaragua, I use a threshold of seven based on urban sites observed using Google Maps and data collected in the household survey. Migrants not located in these areas are considered rural migrants.

Because I am interested on the insurance mechanisms between migrants and non-migrating household members I restrict the sample to permanents migrants. Permanent migrants are defined, independently of the distance between the location of origin and of destination as those absent for more than nine months in the last 12 , or people that have left more recently but have no plans of returning in the short run. Apart from these migrants, my sample also has information on household migration, which occurs when all members migrate to the same location. In case of household splitoff, those moving with the designated caregiver of the CCT are considered migrant households and the others are considered individual migrants. A household member who migrates from a migrant household is reclassified as individual migrant and I include him or her in the corresponding category.

Surveyed migrants in my sample represent 40 percent of female young adults and 15.5 percent of male young adults (see Table A2 in Appendix A). These rates are in line with the fact that in Nicaraguan rural society young men are more likely to stay at their parents' house once they are married, while young women moved to their husbands' communities. Table 1 shows the distribution of migrants by destination. Around 80 percent of my sample moved to rural areas while around 20

\footnotetext{
${ }^{11}$ NOAA: The DMSP is a Department of Defense (DoD) program run by the U.S. Air Force Space and Missile Systems Center (SMC).

${ }^{12}$ Elvidge et al. (1997); Henderson et al. (2011) show that light density at night is a robust proxy of economic activity. These studies establish a strong within-country correlation between light density at night and GDP levels and growth rates.
} 
percent migrated to urban areas. Only 2 percent of migrants moved to Costa Rica. Given the small number of observations, I conduct the analysis on domestic migrants and migrants to Costa Rica together. Differences on baseline characteristics are driven by urban migrants who on average come from wealthier households and had more years of education in 2000 than the rest of the sample (see Table A4 in Appendix A). In general, the sample analyzed presents high levels of extreme poverty and low levels of education (household head had on average two years of education in 2000). The main economic activity at the communities of origin is rain-fed agriculture and only $16 \%$ of them had livestock at baseline.

Table 2 shows descriptive statistics for the cohort of interest in 2010. Those who stayed in their household of origin are less likely to be married in 2010 or to be the household head or his/her spouse $^{13}$ than those who migrated. These differences are especially large for local and rural nonlocal migrants. Almost all young adults in the sample are working at the date of the interview, and only 36 percent still at school. Even though one third of the sample is enrolled, 92 percent of them are working, which suggests that this cohort is old enough to be actively participating in economic transactions. Non-working migrants and those attending school are more likely to live in urban areas than in rural areas. The difference between these and the rest of the sample is driven by women who are married but are not working. In terms of education, local migrants have fewer years of education than non-local migrants, and the difference is driven again by urban migrants who have on average two more years of education. Around 60 percent of local migrants and rural non-local migrants have moved to get married (mainly women), while migrants to urban areas are more heterogeneous and move also to study, work or to find a better economic situation (see Table A5 in Appendix A).

\subsection{Remittances}

I have information on the amount of remittances sent and transfers received for 90 percent of my sample of migrants. ${ }^{14}$ The data on remittances and transfers on each migrant is reported by a member in the origin household (usually the household head) and not by the migrant. As a result, even when the migrant was found and interviewed later than the origin household, I have information on his or her transactions at the date when the origin household was surveyed. ${ }^{15}$ The data refer to transfers of funds done during the 12 months prior to the follow-up survey in 2010.

One third of the total sample of migrants received transfers and/or send remittances (34 percent and 33 percent respectively). Table 3 shows that at the extensive margin the rates of migrants sending and receiving remittances are not significantly different among destinations. At the intensive margin, urban migrants send more remittances (annual values) than rural migrants and local migrants. These results are in line with previous findings in the literature on the positive correlation between education and remittances. (Bollard et al., 2011) Rural non-local migrants received on average fewer transfers from their origin household than other migrants (local and urban migrants). Among urban migrants, both married and non-married received transfers from their original communities, although such transfers are more common among those who are still studying. Intuitively this makes sense: households are still investing in the education of their children, who on average have one more year

\footnotetext{
${ }^{13}$ In the rest of the text, the term "household head" refers to the household head and to her/his spouse

${ }^{14}$ For 3.6 percent of my sample of migrants I have data on transfer receipts but not on remittances sent.

${ }^{15} 96$ percent of the households of origin were interviewed before the start of the first crop season of 2010 .
} 
of education that those who did not receive transfers in 2010.

In my sample, urban migrants send total remittances for the value of 110 USD on average. While men are typically net payers (receive on average only 31 USD), women receive yearly almost the same that what they send (105 USD). Rural migrants are net contributors although the difference is very small. Finally, local migrants receive around 15 USD more than what they contribute. In relative terms with respect to the level of consumption in senders' households, urban migrants send remittances that account for 6 percent of expenditures on total consumption in destination, and they receive transfers for the value of 11.5 percent of total expenditures in origin. These percentages are smaller among rural migrants in local and non-local areas.

In general, those who remit tend to be the child of the head of the origin household, and they come from nuclear households with fewer young adult members. Among male migrants, I also observe some differences in land size holdings: those who send remittances and receive transfers come from households with smaller lands holdings. This holds at the intensive margin, which goes against the hypothesis that remittances are sent to improve migrants' inheritance outcomes. Summing up, those receiving transfers from their origin household are similar in baseline characteristics to those sending remittances, which supports the hypothesis of a cooperative contract in which both parties are actively involved. The only group in which I do not observe this behavior is the one formed by female migrants to urban areas. In this case, differences between those that send remittances and those that do not are almost zero, but those who receive transfers have more years of education than those who do not, and come from wealthier households.

\section{Weather and Agricultural Outcomes}

\subsection{Weather Shocks}

The historical rainfall data are taken from the "Gridded Analysis of Meteorological Variables in Nicaragua" (Uribe, 2011) and are available from 1979 to 2009. The data are available for a grid of $0.075^{\circ}$ (approximately every $8 \mathrm{~km}$ ) and are interpolated from existing weather stations (from the Nicaraguan Institute of Territorial Studies, INETER) and satellite data measured at a resolution of $0.1875^{\circ}$ (approximately every 20km) from NARR (the North American Regional Reanalysis) (Macours et al., 2012). For the sample of households of origin I use data from 53 nodes, and for the sample of young migrants the data comes from 127 nodes. Rainfall variables are constructed separately by node and households are assigned the rainfall data for the node geographically closest to their locations of origin and destination using GPS coordinates.

Drought events are important for agricultural output in Nicaragua. Insufficient rainfall over an extended period has particularly negative consequences for yields. In 2009, Nicaragua experienced a severe drought driven by El Niño; the Nicaraguan Institute of Territorial Studies (INETER, Spanish acronym) recorded deficit rainfall ranging between -14 and -50 percent over the rainy season. The direct consequences were felt in the production of basic grain, especially in the Dry Corridor where losses reached 50 percent of production (FAO, 2010). The rainfall deficit was especially large from the end of June to the beginning of October, delaying the start of the second season by 15 days on average. In Nicaragua there are two main growing seasons: from May to the end of August (Primera) 
and from the end of August to November (Postrera). Between both seasons there is a dry period, known as canicula which occurs between July 15th and August 15th and marks the change of the season. As a result, the data on agricultural outputs for the second agricultural season in 2009 may be incomplete as the data collection for the household follow-up survey starts at the beginning of November. Therefore, I focus on the first agriculture season of 2009, from May to August. The 2010 household survey does not include questions on economic shocks experienced at the household level, but data from the community questionnaire shows that $93 \%$ of the community leaders who completed the survey reported experiencing a drought in the previous 12 months.

The agronomy literature indicates the large losses of grain yields are caused by water deficits during the flowering season (Calvache et al., 1997), which depending of the crop variety occurs 48-60 days after sowing (corn) and 31-38 days after sowing (beans). This paper follows Macours et al. (2012) and focuses on water deficits during critical windows in the growth cycles. In particular I look at accumulated rain between June and July for the first growing season. The measure of rainfall shocks is defined as deviations of accumulated rain during the growing season from the historical mean ${ }^{16}$ divided by the standard deviation for each node (z-scores) at the grid level.

For households in the municipalities of origin the first growing season in 2009 was dryer than normal; Figure 3 shows the distribution of rainfall in standard deviation units for households of origin and for migrants who were found. Both figures show that very few households and only slightly more migrants experienced positive deviations on accumulated rain for this period. While almost 37 percent of the total households of origin experienced positive rainfall deviations, only 6 percent of the total sample actually experienced accumulated rainfall above 0.5 standard deviations from the historical mean. On the other hand, almost 17 percent of households of origin were exposed to rainfall deficits one standard deviation or more below the historical mean. Figure 4 shows the distribution of rainfall shocks across Nicaragua together with the distribution of non-local migrants. Thought Nicaragua is a small country, the map shows the large variation of rainfall shocks across regions. For ease of interpretation, the z-score rainfall variables are multiplied by minus one so they can be read as negative shocks.

\subsection{Agricultural outcomes and rainfall shocks}

The most common activity in this sample is farming: 89 percent of the household heads were involved in agricultural activities in 2000 and 90 percent of the land cultivated was used to grow temporal crops, basically beans and maize, while only 10 percent was allocated to permanent crops. ${ }^{17}$

Given that most original households in my sample depend principally on the cultivation of rain-fed crops, I expect weather fluctuations to drive changes in consumption or trigger risk-coping mechanisms. Table 4 shows the effect of rainfall fluctuations on food production and harvest outcomes among households at origin. ${ }^{18}$ The first column presents the estimated coefficients on rainfall z-scores

\footnotetext{
${ }^{16}$ Macours et al. (2012) provides evidence that drought shocks became more frequent after Hurricane Mitch in 1998. Post-1998 rainfall is lower during the first growing season and during the last months of the second growing season. I follow their specification and compute the historical mean using data from 1979 to 1998. The results are robust to computing the historical mean using data from 1979 to 2008.

${ }^{17}$ Statistics from The National Agricultural Census in 2001 show that in theses regions $79 \%$ of land used is allocated to grow basic grains ( $36 \%$ to maize and $30 \%$ to beans) and $15 \%$ is used to grow coffee

${ }^{18}$ Given the timing of the survey, I focus on the impact of weather shocks among households at the community of
} 
and the second column presents the estimated coefficients on a drought dummy taking value equal to one if rainfall is equal to or less than the historical grid mean minus one standard deviation. A one standard deviation decrease in accumulated rain reduces annual food production by 17 percent. This decline is driven by a 45 percent drop in the production of basic grains (maize and beans) and is confirmed by an increase in the amount of grains bought by 27 percent. The bottom panel of Table 4 presents the impact of weather shocks on the probability to sell, consume or lose the harvest at the end of the season. One standard deviation decrease in rainfall reduces the probability to sell grains by 10 percent and to consume them by 4 percent, while it increases the likelihood to lose the harvest by 3 percent. These results highlight the importance of the first growing season in food production and provide evidence of the direct effects of rainfall deficits on the main source of income for the region.

Are households exposed to adverse shocks able to smooth consumption? First two rows of Table 5 show the impact of rainfall fluctuations on the log of household income, first on agricultural income and second on household income regardless of the source. As expected from the results in Table 4, weather shocks have a large effect on income, one standard deviation decrease in rainfall decreases household agricultural income by 40 percent indicating that household income is quite sensitive to weather shocks. Total household income is reduced by 15 percent. Bottom panel of Table 5 presents the impact of rainfall fluctuations on the logarithm of total per capita consumption, food per capita consumption, and non-food per capita consumption. The lack of impact of weather shocks on consumption suggests that households are smoothing consumption in face of rainfall fluctuations. Taken together, these results show that households manage to protect against shocks even when their sources of income are jeopardized.

\section{Empirical Specification}

Understanding whether transfers act as an insurance mechanism requires estimating the causal effect of income shocks both on the migrant and the original household side. The previous section shows that rainfall deficits in my sample represent credible income shocks among households in rural areas. For urban migrants I assume rainfall fluctuations equal to zero, as their income should not be affected by changes in seasonal rain. ${ }^{19}$ As a robustness check I look at non-linear negative shocks using a dummy to capture whether the household and/or the migrant is exposed to a drought. I define drought as a binary variable taking value one if accumulated rainfall is equal to or less than the historical mean minus one standard deviation, and zero otherwise.

I estimate the following reduced-form equations for migrant $(m)$ derived in Section 2 (Equations 12 and 13):

1. Transfers: transfers from the origin household to the migrant

$$
\operatorname{Tr}_{h}^{m}\left(s^{o}, s^{d}\right)=\alpha^{T r}+\beta_{o}^{T r} z_{s^{o}}^{h}+\beta_{d}^{T r} z_{s^{d}}^{m}+\gamma^{T r} X_{m h}+\epsilon_{m}^{T r}
$$

origin. I restrict the sample to the original households of all the individuals in the age cohort of interest (15-21 years old). Including all households in the communities of origin do not change the results.

${ }^{19}$ Rainfall may affect food prices at the regional level, but it is very unlikely to affect market prices in Managua and San José. For the only migrant in non-urban areas in Costa Rica I assign him the shock of the nearest location in Nicaragua, the results do not change if I drop him from the sample 
2. Remittances: transfers from the migrant to the origin household

$$
R_{h}^{m}\left(s^{o}, s^{d}\right)=\alpha^{R}+\beta_{o}^{R} z_{s^{o}}^{h}+\beta_{d}^{R} z_{s^{d}}^{m}+\gamma^{R} X_{m h}+\epsilon_{m}^{R}
$$

Where $T_{h}^{m}$ accounts for the probability of receiving transfers from the origin household or the annual amount of transfers received, and $R_{h}^{m}$ accounts for the probability to remit or the annual amount of remittances sent by the migrant; $z_{s^{\circ}}^{h}$ is a measure of rainfall shocks at the origin household while $z_{s^{d}}^{m}$ is shocks at the migrant destination; $X_{m h}$ includes regional fixed effects at origin and at destination, ${ }^{20}$ location variables including altitude, vegetation index, distance to school and level of urbanization in 2000, and a set of baseline control variables at the household and at the individual level. $z_{s^{o}}^{h}$ and $z_{s^{d}}^{m}$ are measured as negative standardized deviations of accumulated rain during the first growing season (positive deviations account for periods with rainfall deficits compared to the historical mean). The coefficients of interest are $\beta_{o}$ and $\beta_{d}$ the impact of an decrease of one standard deviation in seasonal rainfall on the outcome variables. Finally, I can look at the net impact of shocks on the flow of transfers. The net value of transfers for each migrant is defined as,

$$
\begin{gathered}
N \operatorname{Tr}_{h}^{m}\left(s^{g}\right)=\operatorname{Tr}_{h}^{m}\left(s^{g}\right)-R_{h}^{m}\left(s^{g}\right) \\
N \operatorname{Tr}_{h}^{m}\left(s^{o}, s^{d}\right)=\alpha^{N T r}+\beta_{o}^{N T r} z_{s^{o}}^{h}+\beta_{d}^{N T r} z_{s^{d}}^{m}+\gamma^{N T r} X_{m h}+\epsilon_{m}^{N T r}
\end{gathered}
$$

I assume that the decision to send any transfer is taken jointly with the decision on the amount transferred, so I focus on the impact effect of rainfall shocks on the intensive margin. For each specification I look at five outcomes: probability to receive transfers from the origin household (column 1), probability to remit (column 2), amount of annual transfers (column 3), amount of annual remittances (column 4) and net amount of annual transfers received by the migrant (column 5 [3 -4]). I estimate Equations 14-16 by OLS, and standard errors are adjusted for clustering at the comarca level. ${ }^{21}$

\section{Results}

\subsection{Main Results}

Table 6 shows the estimated coefficients for non-local migrants. The last column shows the impact of shocks at origin and destination on the net value of transfers received by the migrant. Both coefficients $\left(\beta_{o}^{N T r}\right.$ and $\left.\beta_{d}^{N T r}\right)$ have the expected sign, meaning those exposed to negative income shocks are net recipients of funds. One standard deviation decrease in rainfall at origin reduces the net value of transfers received by the migrant by $20 \mathrm{USD}$, indicating that the net contribution of the migrant increases. Conversely, when migrants are exposed to negative shocks at destination their net benefits increase (P-value 0.16). In this case the adjustment is smaller, $8 \mathrm{USD}$, and it accounts for less than half of the change observed when shocks occur at origin.

In order to distinguish between the insurance and income component of the net effect, I decom-

\footnotetext{
${ }^{20}$ At origin regional I define regional fixed effects by area: Madriz, Matagalpa-West and EL Tuma -La Dalia. At destination I include regional fixed effects at the departmental level (17) in Nicaragua and at the country level for those who moved to Costa Rica.

${ }^{21}$ Census comarcas are administrative areas within municipalities based on the 1995 National Population and Housing Census that, on average, included 10 small communities for a total of approximately 250 households.
} 
pose the net value of transfers on the amount of transfers received and the amount of remittances sent by the migrant. One standard deviation decrease in rainfall at origin raises the amount of remittances sent by the migrant by 10 USD, indicating that migrants provide insurance to their origin household. On the other hand, rainfall shocks at destination do not have any impact on the amount of transfer receipts, suggesting that migrants are not insured by their origin household. Taken together, these results indicate that migrants are unilaterally insuring their origin household: the amount of remittances sent increases $\left(\beta_{o}^{R}>0\right)$ when the origin household is exposed to negative shocks, while shocks at destination do not increase the amount of transfers received.

On the income effect, Table 6 shows that both flows of funds (transfers and remittances) are adjusted by shocks happening on sender's location. The impact of shocks at destination on remittances is large, though not significant at the 10 percent level. A drop in household income due to rainfall shocks reduces the amount of transfers and remittances sent, suggesting that households and migrants in this environment are liquidity constrained, specially households of origin. This result is in line with the findings by Yang (2008b) in Philippines, who finds that exogenous increases in senders' resource have positive effects on the amount of funds transferred.

The last row of Table 6 contains the p-value for testing whether a rainfall shock at origin is the additive inverse of one at destination, that is $\beta_{o}+\beta_{d}=0$. First, I cannot reject the hypothesis that the coefficients are equal in magnitude (opposite-signed) in the equation of remittances. This result indicates that migrants adjust the amount of remittances sent by the same value regardless of whether the negative rainfall shock occur in their current location or in their location of origin. Second, on the equation of transfer receipts, the effects of rainfall shocks at origin and at destination are different in magnitude (P-value 0.14) indicating that households behave differently depending on who is exposed to negative income shocks. They adjust the amount of transfers sent in response to shocks happening in origin but not in migrant's destination. This difference drives the result on the equation of net transfers (P-value 0.087). Furthermore, Table 3 in Section 3.2 shows that the rate and the value of transfers and remittances between non-local migrants and their origin household are very similar, suggesting that the flow of funds is alike in both directions. One possible explanation of this pattern is the presence of asymmetric information concerning income shocks at either location. It is reasonable to expect that migrants may have reliable information on income realizations at home, due to social networks and return visits during holiday periods. It would be harder for households of origin to have perfect information on weather and income conditions at destination. In this case, asymmetric information on shocks would hamper the presence of co-insurance to a certain extent.

The lack of impact of rainfall shocks on the probability to remit and to receive transfers indicates that the adjustments on the annual amount of remittances and transfers is mainly coming from migrants who were already participating in economic transactions (around 34 percent of the sample of non-local migrants). The magnitude of the effect on this sample is about three times the size of the coefficients estimates in Table 6. ${ }^{22}$ Table 7 presents the estimates at the intensive margin, conditional on being participating in any economic transaction. One standard deviation decrease in rainfall at origin raises the amount of remittances sent by the migrant by 63 USD and decreases the amount of transfers received by the migrant by 26 USD. The impact of shocks at destination also are larger;

\footnotetext{
${ }^{22}$ As a robustness check Appendix B contains the tables for the main results under different specifications: non-linear rainfall shocks, results for impacts of rainfall shocks on the inverse hyperbolic sine transformations and the square root of transfers and remittances annual values. This final specification reduces the influence of outliers
} 
the income effect of one standard deviation decrease in rainfall reduces the amount of remittances sent by 61 USD. These estimates are more suggestive as they rely on the assumption that there is no selection on the extensive margin. ${ }^{23}$

As a robustness check, I restrict the sample to young adults between the ages of 18 and 21. This group is more likely to be economically independent, and it is reasonable to expect that if migrants are insuring the households of origin the results should be stronger. Tables 8 shows the results for this cohort of migrants. The impact effect of rainfall shocks on the amount of remittances and transfers it is slightly larger than in the benchmark cohort and the coefficients are more precisely estimated. These results also confirm that the income effect on transfers receipts $\left(\beta_{o}^{T r}\right)$ is not driven exclusively by the youngest group of migrants (15-17 years old). Indeed, one standard deviation decrease in rainfall in origin decreases the probability to receive transfers from the origin household by 11 percentages points, indicating that income effects affect not only the amount of transfers but also the participation on the economic arrangement. The results are consistent with the findings on the sample of those aged 15 to 21 .

How large is the unilateral insurance provided by the migrant? One standard deviation decrease of accumulated rainfall decreases household agricultural income by 43 USD and household total income by 95 USD at origin. Remittances from this pool of migrants compensate for 24 percent of the reduction in household agricultural income and 10 percent of the reduction in total household income. Although small, this level of insurance is relatively large when compared to the average annual value of remittances in the sample.

Overall, these results confirm that households in poor, rural areas exploit the spatial distribution of members of their extended network, in this case young migrants, to face agricultural shocks. In the rest of section 6 I focus on understanding the mechanisms behind the insurance contract and the trade-offs between correlated shocks and asymmetric information by looking at different pools of migrants.

\subsection{Interpretation and Mechanisms}

Equation 8 suggests than when income shocks at origin and at destination are exactly the same, there would be no adjustments on the net amount of funds transferred. Table 9 shows the results for all young local migrants, that is, migrants laying in the same rainfall grid than their origin household. Notice that the rate of migrants receiving transfers and sending remittances is very similar to the rate among non-local migrants: around 32 percent of local migrants and 34 percent of non-local migrants are involved in inter-household transfers. As expected, rainfall shocks do not have any impact on the amount of transfers received and remittances sent. As has been pointed out in the literature (Dercon and Krishnan, 2000; Duflo and Udry, 2004), high correlated income shocks are difficult to insure at the local level. Both sides may be suffering equally the deficits of rainfall, indicating that income

\footnotetext{
${ }^{23}$ The coefficients on the net value of transfers do not reflect the difference on the effect on transfers and remittances as in this case it doesn't include any value equal to zero. Therefore, in the case where a migrant receives transfers from home but doesn't sent remittances, he or she is included in the regression on transfers and on net value of transfer but he or she won't be included in the regression on remittances.
} 
response to rainfall shocks may be homogeneous among households living in the same location:

$$
\frac{\partial y_{s^{g}}^{i}}{\partial z_{g}^{i}}=\frac{\partial y_{s^{g}}^{j}}{\partial z_{g}^{j}} \quad \forall i, j, g
$$

To analyze how correlation between income shocks affects the insurance role of remittances and transfers, I look at different levels of correlations between shocks, first by destination and second by economic activity.

\section{Spatial Distribution of Migrants: urban versus rural migrants}

As mentioned in Section 3 urban and rural migrants to no-local areas differ from each other. The pool of migrants moving to urban areas come from wealthier households and have more years of education than other migrants. Their income is less vulnerable to rainfall fluctuations and therefore less correlated to income shocks occurring at their location of origin. On the other hand, around 60 percent of non-local migrants moved to rural areas where they work mainly in agricultural activities, making this group highly vulnerable to rainfall shocks. To account for these differences and for different levels of correlation between income shocks at origin and at destination, I split the sample into migrants moving to urban areas and migrants moving to rural areas.

Table 10 shows the estimated coefficients by non-local migrants' current location. The top panel shows the results for urban migrants and gives strong evidence on the unilateral insurance mechanism by which origin household are insured by young migrants. As mentioned before, urban migrants are not exposed to rainfall shocks at destination. ${ }^{24}$ One standard deviation decrease in rainfall at origin raises the amount in remittances sent by the migrant by about 16 USD, twice the effect found in Table 6. The income effect is also strong and large; migrants' transfer receipts decrease by 18 USD in face of negative shocks at origin and the net amount of transfers falls to 35 USD. Remittances from young urban migrants compensate for 38 percent (17 percent) of the reduction in household agricultural (total) income due to a one standard deviation decrease in accumulated rainfall at origin. The bottom panel presents the results for non-local rural migrants. But coefficients are neither significant for remittances nor for transfers. In particular, there is no evidence of any insurance mechanism functioning between the average rural migrant and his or her origin household. For non-local rural migrants the estimated coefficient on the net value of transfers received by rural migrants shows that they receive fewer transfers when their origin household is exposed to negative rainfall shocks.

Differences between the two types of migrants could be explained by migrants' characteristics, for example urban migrants may be less liquidity constrained than their rural counterparts (see Table 2). Still, the lack of insurance provided by the average rural migrant could also be explained by the fact that they and their origin household might be exposed to highly correlated weather shocks. If that is the case, it is reasonable to expect that rural migrants will not insure their household of origin in the face of weather shocks and vice-versa. Using the rainfall grid to distinguish local and non-local migrants has the inconvenience that rural non-local migrants may still be living very close to their

\footnotetext{
${ }^{24}$ Table B1 in Appendix B show the results including rainfall shocks at destination. The estimated coefficients on shocks at origin are not affected while none of the coefficients on rainfall shocks at destination are significantly different from zero
} 
communities of origin and therefore remain exposed to highly correlated shocks.

Spatial Distribution of Migrants: rural migrants with more or less covariate shocks

To analyze whether high levels of correlation between rainfall fluctuations in origin and destination are driving the results for rural migrants, I compute the absolute value of the difference between rainfall deviations and, based on the result, construct different samples of migrants. This strategy allows me to reduce spatial correlation without imposing any assumption on the income effect of rainfall fluctuations in each location $\left(z_{s^{o}}, z_{s^{d}}\right)$. The absolute value of the difference does not capture whom is exposed to the larger shock. Given that I do not have self-reported data on the intensity of shocks, I do not know whose income is more vulnerable to rainfall deviations, and therefore I cannot establish whether the origin household or the migrant are better or worse off.

Figures 5 and 6 show the results for running Equations 14 and 15 on different samples of migrants. The vertical axis shows the coefficients capturing the insurance role of transfers and remittances, that is $\beta_{d}^{T r}$ and $\beta_{o}^{R}$ respectively. The values in the horizontal axis represent the minimum difference in absolute values between rainfall deviations in origin and destination in each sample $\left(\delta_{a b s}=\left|z_{s^{o}}-z_{s^{d}}\right|\right)$.

Both graphs show a positive relation between the absolute difference between shocks and the level of insurance. Consistent with previous findings, this tendency is especially significant when shocks occur at origin. Rural migrants living in areas exposed to shocks at least 0.45 points bigger or smaller than their household of origin adjust their remittances by almost 10 USD, which accounts for two thirds of the impact observed among urban migrants. Figure 6 shows that when the correlation between rainfall shocks shrinks, young rural migrants provide insurance to their origin household. This result is important as it indicates that even migrants with low levels of education (around five years of schooling in 2010), working in agricultural activities (85 percent of them works only in agriculture), and who are married and economically independent (77 percent are married and 62 percent are household heads in 2010) are still providing insurance to their origin household. Are they also receiving insurance?

Figure 5 shows that the level of insurance increases as shocks between locations are less correlated but it decreases again when differences between shocks increase. The peak of insurance gets as far as 6 USD when the absolute difference between shocks is between 0.2 and 0.3 points. Although small, this result suggests that households of origin may provide some insurance to migrants exposed to negative rainfall shocks, so long as the migrants are not living too far. The figure also shows that as distance between locations increases, the implementation of such an insurance mechanism aimed to protect the migrants weakens. The reduction on the insurance effect as the difference between shocks increases is consistent with the presence of some information or enforcement costs that are likely to increase with distance.

All together, these results point to the presence of co-insurance informal arrangements, in which households receive higher levels of protection. The estimated coefficients on the net value of transfers show that taking into account the income effect does not change this result: households of origin are net beneficiaries when they are exposed to negative shocks (see Figures 7-8 in Appendix B). 
Households of origin and migrants might also be exposed to less covariate shocks when they are active in different types of economic activities. In this section I investigate the implications of income correlation between the household of origin and the migrant by looking at migrants' economic activity. I look at whether migrants who are involved only in agricultural activities provide the same level of insurance as migrants working only in non-agricultural activities or combining non-agricultural and agricultural activities. (25 percent of migrants working on non-agricultural activities are also working on the agricultural sector.) On one hand, those working only in agricultural activities are not only more likely to be vulnerable to rainfall shocks, but also their income is presumably more correlated to their origin household's income. On the other hand, Macours et al. (2012) show that in rural Nicaragua diversifying economic activities makes households less vulnerable to weather shocks.

Table 11 shows the results for the pool of migrants divided between those working only on agricultural activities (top panel) and those combining agriculture and non-agriculture or working only in non-agricultural activities (bottom panel). The results are in line with the findings on the spatial distribution of migrants. Those working only in agricultural activities do not provide, neither receive, any insurance through the flow of transfers. As rural migrants, migrants involved only on agricultural activities receive less transfers when households are exposed to shocks at origin.

On the other hand, I find that those migrants working in non-agricultural activities provide insurance to their household of origin. A one standard deviation decrease in accumulated rainfall raises the annual amount of remittances by 23 USD. Notice, that around 34 percent of non-local migrants working on non-agricultural activities are rural migrants, thus this result is not driven only by urban migration. On the other hand, the results at the extensive margin suggest that migrants working in both sectors are insured by their origin household origin. One standard deviation decrease in rainfall at destination raises the probability to receive transfers from the origin household by 18 percentage points. This result may reflect a strategic behavior on the part of the household of origin: they may be interested in contracts with migrants with diversified income.

To analyze whether this strategic behavior explains the results, I restrict the sample to migrants for whom the head of household of origin works only on the agricultural sector. Table 12 shows the results for this sub-sample of migrants. A one standard deviation decrease in rainfall at origin raises the amount of remittances sent by the migrant by 19 USD, which is 50 percent more than the adjustment on remittances observed on the whole sample (the differences between coefficients is significantly different from zero, see Table B2 in Appendix B ${ }^{25}$ ). Contrary to the results obtained in the whole sample, in this sub-sample of migrants, the effects of rainfall shocks at origin and at destination on the amount of remittances differ in size, suggesting that a negative rainfall shock at origin leads to a larger adjustment by the migrant than a shock at destination. This result is in line with the hypothesis that households rely on remittances sent from migrants whose income is less vulnerable to rainfall shocks. Finally, the income effect of a shock in origin is similar between samples, indicating that it may be independent of the insurance arrangement.

Table 13 presents the results, by economic activity, for the pool of migrants for whom head

\footnotetext{
${ }^{25}$ To capture heterogeneity effects between different samples of migrants or households in origin, I introduce in Equations 14-16 a dummy variable capturing characteristic $K$ and an interaction term between characteristic $K$ and each rainfall shock:

$$
T_{h}^{m}\left(s^{o}, s^{d}\right)=\alpha^{T}+\beta_{o}^{T} z_{s^{o}}^{h}+\delta_{o}^{T}\left(z_{s^{o}}^{h} * K\right)+\beta_{d}^{T} z_{s^{d}}^{m}+\delta_{d}^{T}\left(z_{s^{d}}^{m} * K\right)+\lambda K+\gamma^{T} X_{m h}+\epsilon_{m}^{T}
$$
}


of household at origin works only in the agricultural sector. Migrants working only in agricultural activities provide insurance to households who derive income only from the agricultural sector, but there is no evidence of insurance in the opposite direction.

The bottom panel shows the results for those migrants working in the non-agricultural sector. The effect of rainfall shocks at origin on the magnitude of transfers received and remittances sent is especially large (households adjust their transfers by 26 USD and migrants by 44 USD), while the effect of rainfall shocks at destination is not significantly different from zero. This result is in line with the idea that this group of migrants is less vulnerable to rainfall shocks because they diversify their labor portfolio across sectors. Finally, migrants working in both sectors are co-insured by their households in origin at the extensive margin. The adjustment on the value of transfers is very small and not significant, which suggests that the adjustment occurs at the extensive margin.

The results above point out that risk-sharing arrangements between migrants and their households of origin are heterogeneous by destination and economic activity. As expected, those who are exposed to less correlated shocks are more likely to participate in an insurance arrangement. The effect of rainfall shocks in the net value of transfers received by non-local migrants differ in magnitude depending on the location of the shock, suggesting that the economic contract is not symmetric. On average, the adjustment on the transfer of funds is larger when negative shocks occur at the location of origin.

In the following section I analyze whether this economic arrangement holds for a group of migrants for whom the information between households and migrants is likely to be imperfect. In particular I now add to the sample those migrants in the cohort of interest (15-21 years old) who were traced but not found during 2010 follow-up survey, i.e. the attritors. Adding this sample, I expect households of origin to be less likely to react to shocks at destination, as they may have less information on their migrant's current location and therefore economic situation.

\subsection{Attrition}

During the 2010 follow-up survey the research team made a great effort on minimizing attrition at the households and at the individual level. As a result, attrition rates for the cohort of interest are below 10 percent for men and 14 percent for women over a period of 10 years. Among them 20 percent moved with their entire households, 27 percent were untraceable (the survey team could not obtain any information regarding their destination), less than 1 percent refused to be surveyed. The rest were individual migrants ( 53 percent) for whom a proxy destination was obtained, even if the migrants were subsequently not found at that destination. This latter group can be added to the previous analysis using information reported by other household members who were found during the tracking protocol. As before, the data on transfers and remittances come from the questionnaire filled by the household of origin, and the sample is restricted to those for whom household of origin was interviewed before the harvest of the first season in 2010. This group is not included in the analysis from the beginning because, in order to look at shocks at destination, I have to rely on proxy information on migrant's location. Adding the sample of attritors increase the sample size, but it also introduce noise in the 
regression, as the shocks at destination are less precise. ${ }^{26}$

To construct migrants' shocks, I use data reported by the household and information collected during the tracking protocol by the enumerator team. Of the 241 individual migrants not found but traceable, 165 were assigned to a micro-region, ${ }^{27}$ for $32 \mathrm{I}$ only have data on the municipality of destination and 44 were reporting to be living in another country (64 percent of them in Costa Rica). Depending on the level of information available, I follow different strategies to merge the sample of non-found migrants to the rainfall data: at the micro-region level I compute the geographic centroid of each micro-region and I assign them to the nearest rainfall grid. For those from whom I only have the name of the municipality, I assign them the shock of the most common micro-region destination in my sample of migrants for each municipality, and in case they were the only ones moving to a municipality I compute rainfall shocks at the municipality level by taking the average of all the rain grids inside each municipality. I restrict the analysis to migrants in Nicaragua or Costa Rica. ${ }^{28}$

Table 14 shows the main results after adding the sample of attritors from whom I have information on the household of origin and on the location at destination. The rate of migrants not found in this cohort sending remittances to their household of origin is almost the same as the rate among those found (31 percent versus 33 percent respectively), but the rate of those receiving transfers is much smaller (17 percent versus 34 percent). The top panel presents the results for migrants found and not found inside Nicaragua. A one standard deviation fall in accumulated rainfall decreases transfer receipts by 3.7 USD and remittances sent by 6.6 USD (only the coefficient estimated on transfer receipts is significantly different from zero). This result indicates that there is a decrease in the size of the insurance effect on remittances and especially on the income effect on transfers compared to those found. The coefficient on the impact of shocks at destination on transfer receipts is almost zero, supporting the hypothesis that the lack of information on the migrant's situation may explain the lack of insurance provided by the household of origin.

In the bottom panel I extend the sample to include migrants to Costa Rica; the coefficients further decrease as I introduce migrants located farther away. These results should be taken cautiously as they might be driven by measurement errors on the weather shocks.

\subsection{Income Effect}

In addition to the insurance effect, the results show a strong negative impact of negative rainfall shocks at origin on transfer receipts. It is hard to test whether this income effect responds to an altruistic motive, is part of the insurance contract, or is driven by other purposes. For example, in a exchange model, migrants would be providing loans that would be repaid when the household experiences an income surplus. In that case, the income effect $\left(\beta_{o}^{T r}\right)$ and the insurance effect $\left(\beta_{o}^{R}\right)$ should be observed together. The results on rural migrants (top panel of Table 10) and on migrants working in agricultural activities (top panel of Table 11) already suggest that the income effect is

\footnotetext{
${ }^{26}$ Also, the fact that these migrants were not found during the tracking protocol could be in part because the enumerator team did not get the correct information on their location to start with.

${ }^{27} \mathrm{~A}$ micro-region is an administrative area smaller than a municipality and bigger than a comarca, defined by the National Institute of Information and Development (INIDE) and it represents geographic areas which are similar in terms of socio-economic outcomes and micro-climates.

${ }^{28} \mathrm{I}$ have information on remittances and transfers for only 15 international migrants (not counting those moving to Costa Rica).
} 
present even when migrants do not provide insurance. To better understand the mechanisms behind the income effect and whether it is correlated with the insurance effect, I analyze how the main results are affected by looking at different pools of migrants based on observables characteristics.

Around 70 percent of female and 30 percent of male migrants were married at the time of the follow-up survey. Almost 21 percent of married migrants in my sample (particularly women migrants) are living in the household of their partner's parents or other relatives of their partner. Presumably they have less access to household income and therefore are less likely to send remittances to their household of origin. Table 15 presents the results of running equations 14-16 including interaction effects for non-married migrants and migrants who are not the head of household or his/her spouse. The top panel of Table 15 shows that the income effect of one standard deviation decrease in accumulated rainfall at origin prevails among married and non-married migrants (the difference is not significant) while non-married migrants are the ones insuring their origin household. The interaction term between not being married in 2010 and the shock at origin is large and significant at the extensive margin (12 percentage points), while the coefficient on the amount of remittances sent is large but not significantly different from zero.

These findings suggest that the income effect due to rainfall fluctuations in origin cannot be explained as a repayment mechanism of remittances received. The fact that the income effect is observed among married migrants and migrants who have became the head of household (see bottom panel of Table 15) indicates that the income effect is not explained by households investing in migrants who are likely to return to the communities of origin. Table 16 shows that the income effect of shocks at origin is also independent to whether the migrant is enrolled or not.

These findings indicate that exogenous drops in income at origin decrease transfer receipts regardless of whether the migrant is insuring his or her origin household or not. By looking only at young adult migrants I cannot say whether the insurance contract is permanent, and a response to a long-term strategy, or is just temporary. It is reasonable to believe that the observed flow of transfers from the household of origin to the migrant may be driven by a life cycle component. During good seasons, households help young adults leave the nest and settle elsewhere; during lean seasons, they reduce their transfers. In this case, the insurance provided by the migrant could be also temporary and be observed among young migrants during the period of life transition. To test this hypothesis, I analyze the flow of transfers and remittances among migrants in the next age cohort (22-30 years old). If the life cycle hypothesis is true, I expect transfers and remittances to drop as migrants get older.

\subsection{Older cohort}

Using data from the questionnaire filled out during the follow-up survey by the origin household, I can look at the impact of weather shocks on remittances sent and transfers received by migrants who in 2010 were between 22 and 30 years old. I restrict the sample to migrants under 30 as I only have information on migrants who were household members in 2000. The attrition rate in this group is about 49 percent, and 31 percent of the migrants who were found were living in a non-local area. I replicate the steps followed in Section 6.3. Because this cohort was not part of the tracking sample I use data on their location reported by the origin household. Among those not found, I have proxy 
information about their destination for 64 percents (47 percent at the micro-region level, 7 percent at the municipality level and the remaining 10 percent are living in another country).

Table 17 presents the results for this sample of migrants. The top panel is restricted to migrants inside Nicaragua. A one standard deviation decrease in rainfall in origin raises the amount of remittances sent by the migrant by 6 USD and it has no effect on the level of transfers received. Almost 30 percent of non-local migrants in this cohort are receiving transfers from the household of origin, but the decision to send transfers or the amount sent is not affected by income shocks, neither in origin or in destination. Compared to the results for the youngest cohort (Table 6), the income effect of rainfall shocks at origin on the value of remittances is very similar in magnitude.

Together, these results provide further evidence of the lack of relationship between the insurance and the income effects. The income effect seems to respond to a life cycle model in which the household of origin transfers funds to young migrants during ages of life transition. On the other side, older migrants still sending remittances and provide similar level of insurance than migrants in younger cohorts. These estimates should be viewed cautiously because of the use of proxy information, there is more measurement error in the variable measuring shocks at destination. This measurement error does not affect the shocks at origin, so the coefficients on the income effect of shocks at origin are comparable with those of the younger cohort.

\section{Other risk-coping mechanisms}

Are households that are not receiving remittances smoothing consumption? Table 5 shows that households are able to smooth consumption even if their income has shrunk, splitting the sample by those receiving or not remittances do not change the results. Table 19 shows that including income from non-agricultural activities does not cancel the lost income, but it might reduce the impact of rainfall deficits. While households without migrants seem to rely on other risk-coping mechanisms, these may potentially come with important long-term costs.

Previous studies on risk management in rural areas have looked at changes on asset levels to buffer against income shocks, among them, livestock has been considered a key asset that households may use to cope with risk (Rosenzweig and Wolpin, 1993; Fafchamps et al., 1998). Table 18 displays the impact of weather shocks on the level of assets and on livestock by households who received remittances and those who do not receive remittances from migrants living in other communities. The assets index is constructed using principal-component factor analysis on a list of assets. ${ }^{29}$ Table 18 reveals that households in this framework use durable assets and livestock as buffer stock in face of rainfall deficits. These results are mainly driven by households not receiving remittances from outside the community. Even if the estimated coefficients are not large, they highlight that households receiving remittances might be less likely to deplete their asset stock when shocks hit.

Table 19 shows the impact of weather shocks on the share of households members involved in different economic activities. The size of the coefficient suggests that households do not rely on seasonal migration or labor diversification ex-ante to be fully insured. The estimated coefficient points

\footnotetext{
${ }^{29}$ The list of assets includes: pumping machine,draft animals, corn grinder machine, television, radio, small tools, sewing machine and oven.
} 
out that in the face of weather shocks, households substitute sales of food product and services ${ }^{30}$ with sales of other manufacturing products. This risk-coping behavior again seems larger among those not receiving remittances. These results should be interpreted with caution as the two types of households are not really comparable. As I show in Section 3 migrants come from households with different observable characteristics. These characteristics, which could be correlated with the decision to migrate, with the choice of destination, and with the implementation of an insurance mechanism, also determine the degree of vulnerability of each household.

\section{Conclusion}

Domestic and regional migration represents almost 75 percent of an estimated 1 billion migrants worldwide (UNDP, 2009). In poor rural areas with no access to credit or insurance markets, remittances from these migrants represent an important source of income and a plausible mechanism to cope with income shocks. The potential impact of internal migrants is intensified by the fact that internal remittances, though smaller in terms of individual transfers, tend to be redistributed back to the poorest sectors of society in greater and more regular amounts than international remittances (Deshingkar and Grimm, 2004; Hickey et al., 2013). Using household survey data on poor communities in rural Nicaragua this paper has examined how inter-household transfers between migrants and their household of origin are adjusted in face of income shocks. Taking advantage of the data on migrant's destination, I look at the impact of income shocks at origin as well as at destination by different type of migrants (rural versus urban, economic activity) and show that regional migration serves as insurance mechanism against agricultural shocks.

For households with non-local migrants, a one standard deviation decrease in accumulated rainfall at origin increases remittance receipts by 10 USD. This increases to 19 USD for migrants whose household of origin works only on the agricultural sector and are thus especially vulnerable to rainfall shocks. The adjustment on the amount of remittances is especially large among migrants who might be exposed to different economic shocks than their origin household. For instance, urban migrants and migrants diversifying economic activities provide a larger level of insurance. Among rural migrants, the transfer of fund increases as the correlation between rainfall fluctuations at origin and destination decreases. There is evidence at the extensive margin of the presence of a co-insurance mechanism in which both parties are insured. This co-insurance agreement is observed among migrants combining agricultural and non-agricultural activities, or among rural migrants when the correlation between shocks is reduced.

Beside the insurance mechanism, households also adjust their flows of transfers when they are the ones experiencing rainfall shocks. The sign of the causal effect indicates an income effect -that is, the outflow of transfers decreases with negative rainfall shocks. This income effect on households' transfers occur regardless of migrants' characteristics, which suggests that is not correlated with the insurance mechanism. These findings indicate that the transfer of funds between migrants and their origin household may not be permanent indicating the presence of a life-cycle component. Estimates on a sample of older migrants (22-30 years old) confirm this hypothesis.

While the paper shows significant evidence of the insurance and income effects, the magnitude

\footnotetext{
${ }^{30}$ Self-employed services provided at home are correlated with food production at home
} 
of the effects are modest. For the average migrant, the economic value of the exchange is not large and households not receiving remittances in my sample are able to smooth consumption using other risk-coping strategies. On average, remittances received from non-local migrants compensate for 10 percent of the reduction in household income due to a one standard deviation decrease of accumulated rainfall. The level of insurance increases among households with migrants involved in non-agricultural activities, in this case remittances compensate for 24 percent of the reduction in household income. Smoothing is considerable when taking into account that transfers and remittances are only small percentage of consumption per capita (see Tables 3). A question remains concerning those households who actively keep networks across space are better off than other households, and even, how are these links affecting migrants' outcomes. In Section 7, I analyze other mechanisms that households may use to face income shocks and smooth consumption. The results indicate that adverse rainfall shocks lead to a reduction in assets and livestock and to some labor diversification especially among households not receiving remittances. Rainfall shocks could lead to poverty traps in the long run through asset depletion, I find some evidence that this may be less important for households who rely on migrants for insurance.

There has been a significant interest in policies targeting international and seasonal migration, while policies targeting domestic and regional migration have received less attention. Transfers and remittances between origin households and their regional migrants help insure both sides against negative income shocks. The results on rural migrants also suggest that this insurance mechanism is activated when shocks between locations are not highly correlated. On the other hand, this mechanism can be limited due to information asymmetries on rainfall and income shocks. In this light, recent evidence on the impact of mobile technologies suggest that could be important to facilitate these information flows and to reduce other transaction costs (Blumenstock and Fafchamps, 2013; Jack and Suri, 2014). This paper provides further evidence on the importance of analyzing the returns of domestic and regional migration in developing countries. Overall, the welfare implications of this insurance mechanism at the household and at the migrant level are unknown and they constitute an important area for further research. 


\section{References}

Altonji, J. G., F. Hayashi, and L. J. Kotlikoff (1992). Is the extended family altruistically linked? direct tests using micro data. The American Economic Review 82(5), pp. 1177-1198.

Ashraf, N., D. Aycinena, D. Yang, et al. (2014). Savings in transnational households: A field experiment among migrants from el salvador. Review of Economics and Statistics. Forthcoming.

Aycinena, D., C. Martinez, and D. Yang (2010). The impact of remittance fees on remittance flows: Evidence from a field experiment among salvadoran migrants. Mimeo.

Barham, T., K. Macours, and J. A. Maluccio (2013a). Boys' cognitive skill formation and physical growth: Long-term experimental evidence on critical ages for early childhood interventions. The American Economic Review 103(3), pp. 467-471.

Barham, T., K. Macours, and J. A. Maluccio (2013b). More schooling and more learning?: Effects of a three-year conditional cash transfer program in nicaragua after 10 years. IDB Working Paper Series No.IDB-WP-432.

Batista, C. and G. Narciso (2013). Migrant remittances and information flows: Evidence from a field experiment. IZA Discussion Paper No. 7839.

Blumenstock, J. and M. Fafchamps (2013). Motives for mobile phone-based giving: Evidence in the aftermath of natural disasters. Unpublished.

Bollard, A., D. McKenzie, M. Morten, and H. Rapoport (2011, May). Remittances and the brain drain revisited: The microdata show that more educated migrants remit more. World Bank Economic Review 25(1), pp. 132-156.

Bryan, G., S. Chowdhury, and A. M. Mobarak (2014). Under-investment in a profitable technology: The case of seasonal migration in bangladesh. Econometrica. Forthcoming.

Calvache, M., K. Reichardt, O. Bacchi, and D. Dourado-Neto (1997). Deficit irrigation at different growth stages of the common bean (phaseolus vulgaris 1., cv. imbabello). Scientia Agricola $\underline{54}$ (SPE), pp. 1-16.

Clarke, G. and S. Wallsten (2003). Do remittances act like insurance? evidence from a natural disaster in jamaica. Development Research Group, The World Bank. Mimeo.

Cox, D., Z. Eser, and E. Jimenez (1998). Motives for private transfers over the life cycle: An analytical framework and evidence for peru. Journal of Development Economics 55(1), pp. 57-80.

De la Briere, B., E. Sadoulet, A. De Janvry, and S. Lambert (2002). The roles of destination, gender, and household composition in explaining remittances: an analysis for the dominican sierra. Journal of Development Economics $\underline{68}(2)$, pp. 309-328.

De Weerdt, J. and S. Dercon (2006). Risk-sharing networks and insurance against illness. Journal of $\underline{\text { Development Economics }}$ 81(2), pp. 337-356.

De Weerdt, J. and K. Hirvonen (2013). Risk sharing and internal migration. World Bank Policy Research Working Paper (6429). 
Dercon, S. and P. Krishnan (2000). Vulnerability, seasonality and poverty in ethiopia. The Journal of Development Studies 36(6), pp. 25-53.

Deshingkar, P. and S. Grimm (2004). Voluntary internal migration: an update. Paper commissioned by the Urban and Rural Change Team and the Migration Team, Policy Division, DFID. ODI. September 2004.

Duflo, E. and C. Udry (2004, May). Intrahousehold resource allocation in cote d'ivoire: Social norms, separate accounts and consumption choices. NBER Working Papers (10498).

Elvidge, C. D., K. E. Baugh, E. A. Kihn, H. W. Kroehl, and E. R. Davis (1997). Mapping city lights with nighttime data from the dmsp operational linescan system. Photogrammetric Engineering and $\underline{\text { Remote Sensing }} \underline{63}(6)$, pp. 727-734.

Fafchamps, M. and S. Lund (2003). Risk-sharing networks in rural philippines. Journal of development Economics $71(2)$, pp. 261-287.

Fafchamps, M., C. Udry, and K. Czukas (1998). Drought and saving in west africa: are livestock a buffer stock? Journal of Development economics 55(2), pp. 273-305.

FAO (2010). Evaluación rápida de seguridad alimentaria y nutricional en 23 municipios del corredor seco de nicaragua. Technical report.

Flores, R. and J. Maluccio (2004). Impact evaluation of a conditional cash transfer program: The nicaraguan red de proteccion social. Discussion Paper N.184. International Food Policy Research Institute.

Funkhouser, E. (1995). Remittances from international migration: A comparison of el salvador and nicaragua. The Review of Economics and Statistics 77(1), pp. 137-146.

Gubert, F. (2002). Do migrants insure those who stay behind? evidence from the kayes area (western mali). Oxford Development Studies 30(3), pp. 267-287.

Henderson, V., A. Storeygard, and D. N. Weil (2011). A bright idea for measuring economic growth. The American Economic Review 101(3), pp. 194-199.

Hickey, M., P. Narendra, and K. Rainwater (2013). A review of internal and regional migration policy in southeast asia. Migrating Out of Poverty Working Paper 8.

Jack, W. and T. Suri (2014). Risk sharing and transactions costs: Evidence from kenya's mobile money revolution. The American Economic Review 104(1), pp. 183-223.

Lucas, R. E. and O. Stark (1985). Motivations to remit: Evidence from botswana. The Journal of Political Economy $93(5)$, pp. 901.

Mace, B. J. (1991). Full insurance in the presence of aggregate uncertainty. Journal of Political Economy $\underline{99}(5)$, pp. 928-956.

Macours, K., P. Premand, and R. Vakis (2012). Transfers, diversification and household risk strategies : experimental evidence with lessons for climate change adaptation. World Bank Policy Research Working Paper (6053). 
Maluccio, J. A. (2010). The impact of conditional cash transfers on consumption and investment in nicaragua. The Journal of Development Studies 46(1), pp. 14-38.

McKenzie, D. (2007). A profile of the world's young developing country migrants. World Bank Policy Research Working Paper (4021).

McKenzie, D. (2012, Mar). Learning about migration through experiments. CReAM Discussion Paper Series (1207).

Morduch, J. (1995). Income smoothing and consumption smoothing. The Journal of Economic Perspectives $\underline{9}(3)$, pp. 103-114.

Rapoport, H. and F. Docquier (2006). The economics of migrants' remittances. Handbook of the economics of giving, altruism and reciprocity 2, pp. 1135-1198.

Rosenzweig, M. R. and K. I. Wolpin (1993). Credit market constraints, consumption smoothing, and the accumulation of durable production assets in low-income countries: Investments in bullocks in india. Journal of political economy 101(2), pp. 223-244.

Townsend, R. M. (1994). Risk and insurance in village india. Econometrica 62 (3), pp. 539-591.

Udry, C. (1994). Risk and insurance in a rural credit market: An empirical investigation in northern nigeria. The Review of Economic Studies 61(3), pp. 495-526.

UNDP (2009). Human Development Report: Overcoming Barriers: Human Mobility and Development. 2009. United Nations Development Programme.

Uribe, A. E. M. (2011). Gridded analysis of meteorological variables in nicaragua. The World Bank. Mimeo.

WorldBank (2013). World development report 2014: Risk and opportunity-managing risk for development. Washington, DC: World Bank.

Yang, D. (2008a). Coping with disaster: The impact of hurricanes on international financial flows, 1970-2002. The BE Journal of Economic Analysis \& Policy $8(1)$.

Yang, D. (2008b). International migration, remittances and household investment: Evidence from philippine migrants' exchange rate shocks*. The Economic Journal 118(528), pp. 591-630.

Yang, D. (2011). Migrant remittances. The Journal of Economic Perspectives 25(3), pp. 129-151.

Yang, D. and H. Choi (2007). Are remittances insurance? evidence from rainfall shocks in the philippines. The World Bank Economic Review 21(2), pp. 219-248.

Yang, D. and A. Martínez (2005). Remittances and poverty in migrants' home areas: Evidence from the philippines. In Ç. Özden and M. Schiff (Eds.), International Migration, Remittances and the Brain Drain, pp. 81-123. Washington DC: World Bank. 


\section{Tables and Figures}

Figure 1: Diagram: Young Adults 15-21 years old in 2010

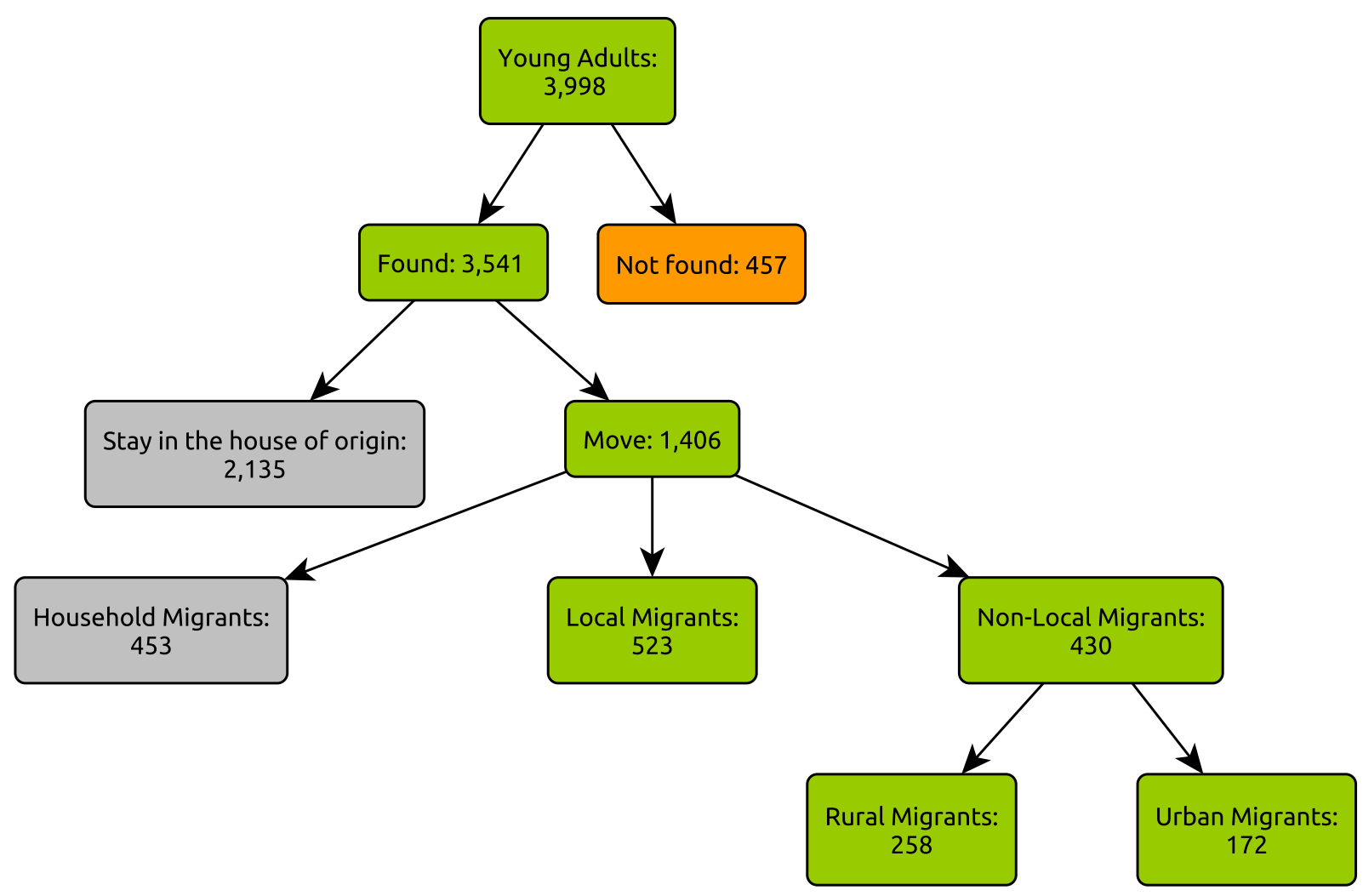

Table 1: Surveyed Individual Migrants by destination: Cohort 15-21 years old in 2010 found and surveyed

\begin{tabular}{|c|c|c|c|c|c|c|}
\hline & \multicolumn{2}{|c|}{ Females } & \multicolumn{2}{|c|}{ Males } & \multicolumn{2}{|c|}{ Total } \\
\hline & No. & $\%$ & No. & $\%$ & No. & $\%$ \\
\hline Local Migrants (rural areas) & 357 & 53.6 & 166 & 57.83 & 523 & 53.97 \\
\hline Non-Local Migrants: & 309 & 46.19 & 121 & 42.16 & 430 & 44.98 \\
\hline Rural & 190 & 28.4 & 68 & 23.69 & 258 & 26.99 \\
\hline Urban & 119 & 17.79 & 53 & 18.47 & 172 & 17.99 \\
\hline Individual Migrants & 666 & & 287 & & 955 & \\
\hline
\end{tabular}

Notes: Household migration includes migrants who moved with the caregiver of children in 2000. Local migrants are defined as those sharing weather shocks with the household of origin. 
Figure 2: Migrants by Destination. Cohort 15-21 years old in 2010

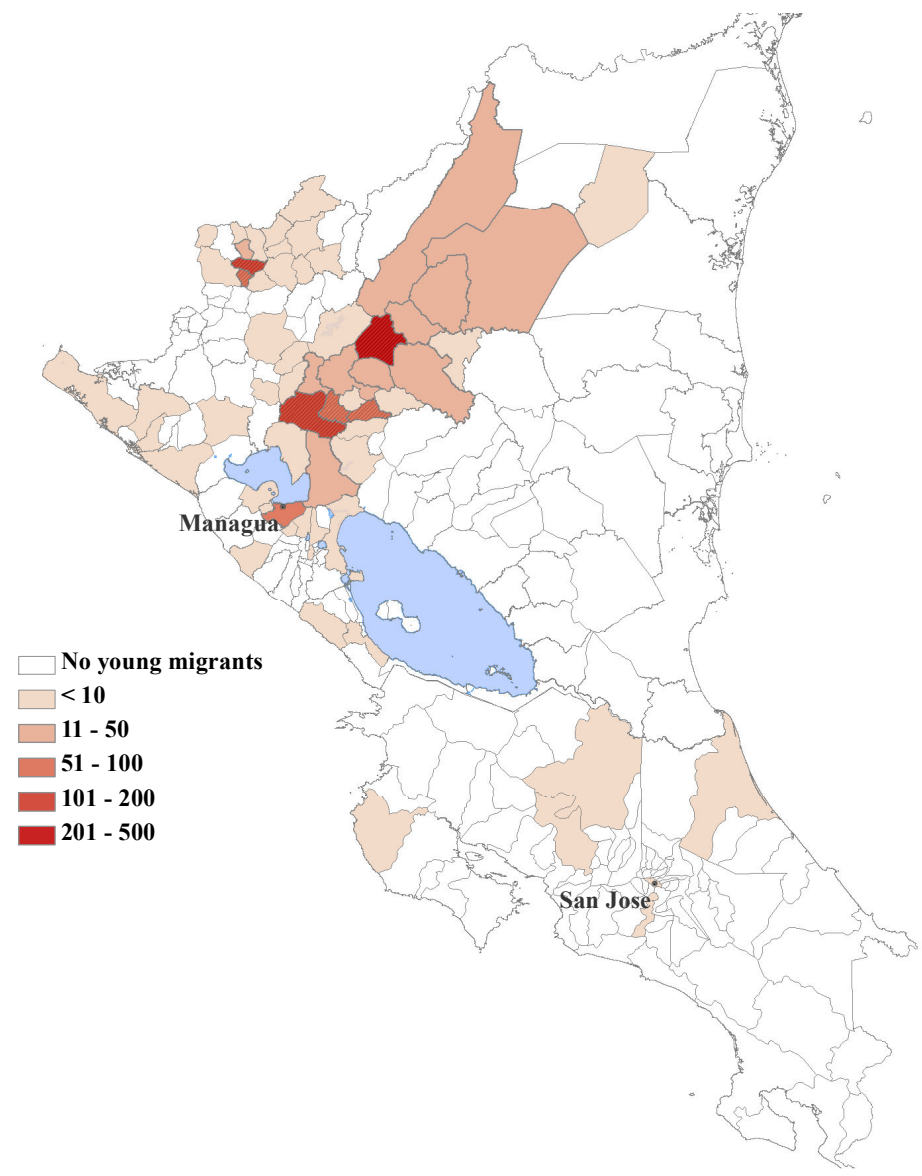

Table 2: Individual Characteristics-2010 by destination. Cohort 15-21 years old in 2010.

\begin{tabular}{|c|c|c|c|c|c|c|}
\hline & \multirow[b]{2}{*}{$\begin{array}{c}\text { Complete } \\
\text { Sample }\end{array}$} & \multirow[b]{2}{*}{ Stayers } & \multirow[b]{2}{*}{$\begin{array}{c}\text { Local } \\
\text { Migrants }\end{array}$} & \multirow[b]{2}{*}{$\begin{array}{c}\text { Non-Local } \\
\text { Migrants }\end{array}$} & \multicolumn{2}{|c|}{ Non-Local Migrants } \\
\hline & & & & & $\begin{array}{c}\text { Rural } \\
\text { Migrants }\end{array}$ & $\begin{array}{c}\text { Urban } \\
\text { Migrants }\end{array}$ \\
\hline Age (Jan, 1st 2010) & 18.03 & $\begin{array}{c}0.00 \\
(0.01)\end{array}$ & $\begin{array}{c}0.01 \\
(0.02)\end{array}$ & $\begin{array}{l}-0.02 \\
(0.02)\end{array}$ & $\begin{array}{l}-0.01 \\
(0.02)\end{array}$ & $\begin{array}{l}-0.04 \\
(0.02)\end{array}$ \\
\hline Marry & 0.25 & $\begin{array}{c}-0.56^{* * *} \\
(0.02)\end{array}$ & $\begin{array}{c}0.54^{* * *} \\
(0.03)\end{array}$ & $\begin{array}{c}0.38^{* * *} \\
(0.03)\end{array}$ & $\begin{array}{c}0.50^{* * *} \\
(0.04)\end{array}$ & $\begin{array}{c}0.13^{* *} \\
(0.06)\end{array}$ \\
\hline Hh head or Spouse & 0.14 & $\begin{array}{c}-0.49^{* * *} \\
(0.02)\end{array}$ & $\begin{array}{c}0.41^{* * *} \\
(0.03)\end{array}$ & $\begin{array}{c}0.40^{* * *} \\
(0.03)\end{array}$ & $\begin{array}{c}0.41^{* * *} \\
(0.04)\end{array}$ & $\begin{array}{c}0.32^{* * * *} \\
(0.04)\end{array}$ \\
\hline Years of school & 6.08 & $\begin{array}{c}0.07 \\
(0.14)\end{array}$ & $\begin{array}{c}-0.60 * * * \\
(0.14)\end{array}$ & $\begin{array}{c}0.65^{* * *} \\
(0.24)\end{array}$ & $\begin{array}{l}-0.27 \\
(0.25)\end{array}$ & $\begin{array}{c}1.94^{* * *} \\
(0.34)\end{array}$ \\
\hline Enrolled & 0.36 & $\begin{array}{c}0.11^{* * *} \\
(0.02)\end{array}$ & $\begin{array}{c}-0.14^{* * *} \\
(0.02)\end{array}$ & $\begin{array}{l}-0.04 \\
(0.04)\end{array}$ & $\begin{array}{c}-0.14^{* * *} \\
(0.04)\end{array}$ & $\begin{array}{l}0.10^{*} \\
(0.06)\end{array}$ \\
\hline Working & 0.92 & $\begin{array}{c}0.04^{* *} \\
(0.01)\end{array}$ & $\begin{array}{c}0.02 \\
(0.02)\end{array}$ & $\begin{array}{c}-0.10^{* * *} \\
(0.03)\end{array}$ & $\begin{array}{l}-0.03 \\
(0.02)\end{array}$ & $\begin{array}{c}-0.18^{* * *} \\
(0.04)\end{array}$ \\
\hline
\end{tabular}

Robust Standard errors, in parentheses, are clustered by comarca. ${ }^{*} \mathrm{p}<0.1,{ }^{* *} \mathrm{p}<0.05,{ }^{* * *} \mathrm{p}<0.01$

Column 1 presents the average value for the complete sample, while Columns 2-5 report the differences in means (standard errors in parentheses) by destination with respect to the rest of the sample. 
Table 3: Descriptive Statistics: Remittances and Transfers. Cohort 15-21 years old in 2010.

\begin{tabular}{|c|c|c|c|c|c|}
\hline & \multirow[b]{2}{*}{$\begin{array}{c}\text { Complete } \\
\text { Sample }\end{array}$} & \multirow[b]{2}{*}{$\begin{array}{c}\text { Local } \\
\text { Migrants }\end{array}$} & \multirow[b]{2}{*}{$\begin{array}{c}\text { Non-Local } \\
\text { Migrants }\end{array}$} & \multicolumn{2}{|c|}{ Non-Local Migrants } \\
\hline & & & & $\begin{array}{c}\text { Rural } \\
\text { Migrants }\end{array}$ & $\begin{array}{c}\text { Urban } \\
\text { Migrants }\end{array}$ \\
\hline Probability to remit & 0.33 & $\begin{array}{l}-0.01 \\
(0.03)\end{array}$ & $\begin{array}{c}0.02 \\
(0.03)\end{array}$ & $\begin{array}{l}-0.02 \\
(0.03)\end{array}$ & $\begin{array}{c}0.06 \\
(0.04)\end{array}$ \\
\hline Probability to receive transfers & 0.34 & $\begin{array}{l}-0.02 \\
(0.04)\end{array}$ & $\begin{array}{c}0.02 \\
(0.04)\end{array}$ & $\begin{array}{c}0.00 \\
(0.03)\end{array}$ & $\begin{array}{c}0.03 \\
(0.05)\end{array}$ \\
\hline Annual value remittances (USD) & 45.90 & $\begin{array}{c}-24.98^{* *} \\
(11.50)\end{array}$ & $\begin{array}{c}30.10^{* *} \\
(14.36)\end{array}$ & $\begin{array}{c}-23.35^{* * * *} \\
(7.43)\end{array}$ & $\begin{array}{c}72.44^{* * *} \\
(21.33)\end{array}$ \\
\hline Annual value transfers (USD) & 46.62 & $\begin{array}{c}-0.41 \\
(18.79)\end{array}$ & $\begin{array}{c}0.30 \\
(18.66)\end{array}$ & $\begin{array}{l}-24.57^{*} \\
(14.00)\end{array}$ & $\begin{array}{c}32.31 \\
(27.06)\end{array}$ \\
\hline Net annual value transfers (USD) & -5.83 & $\begin{array}{c}17.94^{* *} \\
(8.85)\end{array}$ & $\begin{array}{c}-17.82^{* *} \\
(8.70)\end{array}$ & $\begin{array}{c}2.47 \\
(6.76)\end{array}$ & $\begin{array}{c}-39.16^{* * *} \\
(13.18)\end{array}$ \\
\hline \multicolumn{6}{|c|}{ Total Annual Consumption per capita in 2010} \\
\hline Consumption in household of origin & 559.82 & $\begin{array}{c}29.16 \\
(19.68)\end{array}$ & $\begin{array}{l}60.46^{* *} \\
(23.00)\end{array}$ & $\begin{array}{c}11.89 \\
(25.39)\end{array}$ & $\begin{array}{c}124.04^{* * *} \\
(40.07)\end{array}$ \\
\hline Consumption in household of destination & 653.62 & $\begin{array}{l}76.42^{* *} \\
(31.28)\end{array}$ & $\begin{array}{c}659.29^{* * * *} \\
(90.32)\end{array}$ & $\begin{array}{c}188.35^{* * *} \\
(49.17)\end{array}$ & $\begin{array}{c}1271.72^{* * *} \\
(150.32)\end{array}$ \\
\hline
\end{tabular}

Robust Standard errors, in parentheses, are clustered by comarca. ${ }^{*} \mathrm{p}<0.1,{ }^{* *} \mathrm{p}<0.05,{ }^{* * *} \mathrm{p}<0.01$

Column 1 presents the average value for the complete sample, while Columns 2-5 report the differences in means (standard errors in parentheses) by destination with respect to the rest of the sample. 
Figure 3: Distribution Rainfall Shocks (z-score)
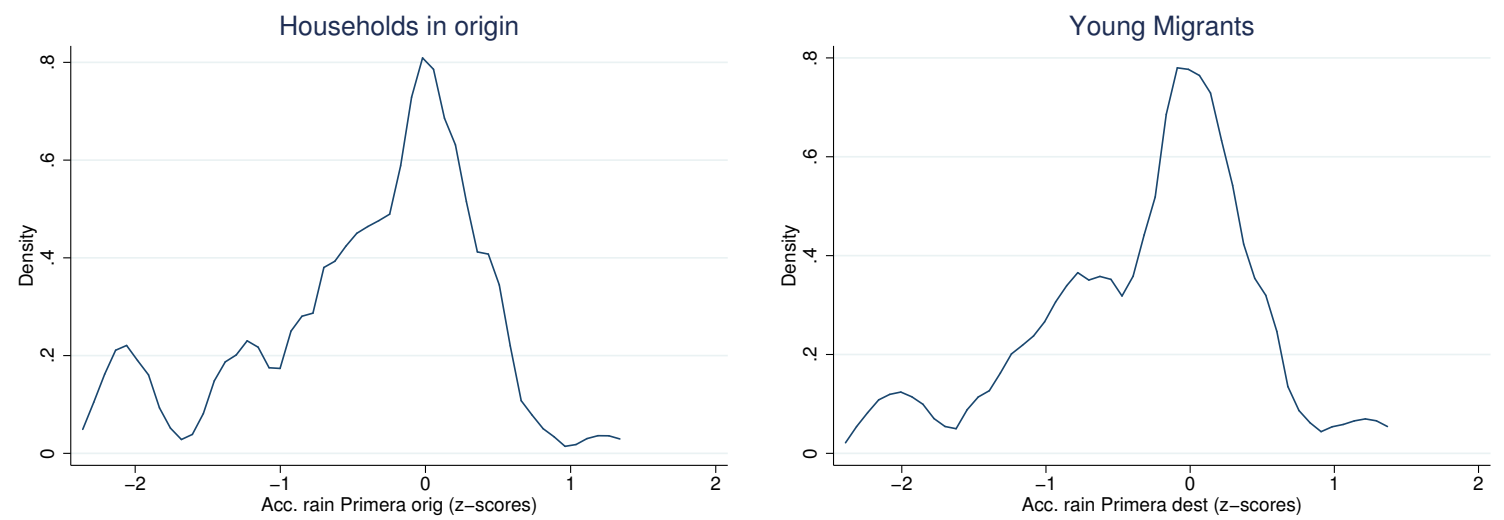

Figure 4: Map of Rainfall Shocks: distribution of Non-Local Migrants (15-21 years old)

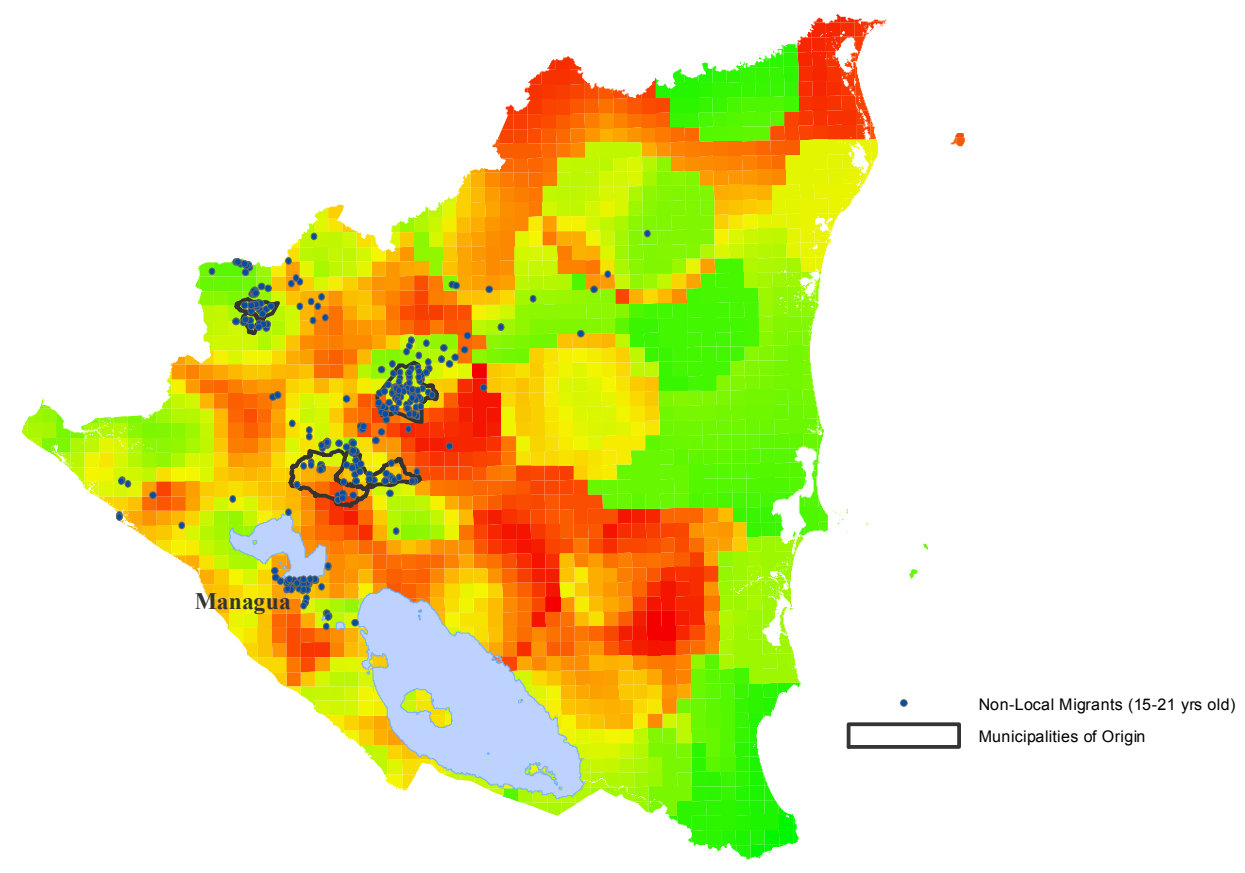


Table 4: Impact of weather shocks on household annual food production and first season harvest.Households in origin of all individuals 15-21 years old (migrants and no migrants)

\begin{tabular}{|c|c|c|c|c|}
\hline Outcome & Sample & Mean & $\begin{array}{c}\text { Rainfall Deficit } \dagger \\
\text { Negative SD }\end{array}$ & $\begin{array}{c}\text { Drought } \ddagger \\
\text { Dummy }\end{array}$ \\
\hline Log Food Production & 1649 & 4.66 & $\begin{array}{c}-0.177^{* * *} \\
(0.06)\end{array}$ & $\begin{array}{c}-0.361^{* * *} \\
(0.1)\end{array}$ \\
\hline Grains produced (USD) & 1649 & 3.05 & $\begin{array}{c}-0.449^{* * *} \\
(0.1)\end{array}$ & $\begin{array}{c}-0.859^{* * *} \\
(0.2)\end{array}$ \\
\hline Grains bought (USD) & 1649 & 2.89 & $\begin{array}{c}0.275^{* *} \\
(0.1)\end{array}$ & $\begin{array}{c}0.566^{* *} \\
(0.2)\end{array}$ \\
\hline \multicolumn{5}{|l|}{ Harvest Final Outcome Primera: } \\
\hline Sale & 1649 & 0.28 & $\begin{array}{c}-0.107^{* * *} \\
(0.03)\end{array}$ & $\begin{array}{c}-0.164^{* * *} \\
(0.05)\end{array}$ \\
\hline Consume & 1649 & 0.79 & $\begin{array}{c}-0.0408^{*} \\
(0.02)\end{array}$ & $\begin{array}{c}-0.108^{* * *} \\
(0.04)\end{array}$ \\
\hline Lost & 1649 & 0.060 & $\begin{array}{c}0.0344^{* *} \\
(0.01)\end{array}$ & $\begin{array}{c}0.0675^{* * *} \\
(0.02)\end{array}$ \\
\hline Area without harvest (sq meters) & 1649 & 638.2 & $\begin{array}{c}195.4 \\
(147.1)\end{array}$ & $\begin{array}{l}507.2^{*} \\
(254.1)\end{array}$ \\
\hline Mean & & & 0.37 & 0.20 \\
\hline
\end{tabular}

$\dagger$ Deviations of accumulated rain between June-July in 2009 from the historical mean divided by the standard deviation for each node multiplied by minus one. Positive values represent rainfall deficits with respect to the historical mean.

$\ddagger$ Drought dummy taking value equal to one if rainfall is equal or less than the historical grid mean minus one standard deviation.

All regressions include household level controls, regional fixed effects, location controls and treatment controls.Values of grains produced and bought are trimmed for $5 \%$ outliers. Robust Standard errors, in parentheses, are clustered by comarca. ${ }^{*} \mathrm{p}<0.1,{ }^{* *} \mathrm{p}<0.05,{ }^{* * *} \mathrm{p}<0.01$ 
Table 5: Impact of weather shocks on annual household income and annual household per capita consumption. Households in Origin of All Individuals 15-21 years old (migrants and no migrants)

\begin{tabular}{lcccc}
\hline & Sample & Mean & $\begin{array}{c}\text { Rainfall Deficit } \dagger \\
\text { Negative SD }\end{array}$ & $\begin{array}{c}\text { Drought } \ddagger \\
\text { Dummy }\end{array}$ \\
\hline $\begin{array}{lccc}\text { Log Household Annual Income } \\
\text { Agricultural Income }\end{array}$ & & & $-0.403^{* * *}$ & $-0.554^{* *}$ \\
& 1648 & 3.65 & $(0.1)$ & $(0.2)$ \\
All sources of Income & 1649 & 6.93 & $-0.149^{* *}$ & $-0.193^{*}$ \\
& & & $(0.06)$ & $(0.1)$ \\
Consumption Smoothing & & & & \\
Log Total Consumption p.c. & 1649 & 6.21 & -0.00303 & 0.00810 \\
& & & $(0.02)$ & $(0.04)$ \\
Log Food Consumption p.c. & 1649 & 5.69 & 0.00224 & 0.0165 \\
& & & $(0.03)$ & $(0.05)$ \\
Log No-Food Consumption p.c. & 1649 & 5.17 & -0.00530 & 0.00817 \\
& & & $(0.02)$ & $(0.04)$ \\
Mean & & & 0.37 & 0.20 \\
\hline
\end{tabular}

†Deviations of accumulated rain between June-July in 2009 from the historical mean divided by the standard deviation for each node multiplied by minus one. Positive values represent rainfall deficits with respect to the historical mean.

$\ddagger$ Drought dummy taking value equal to one if rainfall is equal or less than the historical grid mean minus one standard deviation.

All regressions include household level controls, regional fixed effects, location controls and treatment controls. Robust Standard errors, in parentheses, are clustered by comarca. ${ }^{*} \mathrm{p}<0.1$, $* * \mathrm{p}<0.05, * * * \mathrm{p}<0.01$

Table 6: OLS: Impact of Weather Shocks on Remittances and Transfers Receipts. Non-Local Migrants (15-21 years old)

\begin{tabular}{|c|c|c|c|c|c|}
\hline & \multicolumn{2}{|c|}{ Probability to } & \multicolumn{3}{|c|}{ Total Annual Value (USD) } \\
\hline & $\begin{array}{c}\text { Receive } \\
\text { Transfers }\end{array}$ & Remit & Transfers & Remittances & $\begin{array}{c}\text { Net } \\
\text { Transfers }\end{array}$ \\
\hline Negative Rainfall SD: origin & $\begin{array}{l}-0.06 \\
(0.05)\end{array}$ & $\begin{array}{c}0.03 \\
(0.05)\end{array}$ & $\begin{array}{c}-8.86^{* * *} \\
(2.86)\end{array}$ & $\begin{array}{l}10.22^{*} \\
(5.53)\end{array}$ & $\begin{array}{c}-19.56^{* *} \\
(7.41)\end{array}$ \\
\hline Negative Rainfall SD: destination & $\begin{array}{c}0.04 \\
(0.05)\end{array}$ & $\begin{array}{l}-0.04 \\
(0.04)\end{array}$ & $\begin{array}{c}2.04 \\
(3.72)\end{array}$ & $\begin{array}{l}-6.95 \\
(5.00)\end{array}$ & $\begin{array}{l}8.68 \\
(6.14)\end{array}$ \\
\hline Outcome mean & 0.35 & 0.34 & 12.33 & 18.66 & -5.96 \\
\hline Mean shock origin & 0.36 & 0.36 & 0.36 & 0.36 & 0.36 \\
\hline Mean shock destination & 0.13 & 0.13 & 0.13 & 0.13 & 0.13 \\
\hline Obs & 357 & 348 & 355 & 347 & 346 \\
\hline P-value: $\beta_{o}+\beta_{d}=0$ & 0.709 & 0.916 & 0.140 & 0.440 & 0.087 \\
\hline
\end{tabular}

Notes: Negative Rainfall SD accounts for deviations of accumulated rain between June-July in 2009 from the historical mean divided by the standard deviation for each node multiplied by minus one. Positive values represent rainfall deficits with respect to the historical mean.

All regressions include household and individual level controls, regional fixed effects at origin and at destination, location controls and treatment controls.Dependent values inputed max and min values for the $1 \%$ highest and lowest outliers. Robust Standard errors, in parentheses, are clustered by comarca. ${ }^{*} \mathrm{p}<0.1$, ${ }^{* *} \mathrm{p}<0.05,{ }^{* * *} \mathrm{p}<0.01$ 
Table 7: OLS: Impact of Weather Shocks on Remittances and Transfers Receipts. Non-Local Migrants. Intensive Margin (1521 years old)

\begin{tabular}{lccc}
\hline & \multicolumn{3}{c}{ Intensive Margin } \\
& \multicolumn{3}{c}{ Total Annual Value (USD) } \\
\cline { 2 - 4 } & Transfers & Remittances & $\begin{array}{c}\text { Net } \\
\text { Transfers }\end{array}$ \\
\hline Negative Rainfall SD: origin & $-26.24^{* *}$ & $63.24^{* *}$ & $-72.52^{* * *}$ \\
& $(12.49)$ & $(28.19)$ & $(26.84)$ \\
Negative Rainfall SD: destination & 30.06 & $-61.24^{* *}$ & $62.36^{* *}$ \\
& $(27.67)$ & $(26.58)$ & $(25.73)$ \\
Outcome mean & 45.60 & 61.78 & -9.75 \\
Mean shock origin & 0.36 & 0.36 & 0.36 \\
Mean shock destination & 0.13 & 0.13 & 0.13 \\
Obs & 126 & 119 & 175 \\
\hline
\end{tabular}

Notes: Negative Rainfall SD accounts for deviations of accumulated rain between June-July in 2009 from the historical mean divided by the standard deviation for each node multiplied by minus one. Positive values represent rainfall deficits with respect to the historical mean.

All regressions include household and individual level controls, regional fixed effects at origin and at destination, location controls and treatment controls.Dependent values inputed max and min values for the $1 \%$ highest and lowest outliers. Robust Standard errors, in parentheses, are clustered by comarca. ${ }^{*} \mathrm{p}<0.1,{ }^{* *} \mathrm{p}<0.05$, $* * * \mathrm{p}<0.01$

Table 8: OLS: Impact of Weather Shocks on Remittances and Transfers Receipts. Non-Local Migrants (18-21 years old)

\begin{tabular}{|c|c|c|c|c|c|}
\hline & \multicolumn{2}{|c|}{ Probability to } & \multicolumn{3}{|c|}{ Total Annual Value (USD) } \\
\hline & $\begin{array}{l}\text { Receive } \\
\text { Transfers }\end{array}$ & Remit & Transfers & Remittances & $\begin{array}{c}\text { Net } \\
\text { Transfers }\end{array}$ \\
\hline Negative Rainfall SD: origin & $\begin{array}{c}-0.11^{* *} \\
(0.05)\end{array}$ & $\begin{array}{l}-0.00 \\
(0.04)\end{array}$ & $\begin{array}{c}-13.98^{* * *} \\
(4.83)\end{array}$ & $\begin{array}{c}16.24^{* *} \\
(7.27)\end{array}$ & $\begin{array}{c}-30.48^{* * *} \\
(10.44)\end{array}$ \\
\hline Negative Rainfall SD: destination & $\begin{array}{c}0.05 \\
(0.05)\end{array}$ & $\begin{array}{l}-0.05 \\
(0.06)\end{array}$ & $\begin{array}{c}4.32 \\
(4.57)\end{array}$ & $\begin{array}{c}-12.02 \\
(7.49)\end{array}$ & $\begin{array}{c}16.45^{*} \\
(8.21)\end{array}$ \\
\hline Outcome mean & 0.34 & 0.37 & 12.14 & 24.66 & -12.43 \\
\hline Mean shock origin & 0.39 & 0.39 & 0.39 & 0.39 & 0.39 \\
\hline Mean shock destination & 0.10 & 0.10 & 0.10 & 0.10 & 0.10 \\
\hline Obs & 236 & 236 & 234 & 235 & 234 \\
\hline P-value: $\beta_{o}+\beta_{d}=0$ & 0.284 & 0.429 & 0.065 & 0.548 & 0.096 \\
\hline
\end{tabular}

Notes: Negative Rainfall SD accounts for deviations of accumulated rain between June-July in 2009 from the historical mean divided by the standard deviation for each node multiplied by minus one. Positive values represent rainfall deficits with respect to the historical mean.

All regressions include household and individual level controls, regional fixed effects at origin and at destination, location controls and treatment controls.Dependent values inputed max and min values for the $1 \%$ highest and lowest outliers. Robust Standard errors, in parentheses, are clustered by comarca. ${ }^{*} \mathrm{p}<0.1$, ${ }^{* *} \mathrm{p}<0.05,{ }^{* * *} \mathrm{p}<0.01$ 
Table 9: OLS: Impact of Weather Shocks on Remittances and Transfers Receipts. Local Migrants( 15-21 years old)

\begin{tabular}{|c|c|c|c|c|c|}
\hline & \multicolumn{2}{|c|}{ Probability to } & \multicolumn{3}{|c|}{ Total Annual Value (USD) } \\
\hline & $\begin{array}{l}\text { Receive } \\
\text { Transfers }\end{array}$ & Remit & Transfers & Remittances & $\begin{array}{c}\text { Net } \\
\text { Transfers }\end{array}$ \\
\hline Negative Rainfall SD: origin & $\begin{array}{l}-0.02 \\
(0.04)\end{array}$ & $\begin{array}{c}0.01 \\
(0.04)\end{array}$ & $\begin{array}{c}0.04 \\
(2.23)\end{array}$ & $\begin{array}{l}-2.13 \\
(1.93)\end{array}$ & $\begin{array}{c}2.68 \\
(2.87)\end{array}$ \\
\hline Outcome mean & 0.33 & 0.32 & 9.97 & 9.80 & 0.71 \\
\hline Mean shock origin & 0.29 & 0.29 & 0.29 & 0.29 & 0.29 \\
\hline Obs & 471 & 446 & 468 & 443 & 442 \\
\hline
\end{tabular}

Notes: Negative Rainfall SD accounts for deviations of accumulated rain between June-July in 2009 from the historical mean divided by the standard deviation for each node multiplied by minus one. Positive values represent rainfall deficits with respect to the historical mean.

All regressions include household and individual level controls, regional fixed effects at origin and at destination, location controls and treatment controls.Dependent values inputed max and min values for the $1 \%$ highest and lowest outliers. Robust Standard errors, in parentheses, are clustered by comarca. ${ }^{*} \mathrm{p}<0.1,{ }^{* *} \mathrm{p}<0.05,{ }^{* * *} \mathrm{p}<0.01$

Table 10: OLS: Impact of Weather Shocks on Remittances and Transfers Receipts. Non-Local Migrants by Destination (15-21 years old)

\begin{tabular}{|c|c|c|c|c|c|}
\hline & \multicolumn{2}{|c|}{ Probability to } & \multicolumn{3}{|c|}{ Total Annual Value (USD) } \\
\hline & $\begin{array}{l}\text { Receive } \\
\text { Transfers }\end{array}$ & Remit & Transfers & Remittances & $\begin{array}{c}\text { Net } \\
\text { Transfers }\end{array}$ \\
\hline & \multicolumn{5}{|c|}{ Urban Non-Local Migrants } \\
\hline Negative Rainfall SD: origin & $\begin{array}{c}-0.16^{* *} \\
(0.07)\end{array}$ & $\begin{array}{l}-0.02 \\
(0.05)\end{array}$ & $\begin{array}{c}-18.17^{* *} \\
(7.83)\end{array}$ & $\begin{array}{c}15.87^{* *} \\
(7.30)\end{array}$ & $\begin{array}{c}-34.94^{* * *} \\
(11.84)\end{array}$ \\
\hline Outcome mean & 0.36 & 0.39 & 19.58 & 36.56 & -16.49 \\
\hline Mean shock origin & 0.66 & 0.66 & 0.66 & 0.66 & 0.66 \\
\hline \multirow[t]{2}{*}{ Obs } & 142 & 139 & 141 & 139 & 138 \\
\hline & \multicolumn{5}{|c|}{ Rural Non-Local Migrants } \\
\hline Negative Rainfall SD: origin & $\begin{array}{l}-0.03 \\
(0.08)\end{array}$ & $\begin{array}{c}0.05 \\
(0.07)\end{array}$ & $\begin{array}{l}-6.63 \\
(4.53)\end{array}$ & $\begin{array}{c}1.22 \\
(1.78)\end{array}$ & $\begin{array}{l}-8.13^{*} \\
(4.77)\end{array}$ \\
\hline Negative Rainfall SD: destination & $\begin{array}{c}0.04 \\
(0.06)\end{array}$ & $\begin{array}{l}-0.04 \\
(0.06)\end{array}$ & $\begin{array}{l}1.58 \\
(2.44)\end{array}$ & $\begin{array}{l}-0.79 \\
(2.21)\end{array}$ & $\begin{array}{c}2.45 \\
(3.27)\end{array}$ \\
\hline Outcome mean & 0.34 & 0.31 & 7.79 & 7.32 & 0.66 \\
\hline Mean shock origin & 0.17 & 0.17 & 0.17 & 0.17 & 0.17 \\
\hline Mean shock destination & 0.21 & 0.21 & 0.21 & 0.21 & 0.21 \\
\hline Obs & 215 & 209 & 214 & 208 & 208 \\
\hline P-value: $\beta_{o}+\beta_{d}=0$ & 0.829 & 0.834 & 0.214 & 0.843 & 0.186 \\
\hline
\end{tabular}

Notes: Negative Rainfall SD accounts for deviations of accumulated rain between June-July in 2009 from the historical mean divided by the standard deviation for each node multiplied by minus one. Positive values represent rainfall deficits with respect to the historical mean.

All regressions include household and individual level controls, regional fixed effects at origin and at destination, location controls and treatment controls.Dependent values inputed max and min values for the $1 \%$ highest and lowest outliers. Robust Standard errors, in parentheses, are clustered by comarca. ${ }^{*} \mathrm{p}<0.1$, $* * \mathrm{p}<0.05,{ }^{* * *} \mathrm{p}<0.01$ 
Figure 5: Rural Migrants (15-21 years old). Impact of Negative Rainfall SD at destination on the Value of Transfers Receipts $\left(\beta_{T r}^{d}\right)$

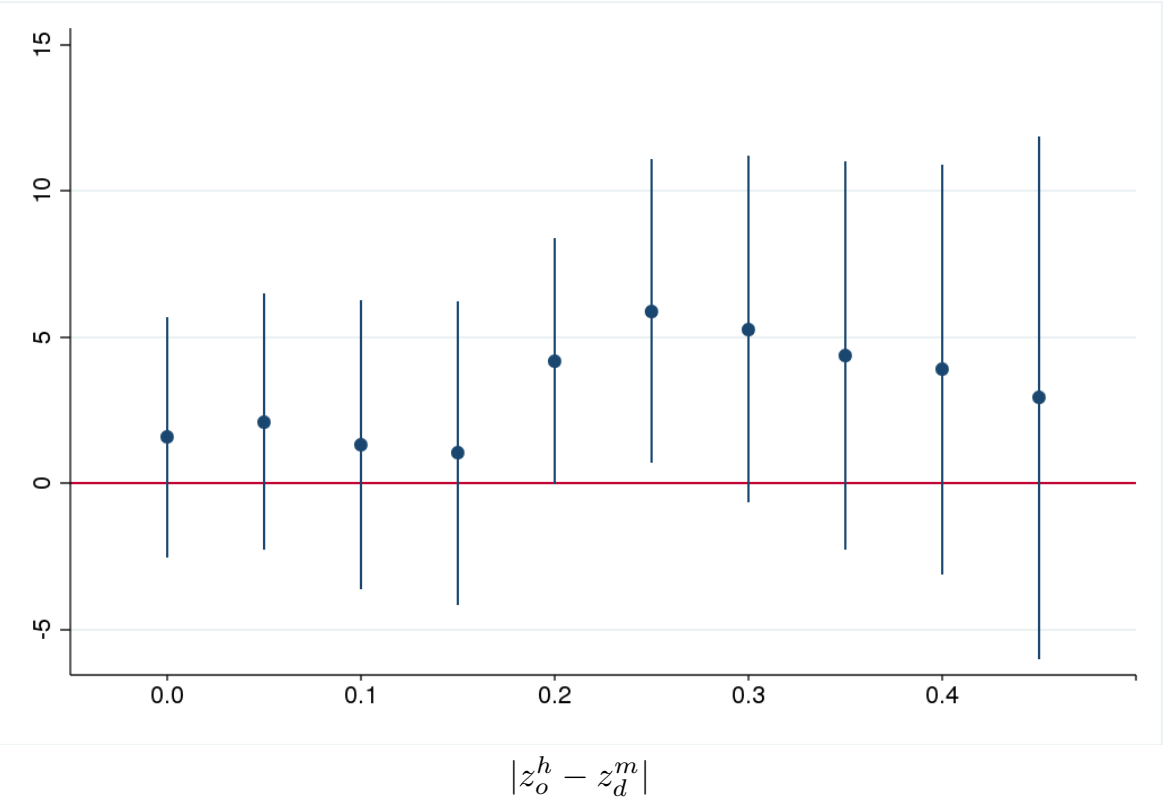

Figure 6: Rural Migrants (15-21 years old). Impact of Negative Rainfall SD at origin on the Value of Remittances Sent $\left(\beta_{R}^{o}\right)$

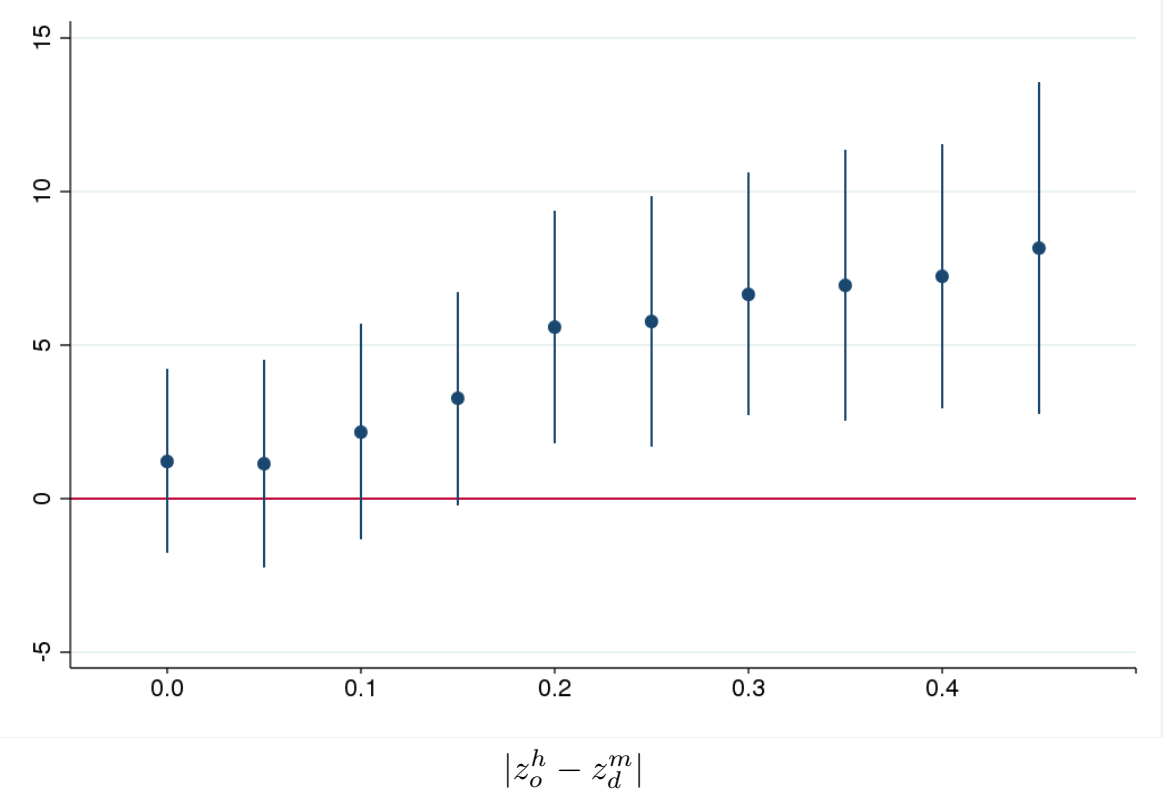

Notes (Figures 5 \& 6): Each figure plots coefficient estimates ( $\beta_{T r}^{d}$ and $\beta_{R}^{o}$ respectively) of running Equation 14 and 15 on the pool of migrants satisfying $\left|z_{o}^{h}-z_{d}^{m}\right|>x$, where $\mathrm{x}$ takes values from 0 to 0.45 in 0.05 intervals. Negative Rainfall SD accounts for deviations of accumulated rain between June-July in 2009 from the historical mean divided by the standard deviation for each node multiplied by minus one. Positive values represent rainfall deficits with respect to the historical mean. Confidence Intervals are set at $90 \%$. All regressions include household and individual level controls, regional fixed effects at origin and at destination, location controls and treatment controls.Dependent values inputed max and min values for the $1 \%$ highest and lowest outliers. Robust Standard errors, in parentheses, are clustered by comarca. 
Table 11: OLS: Impact of Weather Shocks on Remittances and Transfers Receipts. Non-Local Migrants by Migrants' Economic Sector (15-21 years old)

\begin{tabular}{|c|c|c|c|c|c|}
\hline & \multicolumn{2}{|c|}{ Probability to } & \multicolumn{3}{|c|}{ Total Annual Value (USD) } \\
\hline & $\begin{array}{l}\text { Receive } \\
\text { Transfers }\end{array}$ & Remit & Transfers & Remittances & $\begin{array}{c}\text { Net } \\
\text { Transfers }\end{array}$ \\
\hline & \multicolumn{5}{|c|}{ Only Agricultural Activities } \\
\hline Negative Rainfall SD: origin & $\begin{array}{c}0.01 \\
(0.09)\end{array}$ & $\begin{array}{c}0.06 \\
(0.09)\end{array}$ & $\begin{array}{c}-12.83^{*} \\
(7.35)\end{array}$ & $\begin{array}{l}-0.86 \\
(3.13)\end{array}$ & $\begin{array}{c}-11.40 \\
(7.06)\end{array}$ \\
\hline Negative Rainfall SD: destination & $\begin{array}{l}-0.03 \\
(0.06)\end{array}$ & $\begin{array}{l}-0.05 \\
(0.07)\end{array}$ & $\begin{array}{l}-0.31 \\
(3.20)\end{array}$ & $\begin{array}{l}-0.79 \\
(2.44)\end{array}$ & $\begin{array}{l}-0.49 \\
(3.92)\end{array}$ \\
\hline Outcome mean & 0.33 & 0.34 & 9.04 & 9.77 & -0.45 \\
\hline Mean shock origin & 0.28 & 0.28 & 0.28 & 0.28 & 0.28 \\
\hline Mean shock destination & 0.24 & 0.24 & 0.24 & 0.24 & 0.24 \\
\hline Obs & 157 & 152 & 156 & 151 & 151 \\
\hline \multirow[t]{2}{*}{ P-value: $\beta_{o}+\beta_{d}=0$} & 0.737 & 0.927 & 0.043 & 0.642 & 0.093 \\
\hline & \multicolumn{5}{|c|}{ Agricultural and Non-Agricultural Activities } \\
\hline Negative Rainfall SD: origin & $\begin{array}{c}-0.16^{*} \\
(0.08)\end{array}$ & $\begin{array}{c}0.05 \\
(0.08)\end{array}$ & $\begin{array}{c}-15.93^{* *} \\
(7.51)\end{array}$ & $\begin{array}{c}22.81^{* *} \\
(9.26)\end{array}$ & $\begin{array}{c}-38.49^{* * *} \\
(13.37)\end{array}$ \\
\hline Negative Rainfall SD: destination & $\begin{array}{l}0.18^{*} \\
(0.10)\end{array}$ & $\begin{array}{c}0.09 \\
(0.11)\end{array}$ & $\begin{array}{c}5.82 \\
(6.47)\end{array}$ & $\begin{array}{l}-17.80 \\
(13.51)\end{array}$ & $\begin{array}{c}25.49 \\
(19.23)\end{array}$ \\
\hline Outcome mean & 0.35 & 0.40 & 12.31 & 32.66 & -20.15 \\
\hline Mean shock origin & 0.46 & 0.46 & 0.46 & 0.46 & 0.46 \\
\hline Mean shock destination & 0.38 & 0.38 & 0.38 & 0.38 & 0.38 \\
\hline Obs & 139 & 138 & 138 & 138 & 137 \\
\hline P-value: $\beta_{o}+\beta_{d}=0$ & 0.906 & 0.280 & 0.227 & 0.703 & 0.439 \\
\hline
\end{tabular}

Notes: Negative Rainfall SD accounts for deviations of accumulated rain between June-July in 2009 from the historical mean divided by the standard deviation for each node multiplied by minus one. Positive values represent rainfall deficits with respect to the historical mean.

All regressions include household and individual level controls, regional fixed effects at origin and at destination, location controls and treatment controls.Dependent values inputed max and min values for the $1 \%$ highest and lowest outliers. Robust Standard errors, in parentheses, are clustered by comarca. ${ }^{*} \mathrm{p}<0.1$, ${ }^{* *} \mathrm{p}<0.05,{ }^{* * *} \mathrm{p}<0.01$

Table 12: OLS: Impact of Weather Shocks on Remittances and Transfers Receipts. Non-Local Migrants Whom the Head of Household of Origin Works Only on the Agricultural Sector. (15-21 years old)

\begin{tabular}{lccccccc}
\hline & \multicolumn{2}{c}{ Probability } & & \multicolumn{2}{c}{ Total Annual Value (USD) } \\
\cline { 2 - 3 } & $\begin{array}{c}\text { Receive } \\
\text { Transfers }\end{array}$ & Remit & & Transfers & Remittances & $\begin{array}{c}\text { Net } \\
\text { Transfers }\end{array}$ \\
\hline Negative Rainfall SD: origin & -0.07 & 0.08 & & $-9.64^{* *}$ & $18.93^{* *}$ & $-29.37^{* * *}$ \\
& $(0.08)$ & $(0.05)$ & & $(4.12)$ & $(7.68)$ & $(10.55)$ \\
Negative Rainfall SD: destination & 0.07 & -0.02 & & 2.15 & & -6.25 & 7.90 \\
& $(0.07)$ & $(0.06)$ & & $(4.59)$ & & $(5.72)$ & $(7.69)$ \\
Outcome mean & 0.37 & 0.36 & & 13.31 & & 18.01 & -4.24 \\
Mean shock origin & 0.33 & 0.33 & & 0.33 & 0.33 & 0.33 \\
Mean shock destination & 0.13 & 0.13 & & 0.13 & 0.13 & 0.13 \\
Obs & 290 & 282 & & 288 & 281 & 280 \\
P-value: $\beta_{o}+\beta_{d}=0$ & 0.918 & 0.385 & & 0.122 & 0.028 & 0.023 \\
\hline
\end{tabular}

Notes: Negative Rainfall SD accounts for deviations of accumulated rain between June-July in 2009 from the historical mean divided by the standard deviation for each node multiplied by minus one. Positive values represent rainfall deficits with respect to the historical mean.

All regressions include household and individual level controls, regional fixed effects at origin and at destination, location controls and treatment controls.Dependent values inputed max and min values for the $1 \%$ highest and lowest outliers. Robust Standard errors, in parentheses, are clustered by comarca. ${ }^{*} \mathrm{p}<0.1$ ${ }^{* *} \mathrm{p}<0.05,{ }^{* * *} \mathrm{p}<0.01$ 
Table 13: OLS: Impact of Weather Shocks on Remittances and Transfers Receipts. Non-Local Migrants Whom the Head of Household of Origin Works Only on the Agricultural Sector By Migrants' Economic Sector (15-21 years old)

\begin{tabular}{|c|c|c|c|c|c|}
\hline & \multicolumn{2}{|c|}{ Probability to } & \multicolumn{3}{|c|}{ Total Annual Value (USD) } \\
\hline & $\begin{array}{l}\text { Receive } \\
\text { Transfers }\end{array}$ & Remit & Transfers & Remittances & $\begin{array}{c}\text { Net } \\
\text { Transfers }\end{array}$ \\
\hline & \multicolumn{5}{|c|}{ Only Agricultural Activities } \\
\hline Negative Rainfall SD: origin & $\begin{array}{c}0.12 \\
(0.10)\end{array}$ & $\begin{array}{c}0.16 \\
(0.11)\end{array}$ & $\begin{array}{l}-8.31 \\
(7.02)\end{array}$ & $\begin{array}{l}6.57^{*} \\
(3.34)\end{array}$ & $\begin{array}{c}-12.82 \\
(7.99)\end{array}$ \\
\hline Negative Rainfall SD: destination & $\begin{array}{l}-0.03 \\
(0.07)\end{array}$ & $\begin{array}{l}-0.04 \\
(0.08)\end{array}$ & $\begin{array}{l}-0.58 \\
(4.38)\end{array}$ & $\begin{array}{l}-1.71 \\
(2.79)\end{array}$ & $\begin{array}{l}-0.88 \\
(5.29)\end{array}$ \\
\hline Outcome mean & 0.34 & 0.36 & 9.72 & 9.35 & 0.73 \\
\hline Mean shock origin & 0.26 & 0.26 & 0.26 & 0.26 & 0.26 \\
\hline Mean shock destination & 0.25 & 0.25 & 0.25 & 0.25 & 0.25 \\
\hline Obs & 132 & 127 & 131 & 126 & 126 \\
\hline \multirow[t]{2}{*}{ P-value: $\beta_{o}+\beta_{d}=0$} & 0.366 & 0.257 & 0.159 & 0.244 & 0.070 \\
\hline & \multicolumn{5}{|c|}{ Agricultural and Non-Agricultural Activities } \\
\hline Negative Rainfall SD: origin & $\begin{array}{c}-0.32^{* * *} \\
(0.09)\end{array}$ & $\begin{array}{c}0.14 \\
(0.11)\end{array}$ & $\begin{array}{c}-26.62^{* * *} \\
(7.75)\end{array}$ & $\begin{array}{c}44.00^{* *} \\
(16.27)\end{array}$ & $\begin{array}{c}-70.55^{* * *} \\
(20.00)\end{array}$ \\
\hline Negative Rainfall SD: destination & $\begin{array}{c}0.23^{* *} \\
(0.10)\end{array}$ & $\begin{array}{c}0.15 \\
(0.16)\end{array}$ & $\begin{array}{c}3.88 \\
(6.06)\end{array}$ & $\begin{array}{l}-13.83 \\
(14.33)\end{array}$ & $\begin{array}{c}18.47 \\
(17.98)\end{array}$ \\
\hline Outcome mean & 0.38 & 0.44 & 13.63 & 32.87 & -18.99 \\
\hline Mean shock origin & 0.39 & 0.39 & 0.39 & 0.39 & 0.39 \\
\hline Mean shock destination & 0.35 & 0.35 & 0.35 & 0.35 & 0.35 \\
\hline Obs & 113 & 112 & 112 & 112 & 111 \\
\hline P-value: $\beta_{o}+\beta_{d}=0$ & 0.508 & 0.159 & 0.020 & 0.157 & 0.034 \\
\hline
\end{tabular}

Notes: Negative Rainfall SD accounts for deviations of accumulated rain between June-July in 2009 from the historical mean divided by the standard deviation for each node multiplied by minus one. Positive values represent rainfall deficits with respect to the historical mean.

All regressions include household and individual level controls, regional fixed effects at origin and at destination, location controls and treatment controls.Dependent values inputed max and min values for the $1 \%$ highest and lowest outliers. Robust Standard errors, in parentheses, are clustered by comarca. ${ }^{*} \mathrm{p}<0.1$, $* * \mathrm{p}<0.05,{ }^{* * *} \mathrm{p}<0.01$ 
Table 14: OLS: Impact of Weather Shocks on Remittances and Transfers Receipts. Non-Local Migrants Found and Not Found (15-21 years old)

\begin{tabular}{|c|c|c|c|c|c|}
\hline & \multicolumn{2}{|c|}{ Probability to } & \multicolumn{3}{|c|}{ Total Annual Value (USD) } \\
\hline & $\begin{array}{l}\text { Receive } \\
\text { Transfers }\end{array}$ & Remit & Transfers & Remittances & $\begin{array}{c}\text { Net } \\
\text { Transfers }\end{array}$ \\
\hline & \multicolumn{5}{|c|}{ Nicaragua } \\
\hline Negative Rainfall SD: origin & $\begin{array}{l}-0.03 \\
(0.04)\end{array}$ & $\begin{array}{c}0.04 \\
(0.04)\end{array}$ & $\begin{array}{c}-3.74^{* *} \\
(1.72)\end{array}$ & $\begin{array}{c}6.64 \\
(4.19)\end{array}$ & $\begin{array}{c}-10.04^{*} \\
(5.01)\end{array}$ \\
\hline Negative Rainfall SD: destination & $\begin{array}{c}0.04 \\
(0.04)\end{array}$ & $\begin{array}{l}-0.01 \\
(0.03)\end{array}$ & $\begin{array}{c}0.94 \\
(1.94)\end{array}$ & $\begin{array}{l}-2.89 \\
(4.44)\end{array}$ & $\begin{array}{c}3.45 \\
(4.62)\end{array}$ \\
\hline Outcome mean & 0.31 & 0.33 & 8.82 & 21.25 & -12.66 \\
\hline Mean shock origin & 0.36 & 0.36 & 0.36 & 0.36 & 0.36 \\
\hline Mean shock destination & 0.19 & 0.19 & 0.19 & 0.19 & 0.19 \\
\hline Obs & 466 & 450 & 463 & 449 & 447 \\
\hline \multirow[t]{2}{*}{ P-value: $\beta_{o}+\beta_{d}=0$} & 0.816 & 0.579 & 0.343 & 0.359 & 0.194 \\
\hline & \multicolumn{5}{|c|}{ Migrants: Nicaragua and Costa Rica } \\
\hline Negative Rainfall SD: origin & $\begin{array}{l}-0.02 \\
(0.04)\end{array}$ & $\begin{array}{c}0.04 \\
(0.04)\end{array}$ & $\begin{array}{l}-3.10^{*} \\
(1.65)\end{array}$ & $\begin{array}{c}6.39 \\
(4.62)\end{array}$ & $\begin{array}{l}-9.46^{*} \\
(5.32)\end{array}$ \\
\hline Negative Rainfall SD: destination & $\begin{array}{c}0.04 \\
(0.04)\end{array}$ & $\begin{array}{l}-0.01 \\
(0.03)\end{array}$ & $\begin{array}{c}0.71 \\
(1.92)\end{array}$ & $\begin{array}{c}-1.87 \\
(4.42)\end{array}$ & $\begin{array}{c}2.36 \\
(4.48)\end{array}$ \\
\hline Outcome mean & 0.30 & 0.34 & 8.67 & 24.40 & -16.17 \\
\hline Mean shock origin & 0.35 & 0.35 & 0.35 & 0.35 & 0.35 \\
\hline Mean shock destination & 0.18 & 0.18 & 0.18 & 0.18 & 0.18 \\
\hline Obs & 488 & 472 & 485 & 471 & 469 \\
\hline P-value: $\beta_{o}+\beta_{d}=0$ & 0.694 & 0.556 & 0.400 & 0.313 & 0.198 \\
\hline
\end{tabular}

Notes: Negative Rainfall SD accounts for deviations of accumulated rain between June-July in 2009 from the historical mean divided by the standard deviation for each node multiplied by minus one. Positive values represent rainfall deficits with respect to the historical mean.

All regressions include household and individual level controls, regional fixed effects at origin and at destination, location controls and treatment controls.Dependent values inputed max and min values for the $1 \%$ highest and lowest outliers. Robust Standard errors, in parentheses, are clustered by comarca. ${ }^{*} \mathrm{p}<0.1$, ${ }^{* *} \mathrm{p}<0.05,{ }^{* * *} \mathrm{p}<0.01$ 
Table 15: OLS: Impact of Weather Shocks on Remittances and Transfers Receipts. Non-Local Migrants. Civil Status (15-21 years old)

\begin{tabular}{|c|c|c|c|c|c|}
\hline & \multicolumn{2}{|c|}{ Probability to } & \multicolumn{3}{|c|}{ Total Annual Value (USD) } \\
\hline & $\begin{array}{l}\text { Receive } \\
\text { Transfers }\end{array}$ & Remit & Transfers & Remittances & $\begin{array}{c}\text { Net } \\
\text { Transfers }\end{array}$ \\
\hline & \multicolumn{5}{|c|}{ No Married Migrants } \\
\hline Negative Rainfall SD: origin & $\begin{array}{l}-0.03 \\
(0.06)\end{array}$ & $\begin{array}{l}-0.02 \\
(0.05)\end{array}$ & $\begin{array}{c}-8.56^{* *} \\
(3.21)\end{array}$ & $\begin{array}{c}0.98 \\
(5.22)\end{array}$ & $\begin{array}{c}-10.10 \\
(6.02)\end{array}$ \\
\hline No Married*Shock origin & $\begin{array}{l}-0.07 \\
(0.09)\end{array}$ & $\begin{array}{l}0.12^{*} \\
(0.07)\end{array}$ & $\begin{array}{l}-2.59 \\
(5.49)\end{array}$ & $\begin{array}{c}21.09 \\
(14.26)\end{array}$ & $\begin{array}{l}-23.69 \\
(16.72)\end{array}$ \\
\hline Negative Rainfall SD: destination & $\begin{array}{c}0.01 \\
(0.05)\end{array}$ & $\begin{array}{c}0.01 \\
(0.05)\end{array}$ & $\begin{array}{c}5.49 \\
(3.95)\end{array}$ & $\begin{array}{c}3.65 \\
(3.94)\end{array}$ & $\begin{array}{l}1.88 \\
(5.38)\end{array}$ \\
\hline No Married*Shock destination & $\begin{array}{c}0.10 \\
(0.14)\end{array}$ & $\begin{array}{l}-0.19 \\
(0.13)\end{array}$ & $\begin{array}{l}-10.12 \\
(6.04)\end{array}$ & $\begin{array}{c}-30.17^{* *} \\
(11.92)\end{array}$ & $\begin{array}{c}18.35 \\
(12.57)\end{array}$ \\
\hline No Married & $\begin{array}{l}-0.03 \\
(0.08)\end{array}$ & $\begin{array}{l}-0.06 \\
(0.06)\end{array}$ & $\begin{array}{c}8.99 \\
(6.58)\end{array}$ & $\begin{array}{l}10.75^{*} \\
(6.32)\end{array}$ & $\begin{array}{c}-1.69 \\
(10.38)\end{array}$ \\
\hline Outcome mean & 0.35 & 0.34 & 12.33 & 18.66 & -5.96 \\
\hline Mean shock origin & 0.36 & 0.36 & 0.36 & 0.36 & 0.36 \\
\hline Mean shock destination & 0.13 & 0.13 & 0.13 & 0.13 & 0.13 \\
\hline Obs & 357 & 348 & 355 & 347 & 346 \\
\hline P-value: shock orig & 0.358 & 0.244 & 0.009 & 0.134 & 0.018 \\
\hline \multirow[t]{2}{*}{ P-value: shock dest } & 0.723 & 0.213 & 0.203 & 0.047 & 0.208 \\
\hline & \multicolumn{5}{|c|}{ No Hh head or Spouse } \\
\hline Negative Rainfall SD: origin & $\begin{array}{l}-0.01 \\
(0.06)\end{array}$ & $\begin{array}{l}-0.00 \\
(0.05)\end{array}$ & $\begin{array}{c}-7.95^{* *} \\
(3.56)\end{array}$ & $\begin{array}{c}7.13 \\
(4.44)\end{array}$ & $\begin{array}{c}-15.64^{* *} \\
(6.26)\end{array}$ \\
\hline No Hh Head*Shock origin & $\begin{array}{l}-0.11 \\
(0.07)\end{array}$ & $\begin{array}{c}0.07 \\
(0.08)\end{array}$ & $\begin{array}{l}-2.72 \\
(6.01)\end{array}$ & $\begin{array}{c}6.04 \\
(9.91)\end{array}$ & $\begin{array}{c}-8.81 \\
(12.33)\end{array}$ \\
\hline Negative Rainfall SD: destination & $\begin{array}{c}0.03 \\
(0.06)\end{array}$ & $\begin{array}{c}0.02 \\
(0.06)\end{array}$ & $\begin{array}{c}6.20 \\
(4.87)\end{array}$ & $\begin{array}{l}-2.40 \\
(5.02)\end{array}$ & $\begin{array}{l}8.56 \\
(6.09)\end{array}$ \\
\hline No Hh Head*Shock destination & $\begin{array}{c}0.02 \\
(0.09)\end{array}$ & $\begin{array}{l}-0.14^{*} \\
(0.08)\end{array}$ & $\begin{array}{l}-8.21 \\
(6.03)\end{array}$ & $\begin{array}{l}-9.29 \\
(5.75)\end{array}$ & $\begin{array}{c}0.43 \\
(8.44)\end{array}$ \\
\hline No hh head & $\begin{array}{l}-0.08 \\
(0.06)\end{array}$ & $\begin{array}{l}-0.11 \\
(0.07)\end{array}$ & $\begin{array}{c}1.14 \\
(4.60)\end{array}$ & $\begin{array}{c}4.29 \\
(4.57)\end{array}$ & $\begin{array}{l}-3.42 \\
(6.85)\end{array}$ \\
\hline Outcome mean & 0.35 & 0.34 & 12.33 & 18.66 & -5.96 \\
\hline Mean shock origin & 0.36 & 0.36 & 0.36 & 0.36 & 0.36 \\
\hline Mean shock destination & 0.13 & 0.13 & 0.13 & 0.13 & 0.13 \\
\hline Obs & 357 & 348 & 355 & 347 & 346 \\
\hline P-value: shock orig & 0.104 & 0.682 & 0.010 & 0.155 & 0.022 \\
\hline P-value: shock dest & 0.707 & 0.149 & 0.364 & 0.164 & 0.331 \\
\hline
\end{tabular}

Notes: Negative Rainfall SD accounts for deviations of accumulated rain between June-July in 2009 from the historical mean divided by the standard deviation for each node multiplied by minus one. Positive values represent rainfall deficits with respect to the historical mean.

All regressions include household and individual level controls, regional fixed effects at origin and at destination, location controls and treatment controls.Dependent values inputed max and min values for the $1 \%$ highest and lowest outliers. Robust Standard errors, in parentheses, are clustered by comarca. ${ }^{*} \mathrm{p}<0.1$, $* * \mathrm{p}<0.05,{ }^{* * *} \mathrm{p}<0.01$ 
Table 16: OLS: Impact of Weather Shocks on Remittances and Transfers Receipts. Non-Local Migrants. Enrolled in School (15-21 years old)

\begin{tabular}{|c|c|c|c|c|c|}
\hline & \multicolumn{2}{|c|}{ Probability to } & \multicolumn{3}{|c|}{ Total Annual Value (USD) } \\
\hline & $\begin{array}{l}\text { Receive } \\
\text { Transfers }\end{array}$ & Remit & Transfers & Remittances & $\begin{array}{c}\text { Net } \\
\text { Transfers }\end{array}$ \\
\hline Negative Rainfall SD: origin & $\begin{array}{l}-0.10 \\
(0.06)\end{array}$ & $\begin{array}{c}0.02 \\
(0.06)\end{array}$ & $\begin{array}{c}-10.81^{* * *} \\
(2.95)\end{array}$ & $\begin{array}{l}14.54 \\
(9.29)\end{array}$ & $\begin{array}{c}-25.84^{* *} \\
(11.01)\end{array}$ \\
\hline Enrolled*Shock origin & $\begin{array}{c}0.09 \\
(0.09)\end{array}$ & $\begin{array}{c}0.06 \\
(0.08)\end{array}$ & $\begin{array}{c}3.45 \\
(5.47)\end{array}$ & $\begin{array}{c}-10.51 \\
(10.79)\end{array}$ & $\begin{array}{c}13.55 \\
(10.78)\end{array}$ \\
\hline Negative Rainfall SD: destination & $\begin{array}{c}0.04 \\
(0.06)\end{array}$ & $\begin{array}{l}-0.03 \\
(0.05)\end{array}$ & $\begin{array}{c}4.46 \\
(3.91)\end{array}$ & $\begin{array}{l}-9.12 \\
(7.47)\end{array}$ & $\begin{array}{l}13.46^{*} \\
(7.64)\end{array}$ \\
\hline Enrolled*Shock destination & $\begin{array}{c}0.10 \\
(0.16)\end{array}$ & $\begin{array}{l}-0.03 \\
(0.14)\end{array}$ & $\begin{array}{l}-6.67 \\
(6.38)\end{array}$ & $\begin{array}{c}3.66 \\
(9.02)\end{array}$ & $\begin{array}{l}-11.89 \\
(10.54)\end{array}$ \\
\hline Enrolled in school & $\begin{array}{c}0.05 \\
(0.08)\end{array}$ & $\begin{array}{l}-0.06 \\
(0.07)\end{array}$ & $\begin{array}{l}10.81 \\
(6.98)\end{array}$ & $\begin{array}{c}1.86 \\
(4.93)\end{array}$ & $\begin{array}{l}10.26 \\
(9.00)\end{array}$ \\
\hline Outcome mean & 0.35 & 0.34 & 12.33 & 18.66 & -5.96 \\
\hline Mean interaction & 0.29 & 0.29 & 0.29 & 0.29 & 0.29 \\
\hline Mean shock origin & 0.36 & 0.36 & 0.36 & 0.36 & 0.36 \\
\hline Mean shock destination & 0.13 & 0.13 & 0.13 & 0.13 & 0.13 \\
\hline Obs & 356 & 347 & 354 & 346 & 345 \\
\hline P-value: shock orig & 0.291 & 0.587 & 0.002 & 0.193 & 0.031 \\
\hline P-value: shock dest & 0.373 & 0.710 & 0.429 & 0.431 & 0.202 \\
\hline
\end{tabular}

Notes: Negative Rainfall SD accounts for deviations of accumulated rain between June-July in 2009 from the historical mean divided by the standard deviation for each node multiplied by minus one. Positive values represent rainfall deficits with respect to the historical mean.

All regressions include household and individual level controls, regional fixed effects at origin and at destination, location controls and treatment controls.Dependent values inputed max and min values for the $1 \%$ highest and lowest outliers. Robust Standard errors, in parentheses, are clustered by comarca. ${ }^{*} \mathrm{p}<0.1$, $* * \mathrm{p}<0.05,{ }^{* * *} \mathrm{p}<0.01$

Table 17: OLS: Impact of Weather Shocks on Remittances and Transfers Receipts. Non-Local Migrants (22-30 years old)

\begin{tabular}{|c|c|c|c|c|c|}
\hline & \multicolumn{2}{|c|}{ Probability to } & \multicolumn{3}{|c|}{ Total Annual Value (USD) } \\
\hline & $\begin{array}{c}\text { Receive } \\
\text { Transfers }\end{array}$ & Remit & Transfers & Remittances & $\begin{array}{c}\text { Net } \\
\text { Transfers }\end{array}$ \\
\hline & \multicolumn{5}{|c|}{ Migrants: Nicaragua } \\
\hline Negative Rainfall SD: origin & $\begin{array}{l}-0.01 \\
(0.03)\end{array}$ & $\begin{array}{l}-0.00 \\
(0.03)\end{array}$ & $\begin{array}{l}-0.18 \\
(1.23)\end{array}$ & $\begin{array}{l}6.31^{*} \\
(3.71)\end{array}$ & $\begin{array}{l}-6.46^{*} \\
(3.48)\end{array}$ \\
\hline Negative Rainfall SD: destination & $\begin{array}{l}-0.01 \\
(0.03)\end{array}$ & $\begin{array}{l}-0.04 \\
(0.04)\end{array}$ & $\begin{array}{l}-0.66 \\
(0.96)\end{array}$ & $\begin{array}{l}-5.68^{*} \\
(3.32)\end{array}$ & $\begin{array}{l}5.33^{*} \\
(3.16)\end{array}$ \\
\hline Outcome mean & 0.29 & 0.41 & 7.77 & 32.06 & -23.90 \\
\hline Mean shock origin & 0.43 & 0.43 & 0.43 & 0.43 & 0.43 \\
\hline Mean shock destination & 0.27 & 0.27 & 0.27 & 0.27 & 0.27 \\
\hline Obs & 896 & 893 & 893 & 891 & 889 \\
\hline \multirow[t]{2}{*}{ P-value: $\beta_{o}+\beta_{d}=0$} & 0.605 & 0.213 & 0.517 & 0.890 & 0.787 \\
\hline & \multicolumn{5}{|c|}{ Migrants: Nicaragua and Costa Rica } \\
\hline Negative Rainfall SD: origin & $\begin{array}{c}0.00 \\
(0.03)\end{array}$ & $\begin{array}{c}0.00 \\
(0.03)\end{array}$ & $\begin{array}{l}-0.28 \\
(1.07)\end{array}$ & $\begin{array}{c}7.16 \\
(4.72)\end{array}$ & $\begin{array}{l}-7.52^{*} \\
(4.14)\end{array}$ \\
\hline Negative Rainfall SD: destination & $\begin{array}{l}-0.01 \\
(0.03)\end{array}$ & $\begin{array}{l}-0.04 \\
(0.04)\end{array}$ & $\begin{array}{l}-0.76 \\
(0.93)\end{array}$ & $\begin{array}{c}-8.54^{* *} \\
(4.13)\end{array}$ & $\begin{array}{l}8.09^{*} \\
(4.06)\end{array}$ \\
\hline P-value: $\beta_{o}+\beta_{d}=0$ & 0.739 & 0.267 & 0.385 & 0.797 & 0.908 \\
\hline Outcome mean & 0.27 & 0.43 & 7.08 & 42.32 & -34.86 \\
\hline Mean shock origin & 0.43 & 0.43 & 0.43 & 0.43 & 0.43 \\
\hline Mean shock destination & 0.24 & 0.24 & 0.24 & 0.24 & 0.24 \\
\hline Obs & 1024 & 1021 & 1016 & 1019 & 1012 \\
\hline
\end{tabular}

Notes: Negative Rainfall SD accounts for deviations of accumulated rain between June-July in 2009 from the historical mean divided by the standard deviation for each node multiplied by minus one. Positive values represent rainfall deficits with respect to the historical mean.

All regressions include household and individual level controls, regional fixed effects at origin and at destination, location controls and treatment controls.Dependent values inputed max and min values for the $1 \%$ highest and lowest outliers. Robust Standard errors, in parentheses, are clustered by comarca. ${ }^{*} \mathrm{p}<0.1$, $* * \mathrm{p}<0.05, * * * \mathrm{p}<0.01$ 
Table 18: Impact of weather shocks on household assets and livestocks. Households in Original Communities

\begin{tabular}{|c|c|c|c|c|}
\hline \multirow[b]{2}{*}{ Outcome } & \multicolumn{2}{|c|}{$\begin{array}{c}\text { Households } \\
\text { Receiving Remittances }\end{array}$} & \multicolumn{2}{|c|}{$\begin{array}{c}\text { Household } \\
\text { Not Receiving Remittances }\end{array}$} \\
\hline & Mean & $\begin{array}{l}\text { Drought } \dagger \\
\text { dummy }\end{array}$ & Mean & $\begin{array}{l}\text { Drought } \dagger \\
\text { dummy }\end{array}$ \\
\hline \multicolumn{5}{|l|}{ Assets } \\
\hline Index assets: use & 0.13 & $\begin{array}{l}0.0317 \\
(0.14)\end{array}$ & -0.0064 & $\begin{array}{r}-0.0931 \\
(0.087)\end{array}$ \\
\hline Index assets: own & 0.091 & $\begin{array}{c}-0.0799 \\
(0.12)\end{array}$ & -0.013 & $\begin{array}{c}-0.131^{* *} \\
(0.061)\end{array}$ \\
\hline \multicolumn{5}{|l|}{ Livestock } \\
\hline TLU Livestock: 2009 & 0.56 & $\begin{array}{l}-0.0444 \\
(0.071)\end{array}$ & 0.51 & $\begin{array}{l}-0.0457 \\
(0.029)\end{array}$ \\
\hline Numb. pigs & 0.81 & $\begin{array}{c}-0.0770 \\
(0.15)\end{array}$ & 0.84 & $\begin{array}{c}-0.224^{* *} \\
(0.10)\end{array}$ \\
\hline Numb. chickens & 10.4 & $\begin{array}{l}-1.177 \\
(1.08)\end{array}$ & 9.86 & $\begin{array}{c}-2.042^{* *} \\
(0.87)\end{array}$ \\
\hline Numb. cows & 1.81 & $\begin{array}{r}-0.138 \\
(0.57)\end{array}$ & 1.69 & $\begin{array}{l}-0.729 \\
(0.48)\end{array}$ \\
\hline Numb. goats & 0.095 & $\begin{array}{l}0.0671 \\
(0.075)\end{array}$ & 0.12 & $\begin{array}{r}-0.0392 \\
(0.038)\end{array}$ \\
\hline Obs. & & 484 & & 1877 \\
\hline
\end{tabular}

$\dagger$ Drought dummy taking value equal to one if rainfall is equal or less than the historical grid mean minus one standard deviation.

All regressions include household level controls, regional fixed effects, location controls and treatment controls. Robust Standard errors, in parentheses, are clustered by comarca. ${ }^{*} \mathrm{p}<0.1$, $* * \mathrm{p}<0.05, * * * \mathrm{p}<0.01$

Households receiving remittances from migrants between 15 and 30 years old in 2010 living in other communities 
Table 19: Impact of weather shocks on economic activities. Households in Original Communities

\begin{tabular}{|c|c|c|c|c|}
\hline \multirow[b]{2}{*}{ Outcome } & \multicolumn{2}{|c|}{$\begin{array}{c}\text { Households } \\
\text { Receiving Remittances }\end{array}$} & \multicolumn{2}{|c|}{$\begin{array}{c}\text { Household } \\
\text { Not Receiving Remittances }\end{array}$} \\
\hline & Mean & $\begin{array}{c}\text { Drought } \dagger \\
\text { dummy }\end{array}$ & Mean & $\begin{array}{c}\text { Drought } \dagger \\
\text { dummy }\end{array}$ \\
\hline \multicolumn{5}{|l|}{ Seasonal Migration } \\
\hline Income from seasonal migration & 394.0 & $\begin{array}{l}-22.76 \\
(101.7)\end{array}$ & 489.9 & $\begin{array}{l}36.16 \\
(56.8)\end{array}$ \\
\hline Share of adults temp mig & 0.24 & $\begin{array}{c}0.00646 \\
(0.024)\end{array}$ & 0.21 & $\begin{array}{r}-0.0202 \\
(0.016)\end{array}$ \\
\hline \multicolumn{5}{|c|}{ Share of household members: Economic Activities } \\
\hline Agric. self-employed & 0.80 & $\begin{array}{r}-0.0202 \\
(0.035)\end{array}$ & 0.76 & $\begin{array}{c}0.000164 \\
(0.025)\end{array}$ \\
\hline Agric. wage-employed & 0.31 & $\begin{array}{l}0.0130 \\
(0.030)\end{array}$ & 0.32 & $\begin{array}{c}0.000894 \\
(0.026)\end{array}$ \\
\hline Sale food produced at home & 0.061 & $\begin{array}{c}-0.00864 \\
(0.021)\end{array}$ & 0.057 & $\begin{array}{r}-0.0169^{*} \\
(0.0093)\end{array}$ \\
\hline Sale manuf. produced at home & 0.013 & $\begin{array}{l}0.00904 \\
(0.0063)\end{array}$ & 0.013 & $\begin{array}{l}0.0174^{*} \\
(0.0086)\end{array}$ \\
\hline Sale products no produced at home & 0.051 & $\begin{array}{l}0.0143 \\
(0.021)\end{array}$ & 0.058 & $\begin{array}{c}0.00526 \\
(0.012)\end{array}$ \\
\hline Services self-employed & 0.034 & $\begin{array}{r}-0.00550 \\
(0.0097)\end{array}$ & 0.025 & $\begin{array}{c}-0.00818^{*} \\
(0.0041)\end{array}$ \\
\hline No skill wage-employed & 0.075 & $\begin{array}{l}0.0168 \\
(0.017)\end{array}$ & 0.071 & $\begin{array}{l}0.00955 \\
(0.0075)\end{array}$ \\
\hline Skill wage-employed & 0.025 & $\begin{array}{c}-0.00164 \\
(0.0094)\end{array}$ & 0.020 & $\begin{array}{c}0.00433 \\
(0.0043)\end{array}$ \\
\hline Obs. & & 484 & & 1877 \\
\hline
\end{tabular}

$\dagger$ Drought dummy taking value equal to one if rainfall is equal or less than the historical grid mean minus one standard deviation.

All regressions include household level controls, regional fixed effects, location controls and treatment controls. Robust Standard errors, in parentheses, are clustered by comarca. ${ }^{*} \mathrm{p}<0.1,{ }^{* *} \mathrm{p}<0.05,{ }^{* * *} \mathrm{p}<0.01$

Households receiving remittances from migrants between 15 and 30 years old in 2010 living in other communities 


\section{A Appendix: Descriptive Statistics Migrants}

Table A1: Respondents rates: Cohort 15-21 years old in 2010 .

\begin{tabular}{lcccccccc} 
& \multicolumn{2}{c}{ Females } & & \multicolumn{2}{c}{ Males } & & \multicolumn{2}{c}{ Total } \\
\cline { 2 - 3 } & No. & $\%$ & & No. & $\%$ & & No. & $\%$ \\
\hline Surveyed & 1,686 & 86.6 & & 1,855 & 90.5 & & 3,541 & 88.6 \\
Not surveyed & 262 & 13.4 & & 195 & 9.5 & & 457 & 11.4 \\
\hline Total & 1,948 & & 2,050 & & 3,998 & \\
\hline
\end{tabular}

Table A2: Surveyed Migrant Status: Cohort 15-21 years old in 2010 found and surveyed

\begin{tabular}{|c|c|c|c|c|c|c|}
\hline & \multicolumn{2}{|c|}{ Females } & \multicolumn{2}{|c|}{ Males } & \multicolumn{2}{|c|}{ Total } \\
\hline & No. & $\%$ & No. & $\%$ & No. & $\%$ \\
\hline No migrants & 831 & 49.2 & 1,304 & 70.3 & 2,133 & 60.2 \\
\hline Individual Migrants & 666 & 39.6 & 287 & 15.5 & 955 & 27.0 \\
\hline Household Migration & 189 & 11.2 & 264 & 14.2 & 453 & 12.8 \\
\hline Total & 1,686 & & 1,855 & & 3,541 & \\
\hline
\end{tabular}

Notes: Household migration includes migrants who moved with the caregiver of children in 2000. Local migrants are defined as those sharing weather shocks with the household of origin.

Table A3: Not Surveyed Sample: Cohort 15-21 years old in 2010

\begin{tabular}{|c|c|c|c|c|c|c|}
\hline & \multicolumn{2}{|c|}{ Females } & \multicolumn{2}{|c|}{ Males } & \multicolumn{2}{|c|}{ Total } \\
\hline & No. & $\%$ & No. & $\%$ & No. & $\%$ \\
\hline \multicolumn{7}{|c|}{ Migrant status: No Respondents } \\
\hline Individual Migrants & 151 & 57.6 & 90 & 46.2 & 241 & 52.7 \\
\hline Household Migration & 51 & 19.5 & 40 & 20.5 & 91 & 19.9 \\
\hline Untraceable & 58 & 22.1 & 64 & 32.8 & 122 & 26.7 \\
\hline Refused & 2 & 0.8 & 1 & 0.5 & 3 & 0.7 \\
\hline Total & 262 & & 195 & & 457 & \\
\hline
\end{tabular}

Notes: Untraceable implies that there is no information on the final location. 
Table A4: Baseline Characteristics-2000 by destination. Cohort 15-21 years old in 2010.

\begin{tabular}{|c|c|c|c|c|c|}
\hline & \multirow[b]{2}{*}{$\begin{array}{c}\text { Complete } \\
\text { Sample }\end{array}$} & \multirow[b]{2}{*}{$\begin{array}{c}\text { Local } \\
\text { Migrants } \\
\end{array}$} & \multirow[b]{2}{*}{$\begin{array}{c}\text { Non-Local } \\
\text { Migrants }\end{array}$} & \multicolumn{2}{|c|}{ Non-Local Migrants } \\
\hline & & & & $\begin{array}{c}\text { Rural } \\
\text { Migrants } \\
\end{array}$ & $\begin{array}{c}\text { Urban } \\
\text { Migrants }\end{array}$ \\
\hline Phase I $R P S$ & 0.51 & $\begin{array}{c}0.04 \\
(0.03)\end{array}$ & $\begin{array}{l}-0.01 \\
(0.03)\end{array}$ & $\begin{array}{c}0.05 \\
(0.04)\end{array}$ & $\begin{array}{l}-0.10 \\
(0.08)\end{array}$ \\
\hline \multicolumn{6}{|l|}{ Individual Characteristics in 2000} \\
\hline Female & 0.48 & $\begin{array}{c}0.25^{* * *} \\
(0.03)\end{array}$ & $\begin{array}{c}0.31^{* * *} \\
(0.03)\end{array}$ & $\begin{array}{c}0.32^{* * * *} \\
(0.03)\end{array}$ & $\begin{array}{c}0.25^{* * *} \\
(0.04)\end{array}$ \\
\hline Years of education & 0.79 & $\begin{array}{c}0.11^{*} \\
(0.06)\end{array}$ & $\begin{array}{c}0.37^{* * *} \\
(0.09)\end{array}$ & $\begin{array}{c}0.09 \\
(0.09)\end{array}$ & $\begin{array}{c}0.73^{* * *} \\
(0.12)\end{array}$ \\
\hline Work last week & 0.08 & $\begin{array}{c}-0.03^{* *} \\
(0.01)\end{array}$ & $\begin{array}{l}-0.01 \\
(0.01)\end{array}$ & $\begin{array}{l}-0.01 \\
(0.02)\end{array}$ & $\begin{array}{l}-0.01 \\
(0.02)\end{array}$ \\
\hline Child of the hh head & 0.83 & $\begin{array}{c}-0.20 * * * \\
(0.03)\end{array}$ & $\begin{array}{c}-0.15^{* * *} \\
(0.03)\end{array}$ & $\begin{array}{c}-0.16^{* * *} \\
(0.03)\end{array}$ & $\begin{array}{c}-0.12^{* *} \\
(0.05)\end{array}$ \\
\hline \multicolumn{6}{|l|}{ Household head Characteristics in 2000} \\
\hline Female & 0.11 & $\begin{array}{c}0.03 \\
(0.02)\end{array}$ & $\begin{array}{c}0.02 \\
(0.03)\end{array}$ & $\begin{array}{l}-0.01 \\
(0.02)\end{array}$ & $\begin{array}{c}0.07 \\
(0.05)\end{array}$ \\
\hline Age & 44.16 & $\begin{array}{c}3.80^{* * *} \\
(0.72)\end{array}$ & $\begin{array}{c}2.61^{* * *} \\
(0.72)\end{array}$ & $\begin{array}{l}2.00^{* * *} \\
(0.88)\end{array}$ & $\begin{array}{l}3.15^{* *} \\
(1.19)\end{array}$ \\
\hline Years of education & 1.56 & $\begin{array}{c}-0.35^{* * *} \\
(0.11)\end{array}$ & $\begin{array}{l}-0.10 \\
(0.12)\end{array}$ & $\begin{array}{l}-0.08 \\
(0.16)\end{array}$ & $\begin{array}{l}-0.12 \\
(0.18)\end{array}$ \\
\hline Agriculture activity & 0.88 & $\begin{array}{c}0.01 \\
(0.01)\end{array}$ & $\begin{array}{c}0.01 \\
(0.02)\end{array}$ & $\begin{array}{c}0.03 \\
(0.02)\end{array}$ & $\begin{array}{l}-0.01 \\
(0.03)\end{array}$ \\
\hline \multicolumn{6}{|l|}{ Household Characteristics } \\
\hline House ownership & 0.85 & $\begin{array}{l}-0.03 \\
(0.02)\end{array}$ & $\begin{array}{c}0.01 \\
(0.02)\end{array}$ & $\begin{array}{l}-0.03 \\
(0.03)\end{array}$ & $\begin{array}{l}0.07^{*} \\
(0.04)\end{array}$ \\
\hline Land ownership & 0.86 & $\begin{array}{l}-0.02 \\
(0.02)\end{array}$ & $\begin{array}{c}0.05^{* *} \\
(0.02)\end{array}$ & $\begin{array}{c}0.01 \\
(0.03)\end{array}$ & $\begin{array}{c}0.09^{* * *} \\
(0.03)\end{array}$ \\
\hline Livestock & 0.16 & $\begin{array}{l}-0.02 \\
(0.02)\end{array}$ & $\begin{array}{c}0.04 \\
(0.02)\end{array}$ & $\begin{array}{l}-0.02 \\
(0.03)\end{array}$ & $\begin{array}{c}0.12^{* *} \\
(0.05)\end{array}$ \\
\hline Log Total Consumption p.c & 7.72 & $\begin{array}{c}-0.08^{* * * *} \\
(0.02)\end{array}$ & $\begin{array}{c}0.01 \\
(0.02)\end{array}$ & $\begin{array}{l}-0.01 \\
(0.03)\end{array}$ & $\begin{array}{c}0.03 \\
(0.03)\end{array}$ \\
\hline Extreme poverty & 0.54 & $\begin{array}{c}0.09 * * * \\
(0.03)\end{array}$ & $\begin{array}{c}0.01 \\
(0.03)\end{array}$ & $\begin{array}{c}0.00 \\
(0.04)\end{array}$ & $\begin{array}{c}0.01 \\
(0.05)\end{array}$ \\
\hline Distance school (min) & 25.58 & $\begin{array}{c}1.44 \\
(1.87)\end{array}$ & $\begin{array}{l}-0.29 \\
(1.47)\end{array}$ & $\begin{array}{c}3.61 \\
(2.62)\end{array}$ & $\begin{array}{c}-6.12^{* *} \\
(2.83)\end{array}$ \\
\hline Vegetation index & 0.88 & $\begin{array}{c}0.00 \\
(0.00)\end{array}$ & $\begin{array}{l}-0.00 \\
(0.00)\end{array}$ & $\begin{array}{c}0.02^{* * *} \\
(0.00)\end{array}$ & $\begin{array}{c}-0.03^{* * *} \\
(0.01)\end{array}$ \\
\hline \multicolumn{6}{|l|}{ Household Composition in 2000} \\
\hline Household members: ages $0-4$ yrs old & 1.10 & $\begin{array}{c}0.16^{* * * *} \\
(0.05)\end{array}$ & $\begin{array}{l}-0.06 \\
(0.05)\end{array}$ & $\begin{array}{l}-0.00 \\
(0.07)\end{array}$ & $\begin{array}{c}-0.13^{* *} \\
(0.06)\end{array}$ \\
\hline Household members: ages $5-15$ yrs old & 3.56 & $\begin{array}{c}0.18^{* *} \\
(0.07)\end{array}$ & $\begin{array}{c}0.08 \\
(0.07)\end{array}$ & $\begin{array}{c}0.08 \\
(0.09)\end{array}$ & $\begin{array}{c}0.08 \\
(0.15)\end{array}$ \\
\hline Household members: ages $16-30$ yrs old & 1.73 & $\begin{array}{l}0.18^{*} \\
(0.09)\end{array}$ & $\begin{array}{c}0.34^{* * *} \\
(0.11)\end{array}$ & $\begin{array}{l}0.25^{* *} \\
(0.11)\end{array}$ & $\begin{array}{l}0.43^{* *} \\
(0.18)\end{array}$ \\
\hline Household members: ages $31-60$ yrs old & 1.62 & $\begin{array}{c}0.14^{* *} \\
(0.07)\end{array}$ & $\begin{array}{c}0.04 \\
(0.04)\end{array}$ & $\begin{array}{c}0.01 \\
(0.06)\end{array}$ & $\begin{array}{c}0.09 \\
(0.07)\end{array}$ \\
\hline Household members: ages over 61 yrs old & 0.19 & $\begin{array}{c}0.11^{* * *} \\
(0.03)\end{array}$ & $\begin{array}{l}0.07^{*} \\
(0.04)\end{array}$ & $\begin{array}{l}0.10^{*} \\
(0.06)\end{array}$ & $\begin{array}{c}0.01 \\
(0.05)\end{array}$ \\
\hline
\end{tabular}

Robust Standard errors, in parentheses, are clustered by comarca. ${ }^{*} \mathrm{p}<0.1,{ }^{* *} \mathrm{p}<0.05,{ }^{* * *} \mathrm{p}<0.01$

Column 1 presents the average value for the complete sample, while Columns 2-4 report the differences in means (standard errors in parentheses) by destination with respect to the rest of the sample (including those who did not move). 
Table A5: Motives behind the decision to migrate by destination. Reported by a member of the origin household. Cohort 15-21 years old in 2010.

\begin{tabular}{|c|c|c|c|c|c|c|c|c|}
\hline & \multirow{2}{*}{\multicolumn{2}{|c|}{$\begin{array}{c}\text { Local } \\
\text { Migrants }\end{array}$}} & \multirow{2}{*}{\multicolumn{2}{|c|}{$\begin{array}{c}\text { Non-Local } \\
\text { Migrants }\end{array}$}} & \multicolumn{4}{|c|}{ Non-Local Migrants } \\
\hline & & & & & \multicolumn{2}{|c|}{$\begin{array}{c}\text { Rural } \\
\text { Migrants }\end{array}$} & \multicolumn{2}{|c|}{$\begin{array}{c}\text { Urban } \\
\text { Migrants }\end{array}$} \\
\hline & No. & $\%$ & No. & $\%$ & No. & $\%$ & No. & $\%$ \\
\hline Work & 9 & 1.9 & 55 & 15.1 & 12 & 5.3 & 43 & 31.4 \\
\hline Taken & 95 & 20 & 50 & 13.7 & 32 & 14 & 18 & 13.1 \\
\hline Change civil stat & 303 & 63.8 & 168 & 46 & 142 & 62.3 & 26 & 19 \\
\hline Study & 1 & 0.2 & 41 & 11.2 & 12 & 5.3 & 29 & 21.2 \\
\hline Better econ. situation & 22 & 4.6 & 37 & 10.1 & 21 & 9.2 & 16 & 11.7 \\
\hline Emancipate & 37 & 7.8 & 10 & 2.7 & 6 & 2.6 & 4 & 2.9 \\
\hline Other & 8 & 1.7 & 4 & 1.1 & 3 & 1.3 & 1 & 0.7 \\
\hline
\end{tabular}




\section{B Appendix: Robustness Checks}

Table B1: OLS: Impact of Weather Shocks on Remittances and Transfers Receipts. Urban Migrants (15-21 years old). Including rainfall shocks at destination.

\begin{tabular}{|c|c|c|c|c|c|}
\hline & \multicolumn{2}{|c|}{ Probability } & \multicolumn{3}{|c|}{ Total Annual Value (USD) } \\
\hline & $\begin{array}{l}\text { Receive } \\
\text { Transfers }\end{array}$ & Remit & Transfers & Remittances & $\begin{array}{c}\text { Net } \\
\text { Transfers }\end{array}$ \\
\hline Negative Rainfall SD: origin & $\begin{array}{c}-0.17^{* *} \\
(0.06)\end{array}$ & $\begin{array}{l}-0.03 \\
(0.06)\end{array}$ & $\begin{array}{c}-19.73^{* *} \\
(8.39)\end{array}$ & $\begin{array}{l}15.60^{*} \\
(7.81)\end{array}$ & $\begin{array}{c}-36.05^{* *} \\
(13.29)\end{array}$ \\
\hline Negative Rainfall SD: destination & $\begin{array}{c}0.06 \\
(0.15)\end{array}$ & $\begin{array}{c}0.10 \\
(0.20)\end{array}$ & $\begin{array}{c}7.78 \\
(16.46)\end{array}$ & $\begin{array}{c}-2.76 \\
(27.55)\end{array}$ & $\begin{array}{c}10.44 \\
(35.76)\end{array}$ \\
\hline Outcome mean & 0.36 & 0.39 & 19.58 & 36.56 & -16.49 \\
\hline Mean shock origin & 0.67 & 0.67 & 0.67 & 0.67 & 0.67 \\
\hline Mean shock destination & 0.50 & 0.50 & 0.50 & 0.50 & 0.50 \\
\hline Obs & 141 & 138 & 140 & 138 & 137 \\
\hline $\mathrm{P}$-value: $\beta_{o}+\beta_{d}=0$ & 0.532 & 0.742 & 0.384 & 0.603 & 0.368 \\
\hline
\end{tabular}

Notes: Negative Rainfall SD accounts for deviations of accumulated rain between June-July in 2009 from the historical mean divided by the standard deviation for each node multiplied by minus one. Positive values represent rainfall deficits with respect to the historical mean.

All regressions include household and individual level controls, regional fixed effects at origin and at destination, location controls and treatment controls.Dependent values inputed max and min values for the $1 \%$ highest and lowest outliers. Robust Standard errors, in parentheses, are clustered by comarca. ${ }^{*} \mathrm{p}<0.1$, $* * \mathrm{p}<0.05,{ }^{* * *} \mathrm{p}<0.01$ 
Figure 7: Rural Migrants (15-21 years old). Impact of Negative Rainfall SD at origin on the Net Value of Transfers $\left(\beta_{N T r}^{o}\right)$

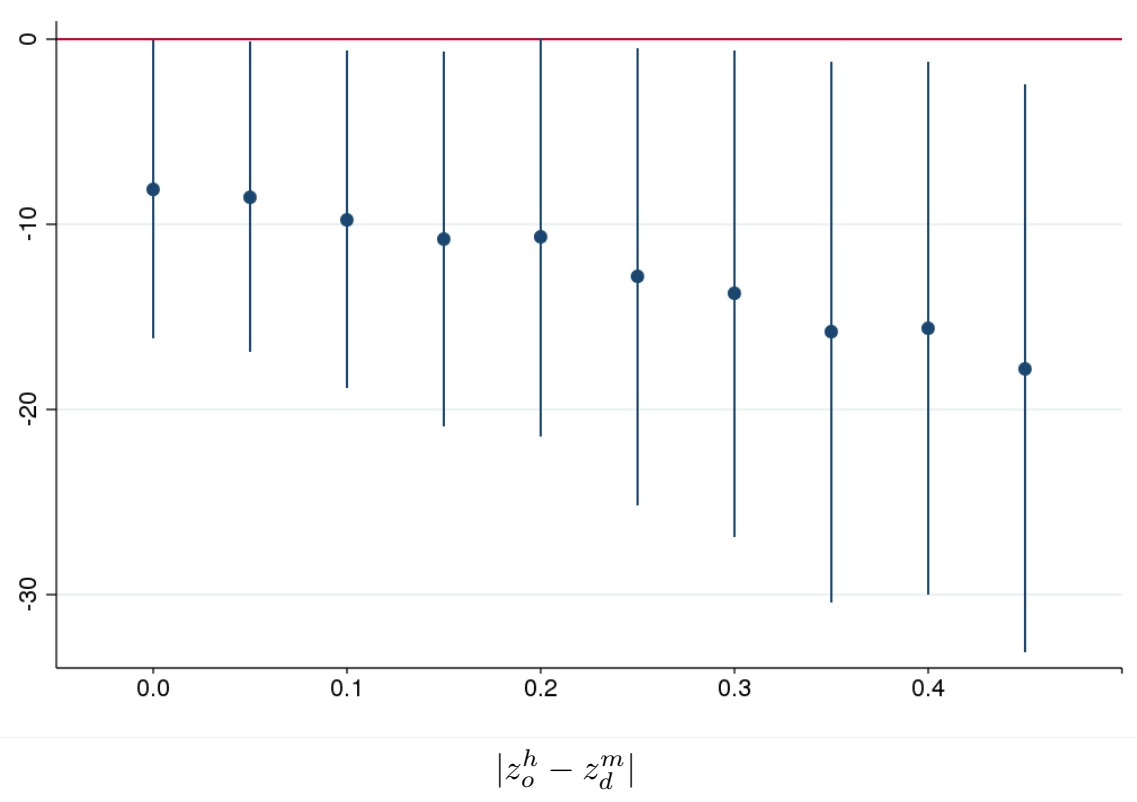

Figure 8: Rural Migrants (15-21 years old). Impact of Negative Rainfall SD at destination on the Net Value of Transfers $\left(\beta_{N T r}^{d}\right)$

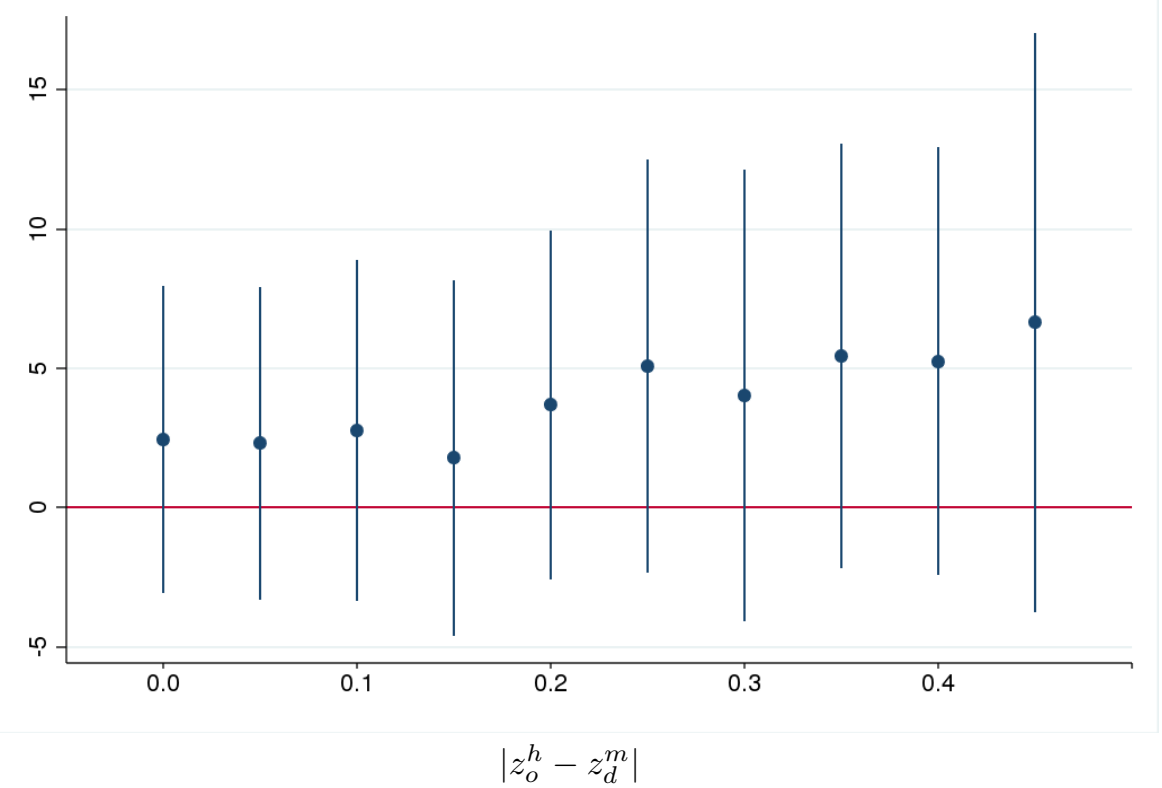

Notes (Figures $5 \&$ 6): Each figure plots coefficient estimates ( $\beta_{T r}^{d}$ and $\beta_{R}^{o}$ respectively) of running Equation 14 and 15 on the pool of migrants satisfying $\left|z_{o}^{h}-z_{d}^{m}\right|>x$, where $\mathrm{x}$ takes values from 0 to 0.45 in 0.05 intervals. Negative Rainfall SD accounts for deviations of accumulated rain between June-July in 2009 from the historical mean divided by the standard deviation for each node multiplied by minus one. Positive values represent rainfall deficits with respect to the historical mean. Confidence Intervals are set at 90\%. All regressions include household and individual level controls, regional fixed effects at origin and at destination, location controls and treatment controls.Dependent values inputed $\max$ and min values for the $1 \%$ highest and lowest outliers. Robust Standard errors, in parentheses, are clustered by comarca. 
Table B2: OLS: Impact of Weather Shocks on Remittances and Transfers Receipts. Non-Local Migrants Whom Origin Household Head Works Only In Agriculture (1521 years old)

\begin{tabular}{|c|c|c|c|c|c|}
\hline & \multicolumn{2}{|c|}{ Probability } & \multicolumn{3}{|c|}{ Total Annual Value (USD) } \\
\hline & $\begin{array}{l}\text { Receive } \\
\text { Transfers }\end{array}$ & Remit & Transfers & Remittances & $\begin{array}{c}\text { Net } \\
\text { Transfers }\end{array}$ \\
\hline Negative Rainfall SD: origin & $\begin{array}{l}-0.00 \\
(0.08)\end{array}$ & $\begin{array}{c}0.05 \\
(0.05)\end{array}$ & $\begin{array}{c}-10.00^{* *} \\
(4.46)\end{array}$ & $\begin{array}{l}-3.81 \\
(5.45)\end{array}$ & $\begin{array}{l}-6.21 \\
(8.21)\end{array}$ \\
\hline Head orig agric*Shock origin & $\begin{array}{l}-0.06 \\
(0.11)\end{array}$ & $\begin{array}{c}0.00 \\
(0.07)\end{array}$ & $\begin{array}{c}2.31 \\
(5.41)\end{array}$ & $\begin{array}{l}19.21^{*} \\
(10.44)\end{array}$ & $\begin{array}{c}-17.49 \\
(13.18)\end{array}$ \\
\hline Negative Rainfall SD: destination & $\begin{array}{l}-0.05 \\
(0.12)\end{array}$ & $\begin{array}{c}-0.15^{* * *} \\
(0.04)\end{array}$ & $\begin{array}{c}4.80 \\
(9.08)\end{array}$ & $\begin{array}{l}-6.56 \\
(5.24)\end{array}$ & $\begin{array}{l}10.89 \\
(8.89)\end{array}$ \\
\hline Head orig agric*Shock destination & $\begin{array}{c}0.11 \\
(0.16)\end{array}$ & $\begin{array}{l}0.14^{*} \\
(0.08)\end{array}$ & $\begin{array}{l}-3.88 \\
(9.71)\end{array}$ & $\begin{array}{c}0.85 \\
(6.77)\end{array}$ & $\begin{array}{c}-4.65 \\
(10.88)\end{array}$ \\
\hline Head orig agriculure & $\begin{array}{l}0.15^{*} \\
(0.08)\end{array}$ & $\begin{array}{c}0.17^{* * *} \\
(0.05)\end{array}$ & $\begin{array}{c}8.97 \\
(5.60)\end{array}$ & $\begin{array}{l}-4.44 \\
(6.12)\end{array}$ & $\begin{array}{l}14.64 \\
(9.42)\end{array}$ \\
\hline Outcome mean & 0.35 & 0.34 & 12.33 & 18.66 & -5.96 \\
\hline Mean interaction & 0.80 & 0.80 & 0.80 & 0.80 & 0.80 \\
\hline Mean shock origin & 0.36 & 0.36 & 0.36 & 0.36 & 0.36 \\
\hline Mean shock destination & 0.13 & 0.13 & 0.13 & 0.13 & 0.13 \\
\hline Obs & 357 & 348 & 355 & 347 & 346 \\
\hline Pvalue: shock orig & 0.628 & 0.442 & 0.011 & 0.118 & 0.034 \\
\hline Pvalue: shock dest & 0.643 & 0.004 & 0.850 & 0.342 & 0.349 \\
\hline
\end{tabular}

Notes: Negative Rainfall SD accounts for deviations of accumulated rain between June-July in 2009 from the historical mean divided by the standard deviation for each node multiplied by minus one. Positive values represent rainfall deficits with respect to the historical mean.

All regressions include household and individual level controls, regional fixed effects at origin and at destination, location controls and treatment controls.Dependent values inputed max and min values for the $1 \%$ highest and lowest outliers. Robust Standard errors, in parentheses, are clustered by comarca. ${ }^{*} \mathrm{p}<0.1$, $* * \mathrm{p}<0.05,{ }^{* * *} \mathrm{p}<0.01$

Table B3: OLS: Impact of Weather Shocks on Remittances and Transfers Receipts. Non-Local Migrants (15-21 years old).Non-Linear Rainfall Shocks

\begin{tabular}{lccccccc}
\hline & \multicolumn{2}{c}{ Probability to } & & \multicolumn{2}{c}{ Total Annual Value (USD) } \\
\cline { 2 - 3 } \cline { 6 - 7 } & $\begin{array}{c}\text { Receive } \\
\text { Transfers }\end{array}$ & Remit & & Transfers & Remittances & $\begin{array}{c}\text { Net } \\
\text { Transfers }\end{array}$ \\
\hline Drought origin & -0.09 & 0.10 & & $-14.12^{* * *}$ & & 13.98 & $-28.62^{* *}$ \\
& $(0.09)$ & $(0.09)$ & & $(4.27)$ & & $(9.72)$ & $(12.53)$ \\
Drought destination & 0.09 & -0.08 & & 2.07 & & -13.64 & 14.96 \\
& $(0.08)$ & $(0.08)$ & & $(6.07)$ & & $(8.93)$ & $(10.03)$ \\
Outcome mean & 0.35 & 0.34 & & 12.33 & & 18.66 & -5.96 \\
Mean shock origin & 0.17 & 0.17 & & 0.17 & & 0.17 & 0.17 \\
Mean shock destination & 0.10 & 0.10 & & 0.10 & & 0.10 & 0.10 \\
Obs & 367 & 358 & & 365 & 357 & 356 \\
P-value: $\beta_{o}+\beta_{d}=0$ & 0.962 & 0.856 & & 0.124 & 0.962 & 0.177 \\
\hline
\end{tabular}

Drought dummy taking value equal to one if rainfall is equal or less than the historical grid mean minus one standard deviation.

All regressions include household and individual level controls, regional fixed effects at origin and at destination, location controls and treatment controls.Dependent values inputed max and min values for the $1 \%$ highest and lowest outliers. Robust Standard errors, in parentheses, are clustered by comarca. ${ }^{*} \mathrm{p}<0.1,{ }^{* *} \mathrm{p}<0.05,{ }^{* * *} \mathrm{p}<0.01$ 
Table B4: OLS: Impact of Weather Shocks on Remittances and Transfers Receipts. Non-Local Migrants by Destination (15-21 years old). Non-Linear Rainfall Shocks

\begin{tabular}{|c|c|c|c|c|c|}
\hline & \multicolumn{2}{|c|}{ Probability to } & \multicolumn{3}{|c|}{ Total Annual Value (USD) } \\
\hline & $\begin{array}{c}\text { Receive } \\
\text { Transfers }\end{array}$ & Remit & Transfers & Remittances & $\begin{array}{c}\text { Net } \\
\text { Transfers }\end{array}$ \\
\hline & \multicolumn{5}{|c|}{ Rural Non-Local Migrants } \\
\hline Drought origin & $\begin{array}{l}-0.03 \\
(0.14)\end{array}$ & $\begin{array}{c}0.16 \\
(0.13)\end{array}$ & $\begin{array}{l}-9.19 \\
(6.69)\end{array}$ & $\begin{array}{l}6.74^{*} \\
(3.87)\end{array}$ & $\begin{array}{c}-16.78^{* *} \\
(8.27)\end{array}$ \\
\hline Drought destination & $\begin{array}{c}0.12 \\
(0.11)\end{array}$ & $\begin{array}{l}-0.09 \\
(0.10)\end{array}$ & $\begin{array}{c}2.38 \\
(5.36)\end{array}$ & $\begin{array}{l}-4.57 \\
(3.56)\end{array}$ & $\begin{array}{l}7.08 \\
(5.74)\end{array}$ \\
\hline Outcome mean & 0.34 & 0.31 & 7.79 & 7.32 & 0.66 \\
\hline Mean shock origin & 0.14 & 0.14 & 0.14 & 0.14 & 0.14 \\
\hline Mean shock destination & 0.16 & 0.16 & 0.16 & 0.16 & 0.16 \\
\hline Obs & 225 & 219 & 224 & 218 & 218 \\
\hline \multirow[t]{2}{*}{ P-value: $\beta_{o}+\beta_{d}=0$} & 0.445 & 0.513 & 0.343 & 0.455 & 0.171 \\
\hline & \multicolumn{5}{|c|}{ Urban Non-Local Migrants } \\
\hline Drought origin & $\begin{array}{c}-0.26^{* *} \\
(0.11)\end{array}$ & $\begin{array}{c}0.06 \\
(0.10)\end{array}$ & $\begin{array}{c}-27.50^{* *} \\
(11.13)\end{array}$ & $\begin{array}{l}27.45^{*} \\
(14.53)\end{array}$ & $\begin{array}{c}-56.31^{* *} \\
(20.72)\end{array}$ \\
\hline Outcome mean & 0.36 & 0.39 & 19.58 & 36.56 & -16.49 \\
\hline Mean shock origin & 0.23 & 0.23 & 0.23 & 0.23 & 0.23 \\
\hline Obs & 142 & 139 & 141 & 139 & 138 \\
\hline
\end{tabular}

Drought dummy taking value equal to one if rainfall is equal or less than the historical grid mean minus one standard deviation.

All regressions include household and individual level controls, regional fixed effects at origin and at destination, location controls and treatment controls. Dependent values inputed max and min values for the $1 \%$ highest and lowest outliers. Robust Standard errors, in parentheses, are clustered by comarca. ${ }^{*} \mathrm{p}<0.1,{ }^{* *} \mathrm{p}<0.05,{ }^{* * *} \mathrm{p}<0.01$ 
Table B5: OLS: Impact of Weather Shocks on Remittances and Transfers Receipts. Non-Local Migrants by Economic Activity (15-21 years old). NonLinear Rainfall Shocks

\begin{tabular}{|c|c|c|c|c|c|}
\hline & \multicolumn{2}{|c|}{ Probability to } & \multicolumn{3}{|c|}{ Total Annual Value (USD) } \\
\hline & $\begin{array}{c}\text { Receive } \\
\text { Transfers }\end{array}$ & Remit & Transfers & Remittances & $\begin{array}{c}\text { Net } \\
\text { Transfers }\end{array}$ \\
\hline & \multicolumn{5}{|c|}{ Only Agricultural Activities } \\
\hline Drought origin & $\begin{array}{c}0.04 \\
(0.14)\end{array}$ & $\begin{array}{c}0.15 \\
(0.15)\end{array}$ & $\begin{array}{c}-14.97^{*} \\
(8.56)\end{array}$ & $\begin{array}{c}5.25 \\
(5.37)\end{array}$ & $\begin{array}{c}-19.50^{*} \\
(9.86)\end{array}$ \\
\hline Drought destination & $\begin{array}{l}-0.04 \\
(0.11)\end{array}$ & $\begin{array}{l}-0.11 \\
(0.11)\end{array}$ & $\begin{array}{l}-7.03 \\
(5.60)\end{array}$ & $\begin{array}{l}-9.87^{*} \\
(5.41)\end{array}$ & $\begin{array}{c}2.76 \\
(7.29)\end{array}$ \\
\hline Outcome mean & 0.33 & 0.34 & 9.04 & 9.77 & -0.45 \\
\hline Mean shock origin & 0.17 & 0.17 & 0.17 & 0.17 & 0.17 \\
\hline Mean shock destination & 0.17 & 0.17 & 0.17 & 0.17 & 0.17 \\
\hline Obs & 166 & 161 & 165 & 160 & 160 \\
\hline \multirow{2}{*}{ P-value: $\beta_{o}+\beta_{d}=0$} & 0.978 & 0.813 & 0.045 & 0.390 & 0.133 \\
\hline & \multicolumn{5}{|c|}{ Agricultural and Non-Agricultural Activities } \\
\hline Drought origin & $\begin{array}{l}-0.21 \\
(0.13)\end{array}$ & $\begin{array}{c}0.09 \\
(0.13)\end{array}$ & $\begin{array}{c}-24.02^{* *} \\
(11.73)\end{array}$ & $\begin{array}{l}37.90^{*} \\
(19.67)\end{array}$ & $\begin{array}{c}-62.37^{* *} \\
(26.23)\end{array}$ \\
\hline Drought destination & $\begin{array}{c}0.08 \\
(0.19)\end{array}$ & $\begin{array}{c}0.13 \\
(0.18)\end{array}$ & $\begin{array}{l}-0.98 \\
(8.24)\end{array}$ & $\begin{array}{c}-22.63 \\
(19.43)\end{array}$ & $\begin{array}{c}23.57 \\
(23.05)\end{array}$ \\
\hline Outcome mean & 0.35 & 0.40 & 12.31 & 32.66 & -20.15 \\
\hline Mean shock origin & 0.19 & 0.19 & 0.19 & 0.19 & 0.19 \\
\hline Mean shock destination & 0.14 & 0.14 & 0.14 & 0.14 & 0.14 \\
\hline Obs & 141 & 140 & 140 & 140 & 139 \\
\hline P-value: $\beta_{o}+\beta_{d}=0$ & 0.479 & 0.306 & 0.078 & 0.478 & 0.146 \\
\hline
\end{tabular}

Drought dummy taking value equal to one if rainfall is equal or less than the historical grid mean minus one standard deviation.

All regressions include household and individual level controls, regional fixed effects at origin and at destination, location controls and treatment controls.Dependent values inputed max and min values for the $1 \%$ highest and lowest outliers. Robust Standard errors, in parentheses, are clustered by comarca. ${ }^{*} \mathrm{p}<0.1,{ }^{*} \mathrm{p}<0.05, * * * \mathrm{p}<0.01$

Table B6: OLS: Impact of Weather Shocks on Remittances and Transfers Receipts. Non-Local Migrants Whom the Head of Household of Origin Works Only on the Agricultural Sector. Non-Linear Rainfall Shocks

\begin{tabular}{lccccccc}
\hline & \multicolumn{2}{c}{ Probability } & & \multicolumn{2}{c}{ Total Annual Value (USD) } \\
\cline { 2 - 3 } & $\begin{array}{c}\text { Receive } \\
\text { Transfers }\end{array}$ & Remit & & Transfers & Remittances & $\begin{array}{c}\text { Net } \\
\text { Transfers }\end{array}$ \\
\hline Drought origin & -0.06 & $0.19^{*}$ & & $-16.25^{* *}$ & $27.63^{* *}$ & $-44.68^{* *}$ \\
& $(0.12)$ & $(0.10)$ & & $(6.42)$ & & $(13.56)$ & $(17.84)$ \\
Drought destination & $0.18^{*}$ & -0.04 & & 3.62 & & -10.16 & 12.83 \\
& $(0.10)$ & $(0.10)$ & & $(6.95)$ & & $(9.79)$ & $(11.94)$ \\
Outcome mean & 0.37 & 0.36 & & 13.31 & & 18.01 & -4.24 \\
Mean shock origin & 0.15 & 0.15 & & 0.15 & & 0.15 & 0.15 \\
Mean shock destination & 0.10 & 0.10 & & 0.10 & & 0.10 & 0.10 \\
Obs & 298 & 290 & & 296 & & 289 & 288 \\
P-value: $\beta_{o}+\beta_{d}=0$ & 0.376 & 0.258 & & 0.116 & 0.050 & 0.029 \\
\hline
\end{tabular}

Drought dummy taking value equal to one if rainfall is equal or less than the historical grid mean minus one standard deviation.

All regressions include household and individual level controls, regional fixed effects at origin and at destination, location controls and treatment controls.Dependent values inputed max and min values for the $1 \%$ highest and lowest outliers. Robust Standard errors, in parentheses, are clustered by comarca. ${ }^{*} \mathrm{p}<0.1,{ }^{*} \mathrm{p}<0.05, * * * \mathrm{p}<0.01$ 
Table B7: OLS: Impact of Weather Shocks on Remittances and Transfers Receipts. NonLocal Migrants (15-21 years old)

\begin{tabular}{|c|c|c|c|c|c|}
\hline & \multicolumn{3}{|c|}{ Log (hyperbolic transformation) } & \multicolumn{2}{|c|}{ Square Root } \\
\hline & Transfers & Remittances & $\begin{array}{c}\text { Net } \\
\text { Transfers }\end{array}$ & Transfers & Remittances \\
\hline Negative Rainfall SD: origin & $\begin{array}{l}-0.33 \\
(0.20)\end{array}$ & $\begin{array}{c}0.22 \\
(0.18)\end{array}$ & $\begin{array}{c}-0.54^{* *} \\
(0.26)\end{array}$ & $\begin{array}{c}-1.53^{* *} \\
(0.72)\end{array}$ & $\begin{array}{l}0.73^{*} \\
(0.37)\end{array}$ \\
\hline Negative Rainfall SD: destination & $\begin{array}{c}0.21 \\
(0.19)\end{array}$ & $\begin{array}{l}-0.32^{*} \\
(0.17)\end{array}$ & $\begin{array}{c}0.44 \\
(0.28)\end{array}$ & $\begin{array}{c}0.37 \\
(0.42)\end{array}$ & $\begin{array}{l}-0.67^{*} \\
(0.36)\end{array}$ \\
\hline Outcome mean & 1.21 & 1.34 & -0.27 & 2.00 & 2.17 \\
\hline Mean shock origin & 0.36 & 0.36 & 0.36 & 0.36 & 0.36 \\
\hline Mean shock destination & 0.13 & 0.13 & 0.13 & 0.13 & 0.13 \\
\hline Obs & 355 & 347 & 346 & 355 & 347 \\
\hline P-value: $\beta_{o}+\beta_{d}=0$ & 0.646 & 0.640 & 0.740 & 0.112 & 0.861 \\
\hline
\end{tabular}

Notes: Negative Rainfall SD accounts for deviations of accumulated rain between June-July in 2009 from the historical mean divided by the standard deviation for each node multiplied by minus one. Positive values represent rainfall deficits with respect to the historical mean.

All regressions include household and individual level controls, regional fixed effects at origin and at destination, location controls and treatment controls.Dependent values inputed max and min values for the $1 \%$ highest and lowest outliers. Robust Standard errors, in parentheses, are clustered by comarca. ${ }^{*} \mathrm{p}<0.1,{ }^{* *} \mathrm{p}<0.05,{ }^{* * *} \mathrm{p}<0.01$

Table B8: OLS: Impact of Weather Shocks on Remittances and Transfers Receipts. NonLocal Migrants by Destination (15-21 years old)

\begin{tabular}{|c|c|c|c|c|c|}
\hline & \multicolumn{3}{|c|}{ Log (hyperbolic transformation) } & \multicolumn{2}{|c|}{ Square Root } \\
\hline & Transfers & Remittances & $\begin{array}{c}\text { Net } \\
\text { Transfers }\end{array}$ & Transfers & Remittances \\
\hline & \multicolumn{5}{|c|}{ Rural Non-Local Migrants } \\
\hline Negative Rainfall SD: origin & $\begin{array}{l}-0.19 \\
(0.31)\end{array}$ & $\begin{array}{c}0.16 \\
(0.22)\end{array}$ & $\begin{array}{l}-0.42 \\
(0.35)\end{array}$ & $\begin{array}{l}-0.58 \\
(0.51)\end{array}$ & $\begin{array}{c}0.21 \\
(0.28)\end{array}$ \\
\hline Negative Rainfall SD: destination & $\begin{array}{c}0.17 \\
(0.21)\end{array}$ & $\begin{array}{l}-0.22 \\
(0.21)\end{array}$ & $\begin{array}{c}0.35 \\
(0.32)\end{array}$ & $\begin{array}{c}0.26 \\
(0.29)\end{array}$ & $\begin{array}{l}-0.27 \\
(0.29)\end{array}$ \\
\hline Outcome mean & 1.08 & 1.00 & -0.02 & 1.40 & 1.29 \\
\hline Mean shock origin & 0.17 & 0.17 & 0.17 & 0.17 & 0.17 \\
\hline Mean shock destination & 0.21 & 0.21 & 0.21 & 0.21 & 0.21 \\
\hline Obs & 214 & 208 & 208 & 214 & 208 \\
\hline \multirow[t]{2}{*}{ P-value: $\beta_{o}+\beta_{d}=0$} & 0.938 & 0.780 & 0.833 & 0.468 & 0.853 \\
\hline & \multicolumn{5}{|c|}{ Urban Non-Local Migrants } \\
\hline Negative Rainfall SD: origin & $\begin{array}{c}-0.82^{* *} \\
(0.30)\end{array}$ & $\begin{array}{c}0.07 \\
(0.22)\end{array}$ & $\begin{array}{c}-0.83^{* *} \\
(0.39)\end{array}$ & $\begin{array}{l}-4.72 \\
(3.30)\end{array}$ & $\begin{array}{l}0.85^{*} \\
(0.49)\end{array}$ \\
\hline Outcome mean & 1.40 & 1.89 & -0.66 & 2.96 & 3.56 \\
\hline Mean shock origin & 0.66 & 0.66 & 0.66 & 0.66 & 0.66 \\
\hline Obs & 141 & 139 & 138 & 141 & 139 \\
\hline
\end{tabular}

Notes: Negative Rainfall SD accounts for deviations of accumulated rain between June-July in 2009 from the historical mean divided by the standard deviation for each node multiplied by minus one. Positive values represent rainfall deficits with respect to the historical mean.

All regressions include household and individual level controls, regional fixed effects at origin and at destination, location controls and treatment controls.Dependent values inputed max and min values for the $1 \%$ highest and lowest outliers. Robust Standard errors, in parentheses, are clustered by comarca. ${ }^{*} \mathrm{p}<0.1,{ }^{* *} \mathrm{p}<0.05,{ }^{* * *} \mathrm{p}<0.01$ 
Table B9: OLS: Impact of Weather Shocks on Remittances and Transfers Receipts. NonLocal Migrants by Economic Activity (15-21 years old)

\begin{tabular}{|c|c|c|c|c|c|}
\hline & \multicolumn{3}{|c|}{ Log (hyperbolic transformation) } & \multicolumn{2}{|c|}{ Square Root } \\
\hline & Transfers & Remittances & $\begin{array}{c}\text { Net } \\
\text { Transfers }\end{array}$ & Transfers & Remittances \\
\hline & \multicolumn{5}{|c|}{ Only Agricultural Activities } \\
\hline Negative Rainfall SD: origin & $\begin{array}{l}-0.20 \\
(0.35)\end{array}$ & $\begin{array}{c}0.12 \\
(0.32)\end{array}$ & $\begin{array}{l}-0.42 \\
(0.39)\end{array}$ & $\begin{array}{l}-0.98 \\
(0.72)\end{array}$ & $\begin{array}{c}0.07 \\
(0.43)\end{array}$ \\
\hline Negative Rainfall SD: destination & $\begin{array}{l}-0.12 \\
(0.21)\end{array}$ & $\begin{array}{l}-0.23 \\
(0.23)\end{array}$ & $\begin{array}{c}0.00 \\
(0.28)\end{array}$ & $\begin{array}{l}-0.12 \\
(0.33)\end{array}$ & $\begin{array}{l}-0.28 \\
(0.31)\end{array}$ \\
\hline Outcome mean & 1.09 & 1.14 & -0.07 & 1.49 & 1.54 \\
\hline Mean shock origin & 0.28 & 0.28 & 0.28 & 0.28 & 0.28 \\
\hline Mean shock destination & 0.24 & 0.24 & 0.24 & 0.24 & 0.24 \\
\hline Obs & 156 & 151 & 151 & 156 & 151 \\
\hline \multirow[t]{2}{*}{ P-value: $\beta_{o}+\beta_{d}=0$} & 0.321 & 0.727 & 0.359 & 0.087 & 0.642 \\
\hline & \multicolumn{5}{|c|}{ Agricultural and Non-Agricultural Activities } \\
\hline Negative Rainfall SD: origin & $\begin{array}{l}-0.62 \\
(0.39)\end{array}$ & $\begin{array}{c}0.47 \\
(0.34)\end{array}$ & $\begin{array}{c}-0.97^{* *} \\
(0.42)\end{array}$ & $\begin{array}{c}-1.28^{*} \\
(0.68)\end{array}$ & $\begin{array}{l}1.60^{* *} \\
(0.66)\end{array}$ \\
\hline Negative Rainfall SD: destination & $\begin{array}{c}0.47 \\
(0.39)\end{array}$ & $\begin{array}{c}0.02 \\
(0.51)\end{array}$ & $\begin{array}{c}0.53 \\
(0.91)\end{array}$ & $\begin{array}{c}0.70 \\
(0.67)\end{array}$ & $\begin{array}{l}-0.89 \\
(1.04)\end{array}$ \\
\hline Outcome mean & 1.22 & 1.80 & -0.84 & 1.74 & 3.29 \\
\hline Mean shock origin & 0.46 & 0.46 & 0.46 & 0.46 & 0.46 \\
\hline Mean shock destination & 0.38 & 0.38 & 0.38 & 0.38 & 0.38 \\
\hline Obs & 138 & 138 & 137 & 138 & 138 \\
\hline P-value: $\beta_{o}+\beta_{d}=0$ & 0.758 & 0.422 & 0.614 & 0.492 & 0.551 \\
\hline
\end{tabular}

Notes: Negative Rainfall SD accounts for deviations of accumulated rain between June-July in 2009 from the historical mean divided by the standard deviation for each node multiplied by minus one. Positive values represent rainfall deficits with respect to the historical mean.

All regressions include household and individual level controls, regional fixed effects at origin and at destination, location controls and treatment controls.Dependent values inputed max and min values for the $1 \%$ highest and lowest outliers. Robust Standard errors, in parentheses, are clustered by comarca. ${ }^{*} \mathrm{p}<0.1,{ }^{* *} \mathrm{p}<0.05,{ }^{* * *} \mathrm{p}<0.01$

Table B10: OLS: Impact of Weather Shocks on Remittances and Transfers Receipts. NonLocal Migrants Whom the Head of Household of Origin Works Only on the Agricultural Sector.

\begin{tabular}{lccccccc}
\hline & \multicolumn{2}{c}{ Log (hyperbolic transformation) } & & \multicolumn{2}{c}{ Square Root } \\
\cline { 2 - 3 } \cline { 6 - 7 } & Transfers & Remittances & $\begin{array}{c}\text { Net } \\
\text { Transfers }\end{array}$ & & Transfers & Remittances \\
\hline Negative Rainfall SD: origin & -0.33 & $0.49^{* *}$ & $-0.90^{* * *}$ & & $-1.79^{*}$ & $1.40^{* * *}$ \\
& $(0.28)$ & $(0.19)$ & $(0.30)$ & & $(1.01)$ & $(0.46)$ \\
Negative Rainfall SD: destination & 0.35 & -0.27 & 0.47 & & 0.70 & -0.58 \\
& $(0.24)$ & $(0.24)$ & $(0.38)$ & & $(0.65)$ & $(0.44)$ \\
Outcome mean & 1.27 & 1.41 & & -0.26 & & 2.17 & 2.22 \\
Mean shock origin & 0.33 & 0.33 & 0.33 & & 0.33 & 0.33 \\
Mean shock destination & 0.13 & 0.13 & 0.13 & & 0.13 & 0.13 \\
Obs & 288 & 281 & 280 & & 288 & 281 \\
P-value: $\beta_{o}+\beta_{d}=0$ & 0.949 & 0.426 & 0.320 & & 0.175 & 0.092 \\
\hline
\end{tabular}

Notes: Negative Rainfall SD accounts for deviations of accumulated rain between June-July in 2009 from the historical mean divided by the standard deviation for each node multiplied by minus one. Positive values represent rainfall deficits with respect to the historical mean.

All regressions include household and individual level controls, regional fixed effects at origin and at destination, location controls and treatment controls.Dependent values inputed max and min values for the $1 \%$ highest and lowest outliers. Robust Standard errors, in parentheses, are clustered by comarca. ${ }^{*} \mathrm{p}<0.1,{ }^{* *} \mathrm{p}<0.05,{ }^{* * *} \mathrm{p}<0.01$ 


\section{Appendix: Migrants Selection}

Table C1: OLS: Impact of Weather Shocks on Probability to Migrate by Destination (15-21 years old)

\begin{tabular}{lcccc}
\hline & $\begin{array}{c}\text { Local } \\
\text { Migrants }\end{array}$ & $\begin{array}{c}\text { Non-Local } \\
\text { Migrants }\end{array}$ & $\begin{array}{c}\text { Ron-Local Migrants } \\
\text { Migrants }\end{array}$ & $\begin{array}{c}\text { Urban } \\
\text { Migrants }\end{array}$ \\
\hline Negative Rainfall SD: origin & 0.00 & 0.02 & -0.06 & 0.00 \\
Negative Rainfall SD: destination & $(0.01)$ & $(0.08)$ & $(0.05)$ & $(0.00)$ \\
& & -0.05 & 0.04 & \\
Outcome mean & & $(0.08)$ & $(0.06)$ & \\
Obs & 0.15 & 0.11 & 0.07 & 0.05 \\
\hline
\end{tabular}

Notes: Negative Rainfall SD accounts for deviations of accumulated rain between June-July in 2009 from the historical mean divided by the standard deviation for each node multiplied by minus one. Positive values represent rainfall deficits with respect to the historical mean. All regressions include household and individual level controls, regional fixed effects at origin and at destination, location controls and treatment controls. Robust Standard errors, in parentheses, are clustered by comarca. ${ }^{*} \mathrm{p}<0.1,{ }^{* *} \mathrm{p}<0.05,{ }^{* * *} \mathrm{p}<0.01$

Table C2: OLS: Impact of Rainfall Historical Variation on Probability to Migrate by Destination (15-21 years old)

\begin{tabular}{lcccc}
\hline & $\begin{array}{c}\text { Local } \\
\text { Migrants }\end{array}$ & $\begin{array}{c}\text { Non-Local } \\
\text { Nigrants }\end{array}$ & $\begin{array}{c}\text { Rural } \\
\text { Migrants }\end{array}$ & $\begin{array}{c}\text { Urban } \\
\text { Migrants }\end{array}$ \\
\hline Coef. Variation: orig & $0.10^{*}$ & 0.07 & -0.01 & 0.10 \\
Coef. Variation: dest & $(0.06)$ & $(0.14)$ & $(0.13)$ & $(0.08)$ \\
& & -0.00 & -0.03 & \\
Outcome mean & 0.15 & $(0.15)$ & $(0.15)$ & \\
Obs & 3464 & 3440 & 3440 & 3464 \\
\hline
\end{tabular}

Notes: Coefficient of Variation of accumulated rain between June-July from 2000 to 2009 at migrants' location of origin and of destination.CV $=\frac{\operatorname{STD}(00-09)}{\mathrm{MEAN}(00-09)}$ All regressions include household and individual level controls, regional fixed effects at origin and at destination, location controls and treatment controls. Robust Standard errors, in parentheses, are clustered by comarca. $*_{\mathrm{p}}<0.1$, ${ }^{* *} \mathrm{p}<0.05,{ }^{* * *} \mathrm{p}<0.01$ 